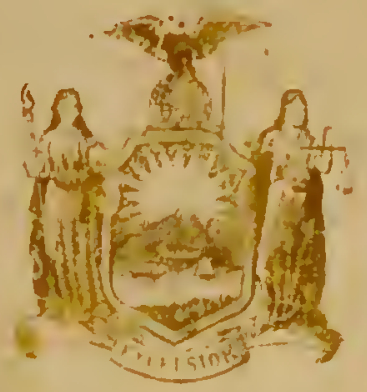

Dew York

at the

Sewis and Clark

Exposition

1905 
Cooper-Hewitt Museum Library

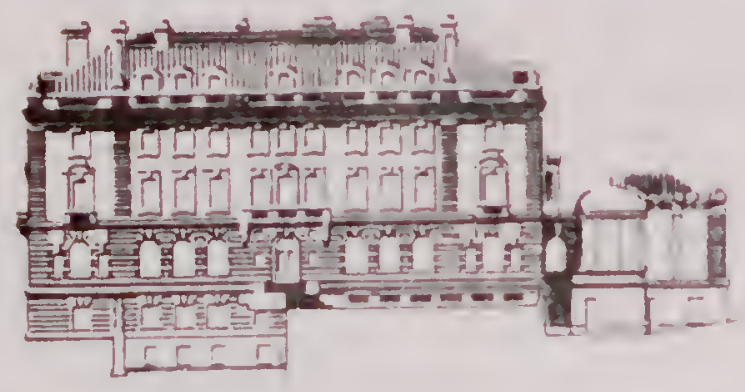

Smithsonian Institution Libraries 



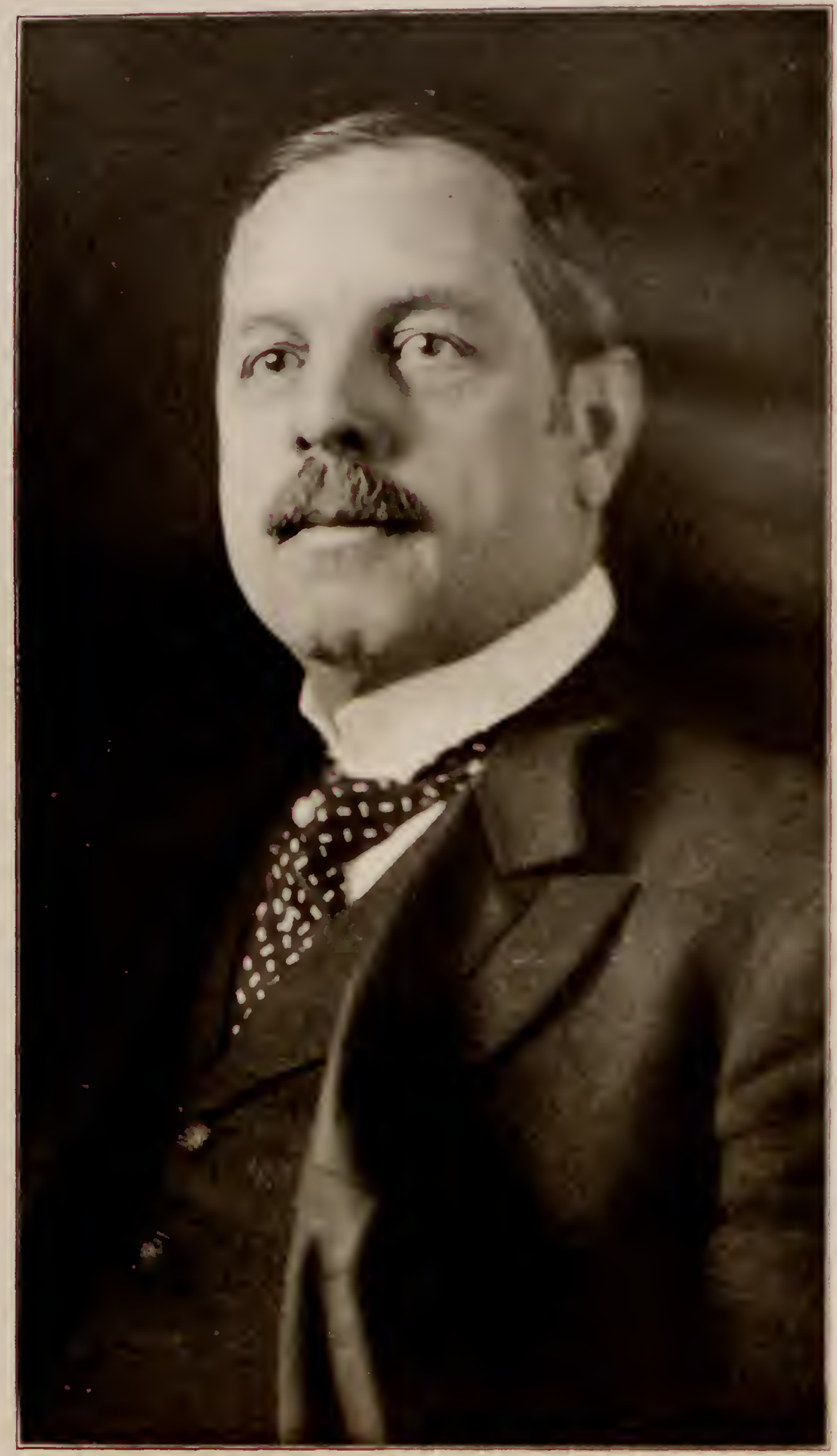

HUNURABLE FKANK W. HUGMINS Goverion 


\title{
Lewis and Clark Exposition
}

\author{
PORTLAND, OREGON \\ New York (state) Lewis and Clarkexposition carnmiserou \\ ㄴ \\ June I to October ${ }^{5}$, 1905
}

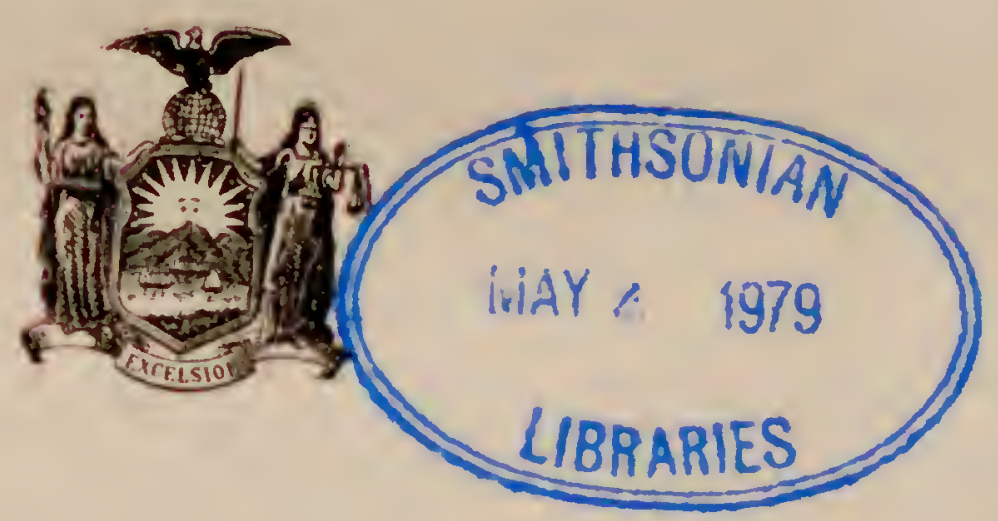

ALBANY, N. Y.

Brandow Printing Company

STATE LEGISLATIVE PRINTERS

1906

$s$

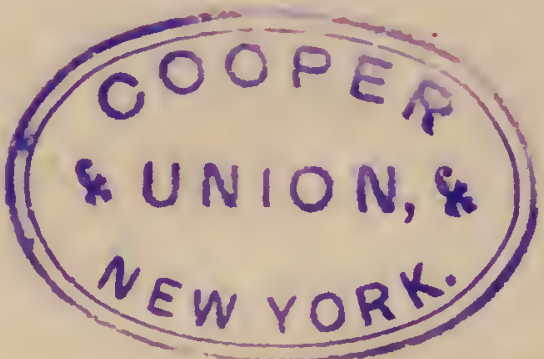


$2 \cos$

606

$775.32 . P_{3}$.

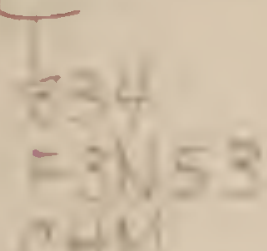

as 


\section{REPOR'T}

OF THE

\section{Lewis and Clark Exposition Commission}

OF THE

\section{State of New York}

$$
\text { Alinay, N. Y., May 1, } 1906 .
$$

Hon. Frank W. Higgins, Governor.

Dear Sir.-We beg to submit lerewith, in accordance with the provisions of the statute, the final report of the Lewis and Clark Exposition Commission of the State of New York.

Very respectully;

SAMUEL, B. WARD,

Cialience: JuUCe,

Hariry I). WILIAAMS,

P'RATT A. BROWN,

HENRY ALTMAN,

CHalils R. HUNTter. 


\section{REPORT}

\section{OF THE \\ Lewis and Clark Exposition Commission \\ OF THF}

State of New York

CHAPTER I. LEWIS ANI) CiARK EXPOSITION.

CHAPTER II. IEWIS ANI CiARK EXPOSITION COMMISSION, STATE of New York.

CHAP'TER II. New IORK STATE BuILDINg.

CHAP'TER IV. EXHiBIT.

CHAP'TER V. SOCIAL FVENTS.

CHAP'TER VI. NEW YoRK STATE DAY.

CHAP'IER VII. REception to New York S'TATE Society of Oregon.

CHAPliR VIII. Financiar Report. 

CHAP'TER I

Lewis and Clark Exposition 


\section{LEWIS ANI) CLARK EXPOSITION}

DHE Lewis and Clate Centemial Exposition held at Port-
land, (Mregon, flom .June 1 to October 15, 1905, will go down into history as one of the most successful ever mulertalien. It was sucecssful not only in the sense of untold valur both alucationally and commercially to the people of the Middlewest and Forthwest, but also in the thousands of peoplo from the Eastern states who eagerly aldiled fhemselres of the rely reasonable transcontinental ratlond lates. and made the Exposition their objective forint on a trip through the great West to acquaint themsclves with its magnificont proportions, its attrative scenery and its lemendons resonrces. 'The Exposition was also successful fonn a tinancial standpoint, laving made an astonishing rerorel in this respect and reflecting great credit upon those who mblninstrod its athairs. It is too early at this writing to state what peroutage is to be patid storkholelers, but it promises to be IIIIsHally lan?up.

()f late reals, subserightions are not made for exposition stock with the idea of reserving directly anything in return, but such subsoriptions ane invariably actuated cither hy civic pride or in Ixhalf of glviar or porporate interests outside the exposition

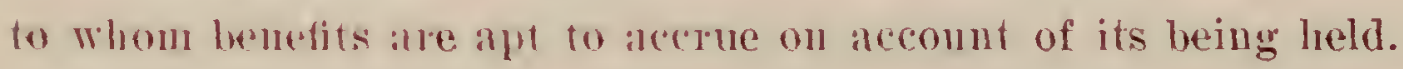
lt is idle, howerer, to endeavor to measure the value of any exposition in dollans and cents. Only to those who have been aremstomod to the atmosphere of such. and had the opportunity to observe the comutless risitols is their true value fully brought 


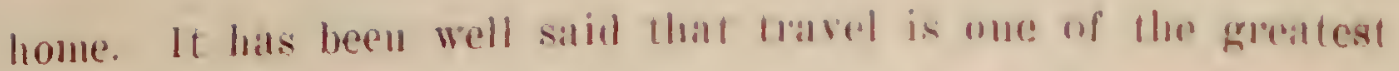
educational foress in the world. Sext to that must rome an exposition in mhich the industries. Hhe material resomres and

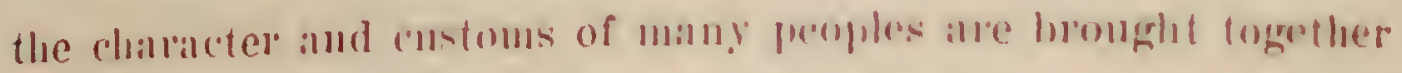

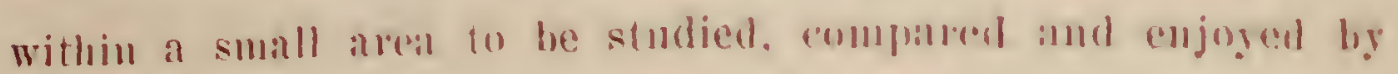
thousands of people whose resonrees momlst not permit of the

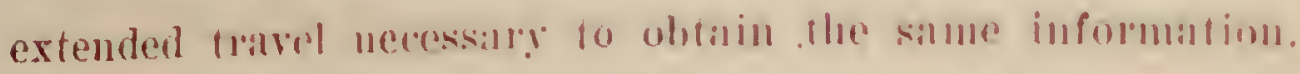

The tewis and clatk Exposition was held to commemorate thro

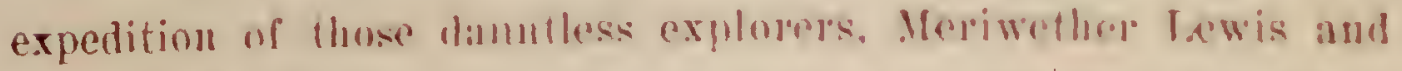

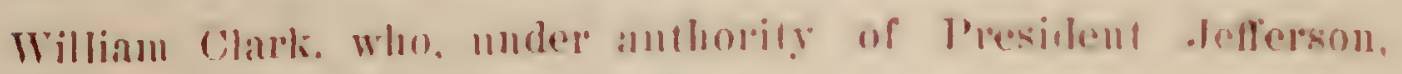

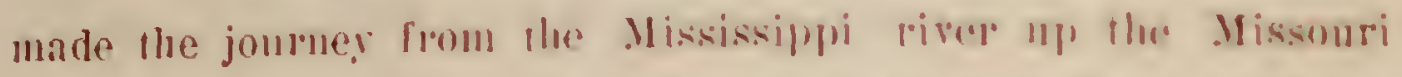

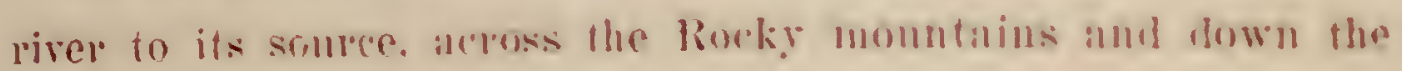
great Colmmbia to its mouth. as a rosmlt of which llue great Oregon countiy was opeued 11 to soplors. The expedition was

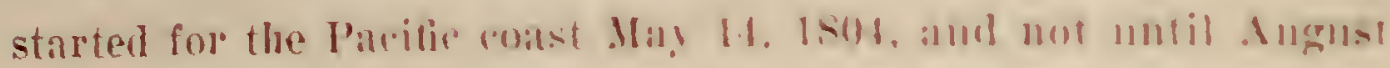

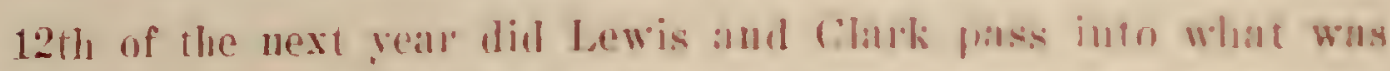

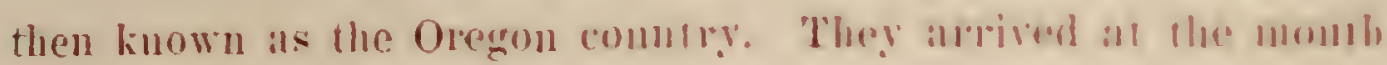

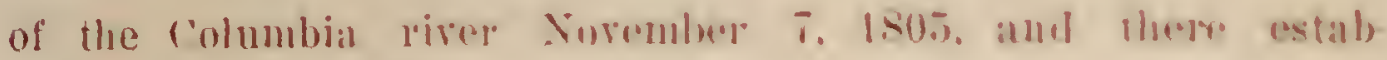

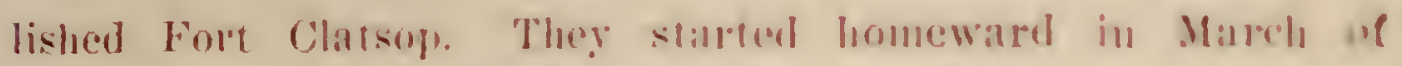

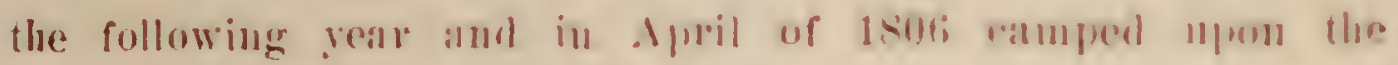

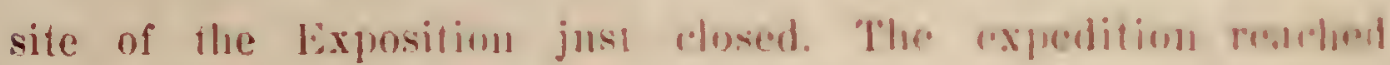
St. Lonis the following septembler. It was not morit June 15. 1S46, that a treaty betwen the l'nited silafes aud firma Britain was signed giving the linited filates full litle to the

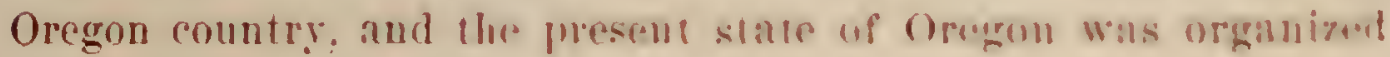
as a territory in Ingust. ISIS.

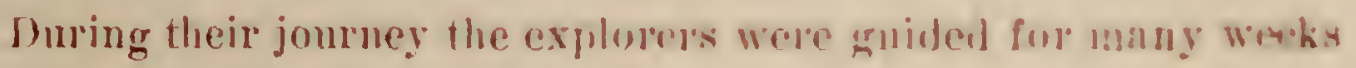

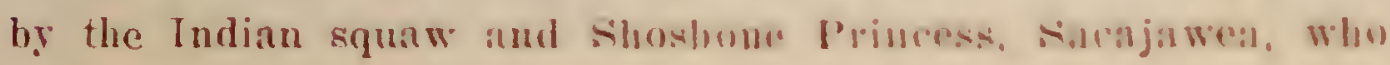
carpied her papoose upon her hate throughum thr joururgy and

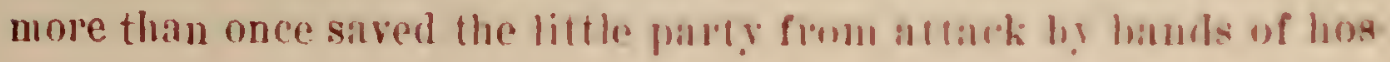




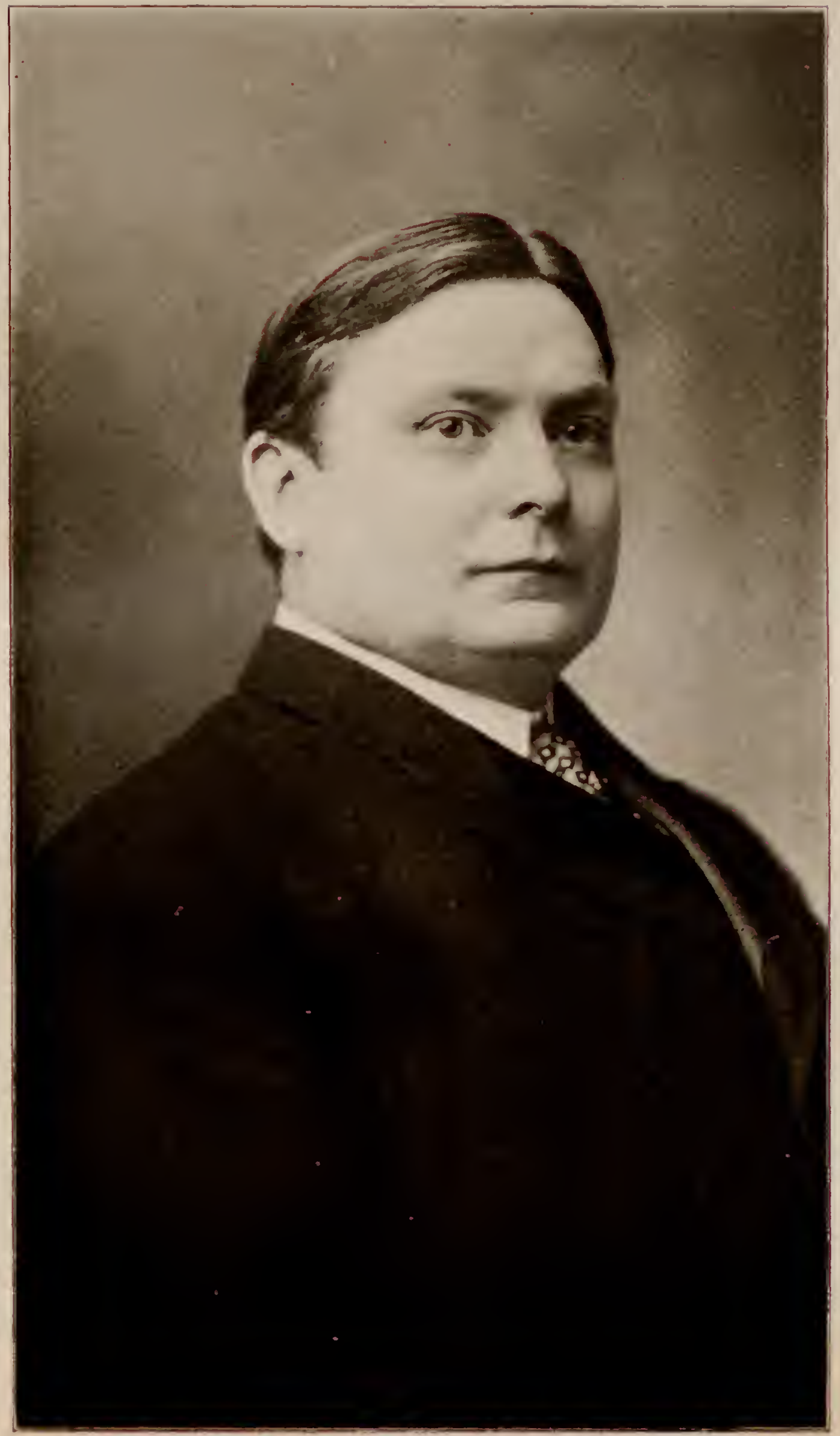

HONORABLE A. LINN BRLCE

LIETTENANT-GOVERNOB 


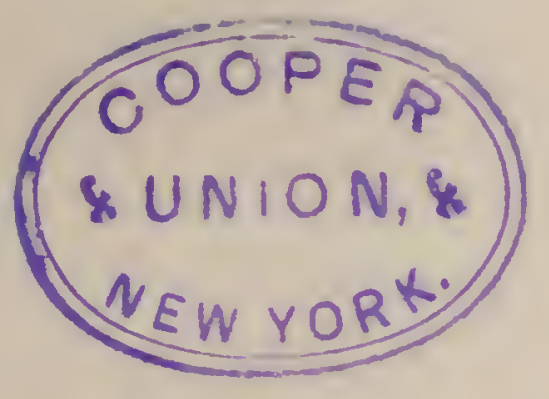


tile Indians. The naue Sacajawea (pronounced Sak-a-ja-wé-ah) was invariably linked with those of Jewis and Chark throughout the Exposition and especial honor accorded her memory. A magnificent brouze statue of heroic size, showing her pointing the way westward, was erected on the plaza at the head of the grand staircase. The statue was the work of Miss Alice Cooper, of Denver, the copper from which it was cast being donited by Dr. Hemry Wr. Coe of Portland. The metal for this purpose was originally intended to be provided by Colonel Henry Altman, of the New York Commission, from the Saluajawe crold and Copper Company's mines, of which company he is the president, located near Helena, Montana, but an mavodablo happening resulted in the honor falling to the first named gentleman. Funds necessary to conplete and erect the statue $(\$ 7,000)$ were raised by the Sacajawea statue Issociation. of which Ifrs. 1)ye was president, in the face of many diflicullies. but perseverance crowned their efforts with success, and on July bth the statue was unveiled with appro. priate and impressive ceremonies. It was flanked on either side by the statues of Meriwether Lewis, by Lopez, and William Clark, hy Ruckstuhl, which had oceupied prominent places in the st. Louis Exposition.

It was as long ago as November 1. 1895. that the idea of holding an exposition in commemoration of this great expedition was broached, and it is generally conceded that the credit for the sugrgestion belongs to Dauiel MeAllen, a prominent merchant of Portland. The idea did not prove popular at first, and no moneyed interests cane forward to back the scheme. It has been said that Mr. McAllen found himself in much the same position as an inventop who is unable to interest the public in his 
scheme, and like most inventors he was persistemt. but them the similarity ended, for he was erentually sucerssful.

The Oregon Bistorical socidy was the tirst henly to give the project its aid, recognimg that the crout to be rommemontat was one of striking importance in the history of Oregrom. After much preliminary discussion and agitatim, resolutions were

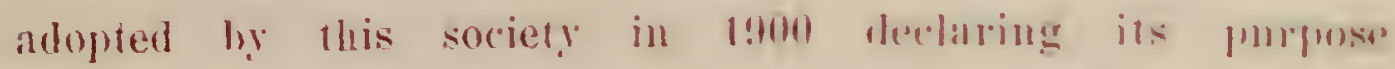

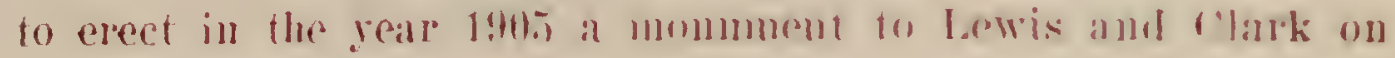
the site of old Fort Clatsoly. It was also restommemented in the

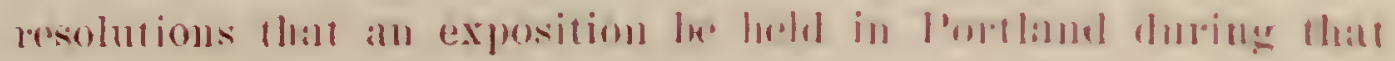

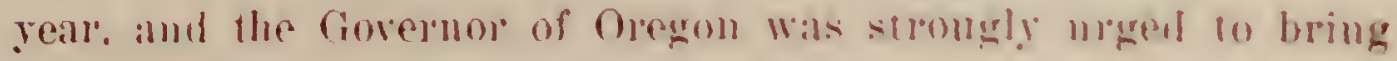
the matter before the next session of the Latristatme. Copies of the resolution were sent to neighhoring states, and a memorial Was sent to the Oregon delegation in comeress reppuesting them to urge national participation. In the meantime the ifea had been endorsed by the Yational Editorial Issociation. Whith at once insured a wile publicity to the flams of the sureitly.

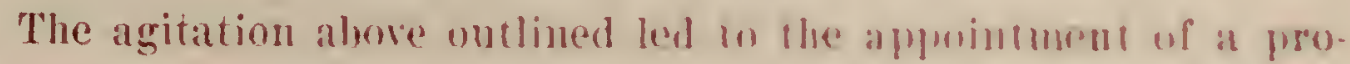
visional rommitter of twenty-one busiuess men of Forland in promote the Exposition, and on Fenmary 21, 1!)01, .1. .1. I.ong. chaiman of this committed. appratled before the Honse of Repre sentatives of Oregon mrging the passage of roncuprent resolutions in the Legislature endorsing the entermise and fledging fundeinl aid from the state. The resolutions were fumpulr adopted in

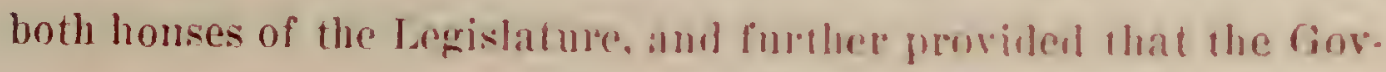
ernor should appoint five commissioners to represent the state and invite the other states of the lacific Xorthwest in whibit. Moreover, the National lomgress Wals mulussted m make an ap. propriation, and the resident was mperl to imite all foreigu

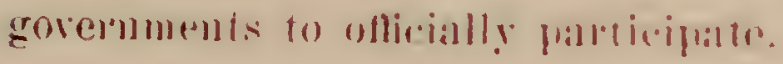


The Governol appointed the following Commission: Henry W. Corbett, Henry IA Anken!' Julge J. B. Bellinger, Senator C. W. Fulton and $\mathrm{F}$. F. Young. Commissioners were also appointed by the following states: Washington. Montana, Utah and Traho. and likewise by the Province of British Columbia. Many joint meetings were held at one of which the following name was adopted: "Tho l.ewis and Clark Centennial and Anerican and Pacific Exposition." Subsequently the words "and Oriental Fair" were aldeal in orlur to lake arvantage of a law whereby the city of Pontland could lery a lax in favor of an oriental fair.

Up to this fime all action, while important, was onle jure. liminary, and the first stejs looking toward the actual accomplishnent of the project were taken October 12, 1901, when a coppolation was formed to rarre it ont. The capital stork Was fixed at \$\$800.000 and the incorporators included a large mmmber of the most prominent hmsiness and professional men of Poltand. I commintee comsisting of the late Henry $\Pi$. Corbett. Samuel Connell and I. M. Long was appointed to open a stock book. In the cunvass they were assisted by a committee of thirty-five of the leading citizens of the city. No more striking demonstration of the enthusiasm and munimous support of l'ortland's citizens romld be made than in the fact that within two days smbscriptions to the antomt of $\$ 340,000$ had been secured. 'This meant practically st for each num, woman and child within city limits at that time.

The capital stock was shortly after incleased to $\$ 500,000$, practically all of which was paid in before the Exposition opened, and this sime liearfy enthusiasm and substantial support attended the Exposition thronghont its contire history. A liberal financial backing being assmeel. in . Tnully. 1902, a board of fifteen 
directors was elected. amb Henry W' cortrell wis rhosen presi. dent. The mumber of the horald of directors was increased in Ortober of the same rear to fuenty-tive.

Dnringr that summer the question of a sifo was formally takeus

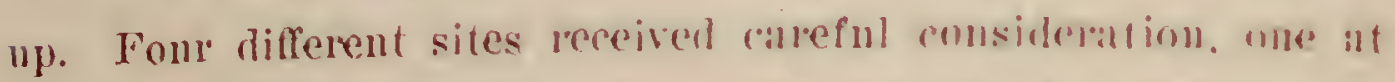

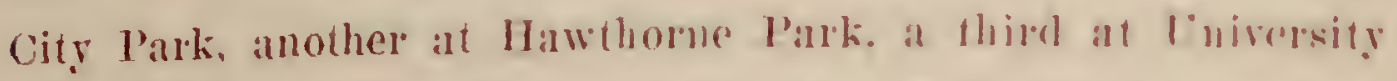
Park and a fourth at Willamette Heights. Taking info comsidera.

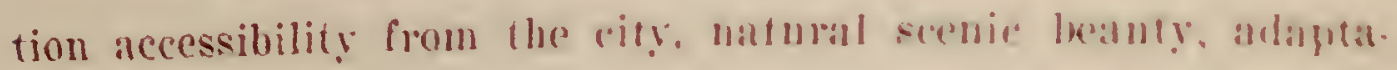
bility of the gromuds for exposition fmrpeses and matny ofler points, the Willanette Heights site was finally rolosent. combaniug 402 acres of land and lake neall the nothlowest limits of the reity and directly opposite the northemmost foint ratolued la lowis and Clark on their return jonrney in 1806 .

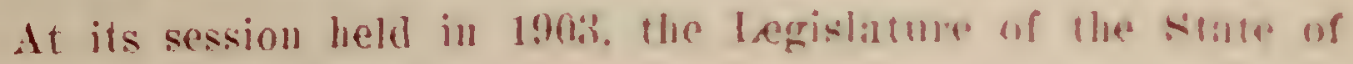
Oregon appropriated \$t50,000 for the farr. The an was signed

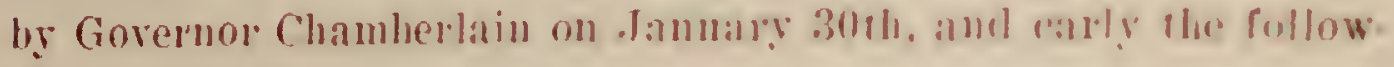

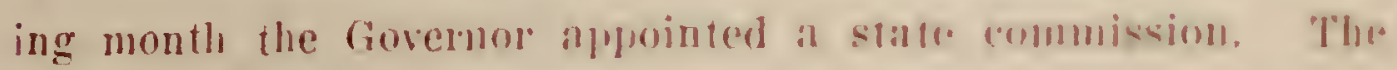
act undel which this commission was crealod rolhed it will rather extensive anfhority and plared it in a posifion similar to that of a United States rommissimn soming in an (rmpution held under the anspices of the Inited states forremuent. In other words. by the provisions of the law. While lle corporation previously formed was cother with the administration of the affairs of the Exposition. all of its acts affecting llu inferests of the people, such as classification of exhibits. rules goveruing

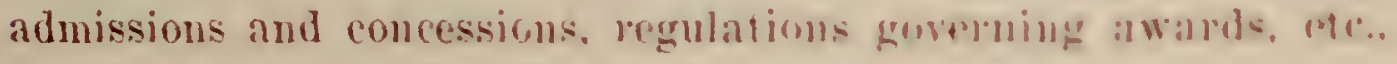
were subject to the approval of the sitar rommission.

The Governor appointed the followint commissinn: Iretorson Myers, Salem; W. L. Thomas, Jorthud: .1. H. Allert. Salem: C. B. Wade. Fendleton: Frank Willians. Ashand: R. V. Harry. 
Portland; F. A. Sipencer. Portland; Dr. David Raffety, Portland; J. C. Fhanders, Portlaud; Richard Scott, Milwankee; and E. E. Young, Eugene. The Commission met for organization in March, and later formally approved the site chosen by the board of directors of the corporation. The officers chosen were: President, Jefferson Myers; Vire-President, W. E. Thomas; Secretary, LAmund C. Giltner.

Up to this time, the preliminary work of carrying the project forward and placing it on a firm financial basis had been upon the shoulders of the Hon. Henry W. Corbett, who had made the first subscription of $\$ 30,000$ to the stock. He had worked unceasingly and cheerfully for the sucess of the enterprise, but it was not for him to carry it to a conchusion, as on March 31 st lie died, monrned by the entire commmnity and in fact the entire Northwest, in the development of which he had been so potent a factor.

The preliminary work of preparing the grounds was inaugurated with spring. The office of supervising architect with a board of consulting architects was provided for, and to John C. Olmstead, of Chicago, was infrusted the work of laying out the exposition grounds.

At the second anmul meeting of the stockholders held in June, the following Board of Directors was elected: H. W. Scott, I. N. Fleisehner: A. T. Mills, Samuel ('onnell, Slolph Wolfe, J. C. Ainsworth, G. W. Bates, A. Bush. Henry Ladd Corbett, J. M. Church, A. X. Derers. Ferdinand Inesser, W. D. Fenton, Leo Friede, charles E. Lalda. Rohert Livingstone, Dr. K. A. J. McKenzie, Rufns Mallory, W. W. Wheewright, W. W. Cotton, John O'shal. Jannes II. liuley, (i. W. Riddle, B. Vin Dusen and Paul Wessinger: Mr. Whalwright ant Mr. Cotton afterwards resigned and were succeded hy S. M. Mears and George T. Mrers. 
OOOPER

\& UNION. *

NEW YOR 
appropriating $\$ 475,000$ for a Govermment exhibit, all signs of pessimism at once disappeared, and the country cane to realize that the Lew is and Glatk fair was to be one of national inpoptance. A rigorous campaign of exploitation was at once inangurated which hought forth such fruits that the management were at a loss to provide space for those desiring to participate, and phans were immediately made to build an additional exhibit palace, and to provide additional gromud for the pavilions of states which later decided to participate. In only one way could the St. Lonis Exposition be sald to have been detrinental to the success of the fari, and that was that some states did not parliripate on areomit of hatring made such large appropriations for the Lomisiana P'nechase Lxposition, and othop states for the same reasm mado hut linited provision for the purpose. The net result was tholonghly satisfactory, howeres, laking all the cir('mlllstallors into consideration.

Besides the Emple state, the following statrs erected and mantaned stan bnildings: Oregon, Galiforuia. Washington, daho, Utah, Colobado. Hhinois, Missompi. Massachusetts and Mane. In addition. Hor following states and territories participated, althongh no state hulding was erected: Nebraska, North Dakota, Montana, Lonisiana. Wroming. Arizona and Oklahoma.

Maus plaborato and costly exhibits were sent inbat to Portland, and the Louisiana P'mbhase Exposition Company donated a munher of the finest groups of statuary which had adorned the grounds of the st. Lonis Fair. These were placed with mathed artistic skill and added wonderfulls to the embellishment of the grounds. The more promineut gromps inclnded "The Buffalo bance," which stood just west of the Xew lork luilding, "The storm." and the " lowhor at Rest," all the work of Borglum, 
"The Bull and congar." by Potter. "The Progress of Civilization," by - the fountains of Venus and Veptume, ly Philip Martiny, and last, but not least, the famous Remingrom gronp directly in front of and facing the main entrance " shouting nl) the Torn."

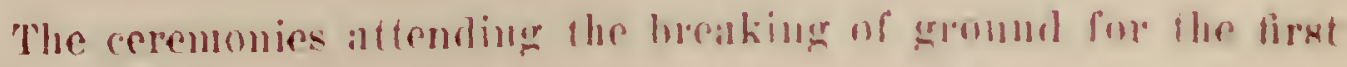
group of main buildings were held on April 7 , 1904. and from that day forth. The Exposition site was the scene of marrelons changes from day to day. The drealy waste of a few months before was invaded by an army of artisans and mechamics. and where weeds had thomrshed. beantiful lawns sprang up, marstres became submerged in a lake of shimmering bue. stately palaces pushed their towers amb minarets skrward, and shadred wallis and

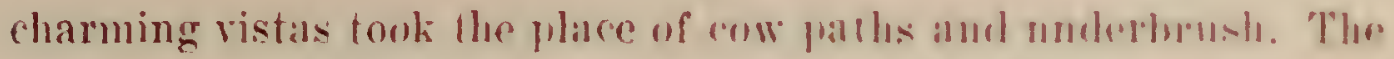
mild climate of Portland made it possible for lloe work to go forward unceasingly throughont the wintro and spring. and June 1st. the date set for the formal opening. foum arrything in shape for the reception of the ritr's guests.

No exposition was ever honored with the ghesente of more dis. tinguished guests upon its oprening day than was the low is and Clark Fair. The Vice President of the loniter states. Hon.

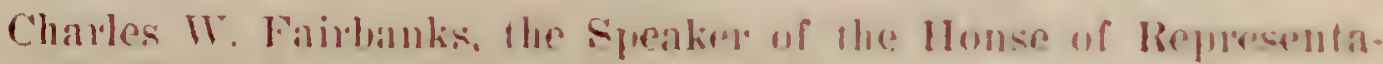

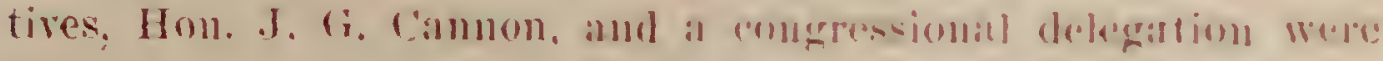
present, as were the bovernors of fire states. atfonded lis their staffs. Although win had been falling for mang days and far into the night preseding June Ist. sun shone throughont the day and the fair opened under most anspicions conditions The rice-President and ronglessional delogition arribed at Portand the day before the oproling. and flue formep was the guest of President foode dmong his star. I military parale 
was held in the morning, starting in the heart of the business portion of the rity at ten o'clork, and malrobing to the fairgrounds. The Fondeputh Regiment of Infantry from Vanconver Barracks, the Tenth Cavaliy from Fort Walla Walla, several regiments of the Oregon National Guard, and many eivic organizations took part in the parade which acted as an escort to the Vire-President and his partr.

The New York state milding played a comspicuons part in the opening day reemomies, as it invalrably did with nearly all of the oflecial functions connected with the Exposition, as will he hereafter recorded. Flre parade entered the gromuds at the

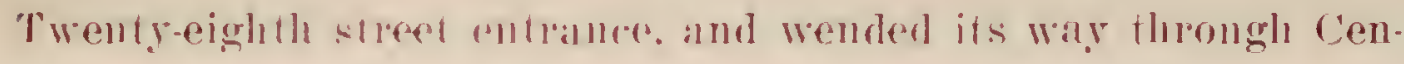

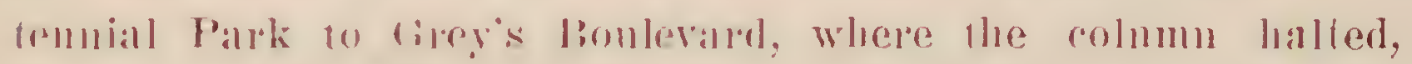
wheeled into line. presented ams and hie honored gnests were driven past to the steps of the New York bulding, where they alighted and retiond to the cool reception pooms before taking their places upon the speaker's stand whinh hat heen erected mom the plaza at the hearl of the grand stalirase.

The exereises were lield at wolve oblock nom, and the fol lowing progran was arried ont: Vice-residential salute, nineteen guns, hy the Sixtrenth Rattery, United states Artillery; musir. Festival Mareh. Innes band; invocation, Bishop David H. Moore: mosice. Tmperial Orenom. ly Innes band; address. lresident II. W. Gonde: address. Governor George E. chamberlain, of Oregon; address, Hon. Jefferson . Myers, President Oregon State Commission: address. Fon. Cororge H. Williams, Mafor of Portland: address. Hon. Slatence H. Slark. I'. S. Senator of Wroming; address. Hom, dames A. Tawney, Member of congress. Minnesota; address, Hon. H. A. Taylor. First Assistant Secretary of the Treasury: aduress. Hon. Joseph r. lannon. Speaker 


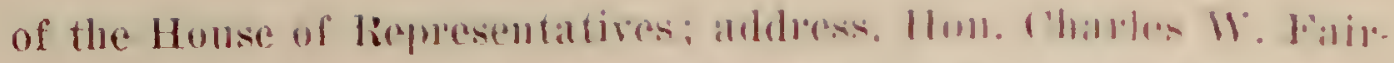

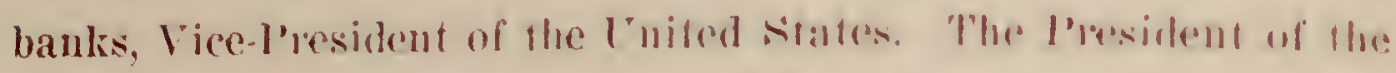
United States was then moritied in Wishingtum hy means of a special wire comnected from the spreaker's stimbl diredly for the White House that all was in realiness for the formal unening.

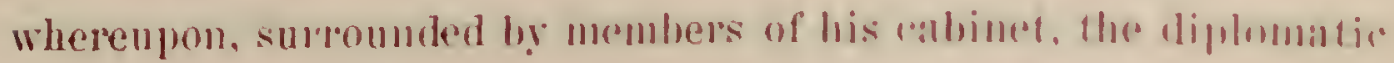

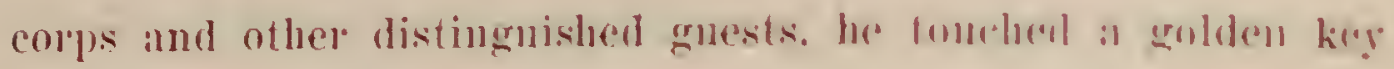

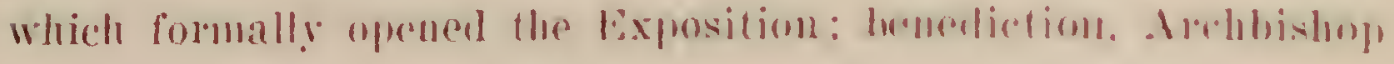
Alexander Christie.

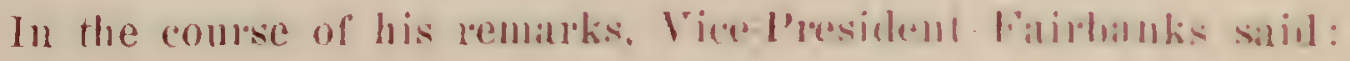

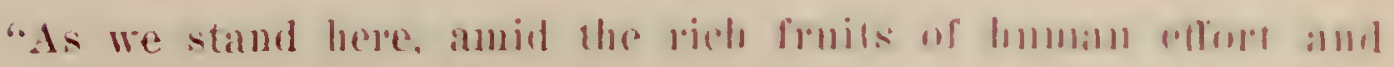

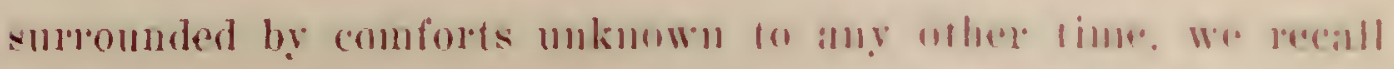
with momeasured appreciation the pioneress who leal the waly ro

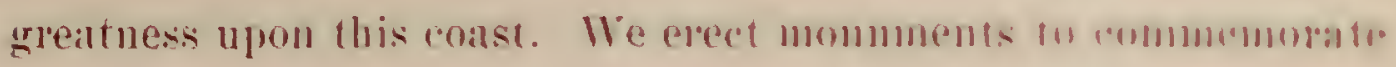

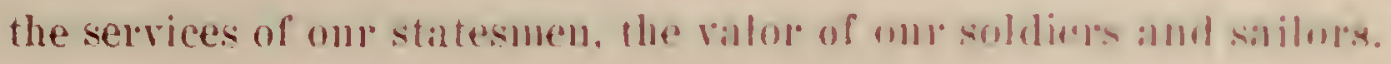

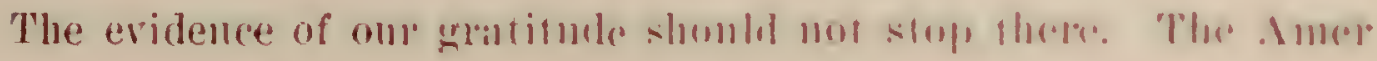

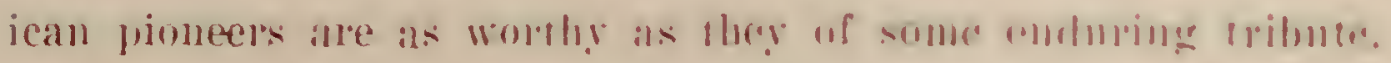

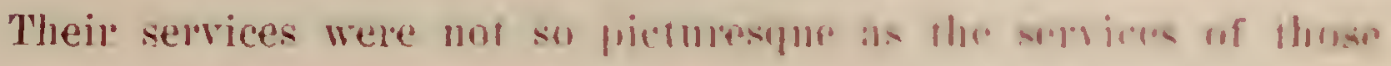

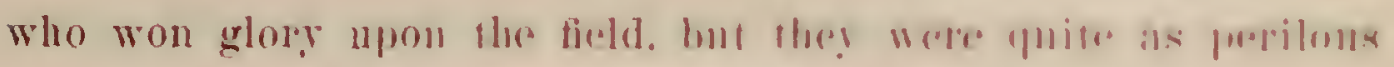

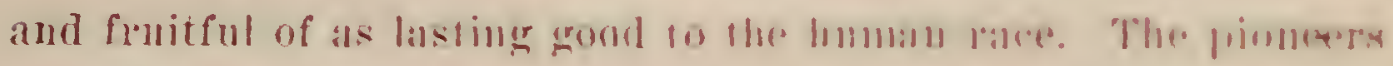
were, indeed, soldiers-soldien's in the almy of peatr. They wor

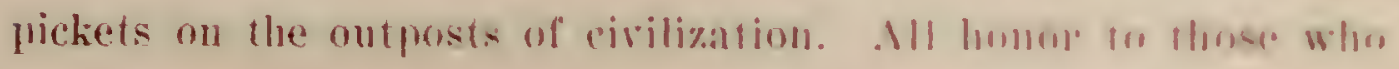

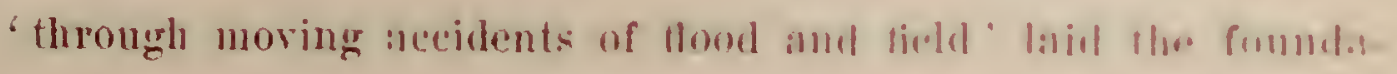

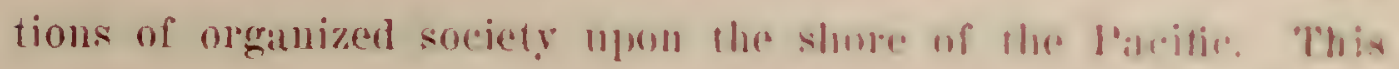

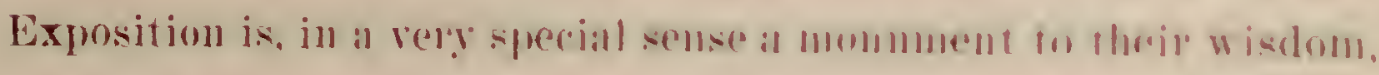
their virtue and their fortitude. " " Som halue made and

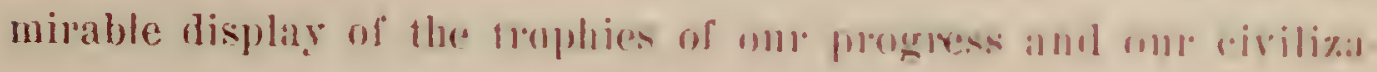
tion. No American can look npon what is here presenterl withoms increased admilation of his rommtryment, and no foreigner who

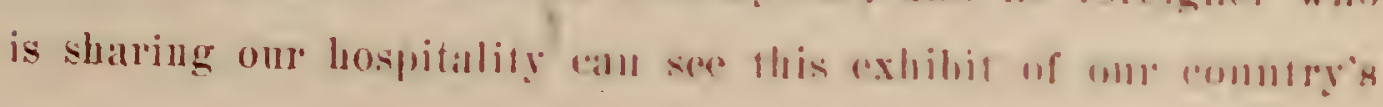


development without marveling at the resonrefuluess and virility of the new people who have attained a giant's strength, but who seek to nse it only in promoting the priceless arts of peace. The foundation of om highest and hest development is not to be found in nature:s illimitable wealth, lut in the observance of the orderly processes of the law and the pratice of those virtues which are the cornerstone of the home. and which are the strength of the state-its sme stay in the hom of strain and stress. We are assembled from remote neighborhoods. yet we are in "lose touch and sympatly. We are bomd together in the everlasting bonds of national afferetion and mational mity. One wation's lonor is

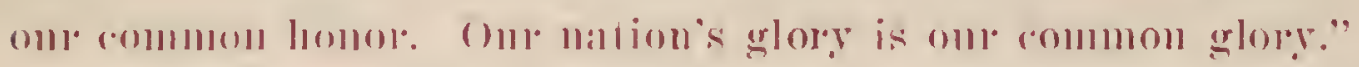

At the rondelnsion of the exereises, the congressional party and distingnished gruests adjombed to the Sew York state building as the guests of the bxposition management, where lumch was served. The afternoon was deroted to sightseeing and at half past seven a dinuer was temdered Vire-Pesident Fabloanks by Ipresident Goode al the New lork building to which some 250 guests were bidden. Tables were set both npou the voranda overlooking the lake and in the dining roon adjoining. There was an dabolate display of fireworks and shorlly after nine

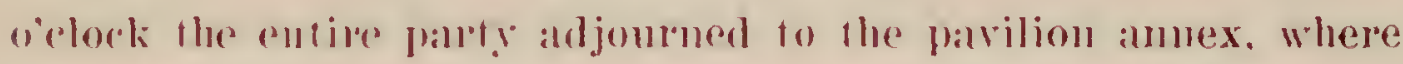

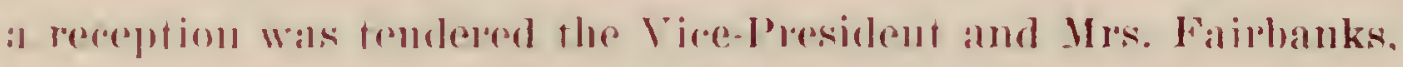
at Whicls were present about $\ddot{2}, 000$ gnests, including the Congressional delegation, visiting Governors and their statis, the Board of Directors of the Exposition, state and Foreign Commissioners and many prominent Portland people.

And thus the lixposition was lannched upon its brief career of fom and one-half mouths, a career marked by no untoward event of comsegueme. Folvored by one of the most delightful 


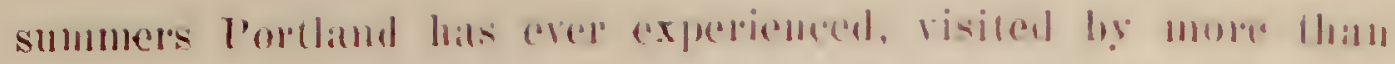

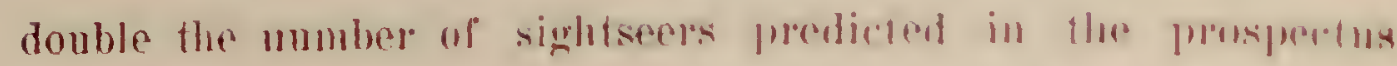

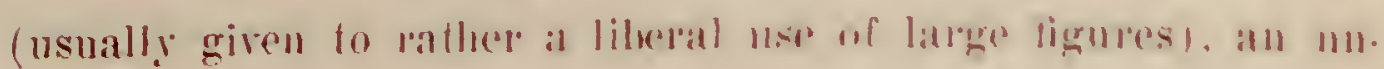
qualified artistic; edncational and fimamrial smoress. if will mank an epoch in the development of the ergeat Ximblawest. and for the next half century the reall 1905 will he lle froim flom which all dironological computations are reclioneal.

A wold as to the suceess of Presirlent fomble in grabling llate

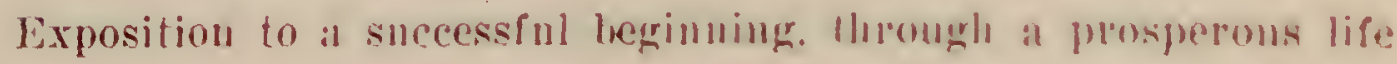
and to a glorions finish. certainl! wambl mot be out of place in this report. A man of sterling integrily. strong willail, self. reliant. absolntely just and unifommly rometemus, he diroved the multitude of affairs with an merring landrd. and as the seope of the project grew and additional drmands were made npon

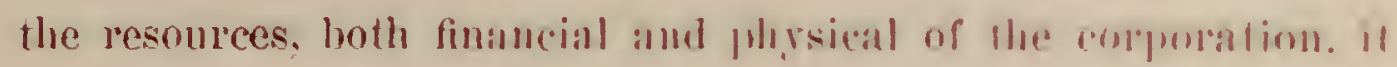

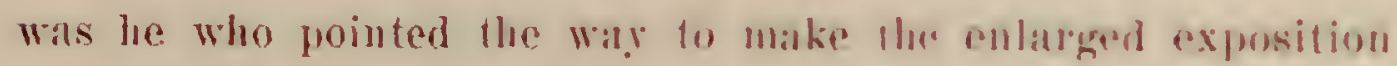

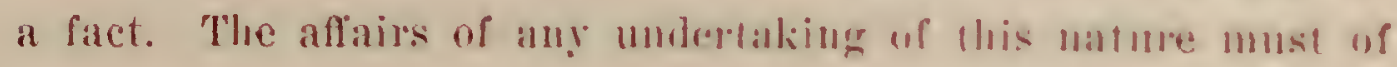
necessit! he directed by a simgla individual. "The lorevily uf time

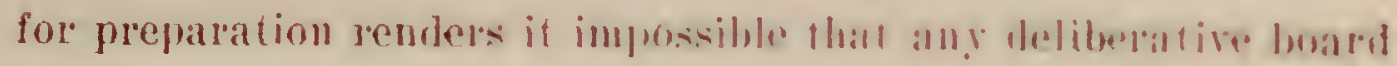

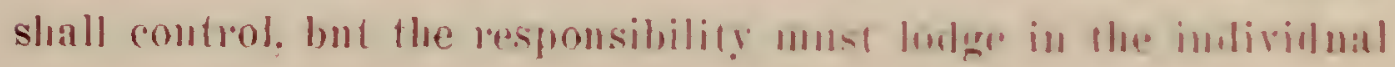

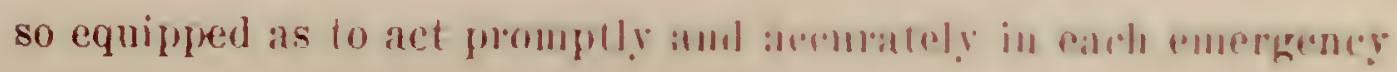
which alises.

President Goode inaugurated his work will the full cunfidence of the Board of Directors and llem lumsiness interests of l'ort. land generally. He closed il will a loust of fromels throughout the civilized world who have lealuel fu almire his rapacity for work and to appreciate the absolute impartiality whll which lo

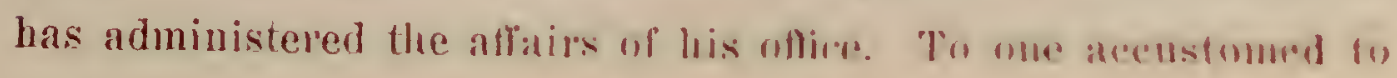
exposition frocedme. it was a maller of mole lhall llac adminialra.

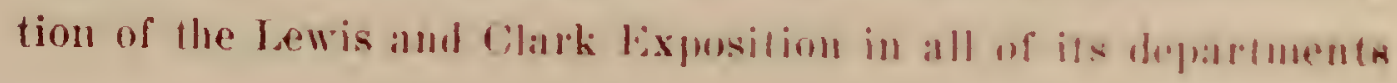


was absolutely shorn of superfhous forms and red tape, which in many expositions have been enforced to the annoyance and inconvenience of participants, in order to meet a few scattering instances of almse of privileges. There was a marked directness of dealing which indicated a hearty desire to favor the interests and render nore agreeable the stay of those who took part in the Exposition. Throughout the period of the Exposition, each day bronght many diverse demands upon its president, and notwithstanding large personal interests, President.Goode met each engagement, whelher business or social, with equanimity and tact. Few realize the difficulties which beset a man directing an exposition, and some are prone to criticize on account of pelty error's, forgetting entirely the much larger and important result, the splendid benefits from an educational standpoint which are bound to follow.

President fioodes ripe jndgment was perhaps best shown in the appointments of the members of his official family, each one of which rontributed in no sintll way to the perfection of the ensemble. The Director of IIorks, Mr. Oskar Huber, a civil engineer by profession lut an artist by birth, made the most of his opportunities in producing landscape effects that wil! linger long in the memory of Exposition visitors, and moreover be it said to his credit that, notwithstanding the tremendous crowds, and lack of rain thromgh the summer, the grounds were at no time in better order than dnring the closing week.

The Director of Architecture, Mr. Ion lewis, brought his skilful judgment into play in the graceful grouping of the buildings and in the modification of plaus of structures so as best to produce an harmonious whole.

No further testhonial need be paid to the secretary. Mr. Henry 
E. Reed, who was also Direetor of Exphoitation than lo point to the record of attentance. The effordirentess of his work is abso. lntely proven therein.

Col. Henry E. Dosch, the Hirretor of lixhibits. amb tohn $\mathrm{A}$ Waketieh, the Director of Admissions and Concessions, hoth brought to the Portland Fair ripe knowledge of exposilion frop. cedure gained in several experiences in mprons expositions.

Mr. Theodore Hardee. Assistant to the President. amb Major

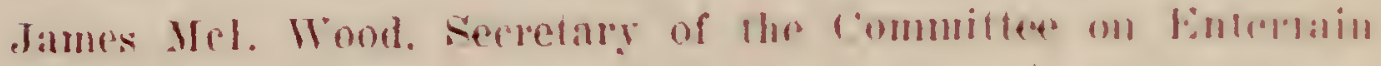
ment, were charged with providing for the comfort and fulatsuse of distinguished gruests. This duty was performed with lignity and tact.

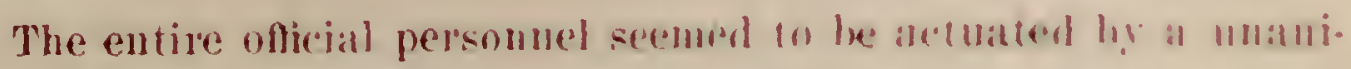
mous desire to produce the best resuls and was possensted of an esprit de romps but seldon found in an orgatnimation of a tempur rary nature. 
CHAP'TER II

\section{Lewis and Clark Exposition Com- mission, State of New York}





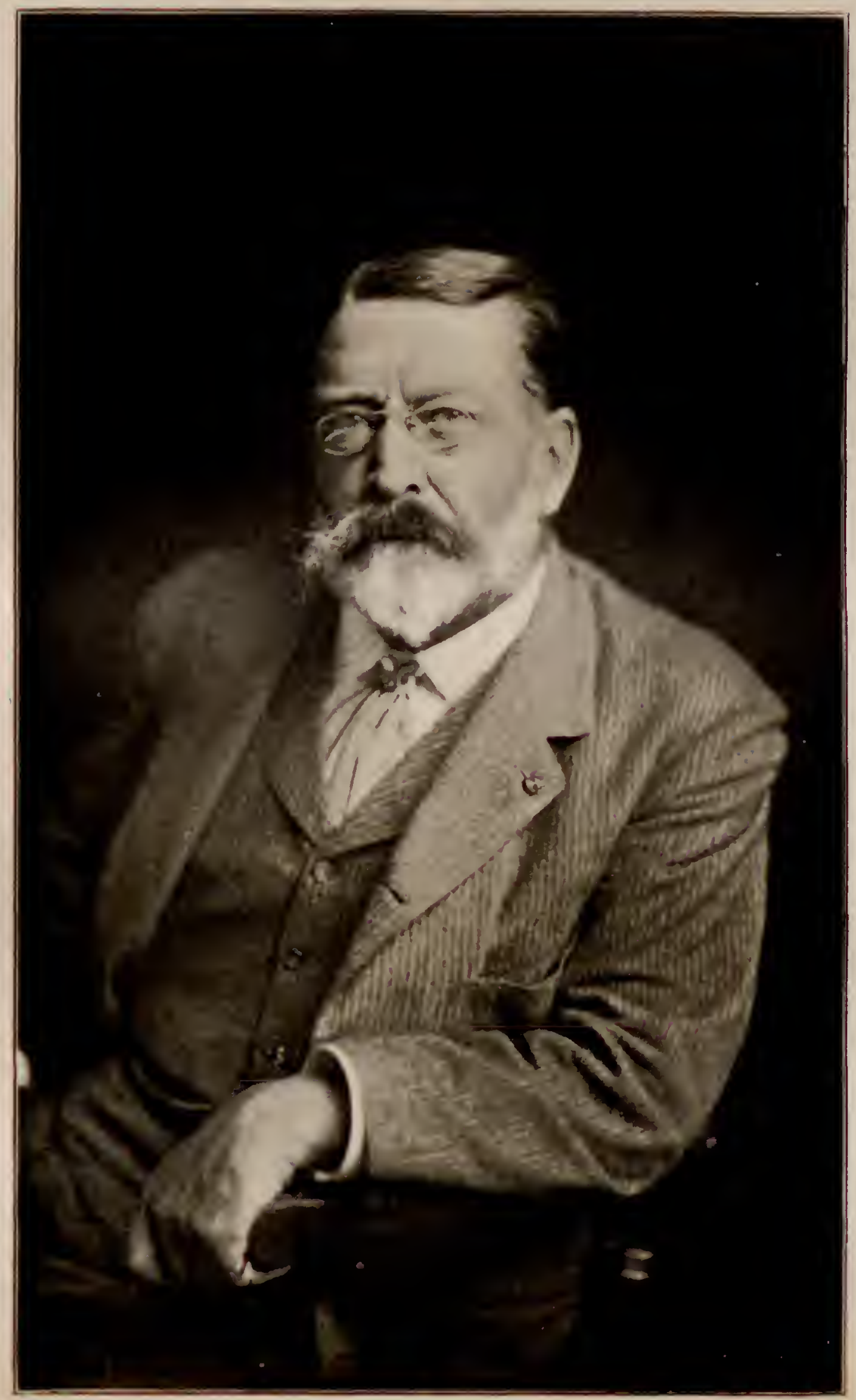

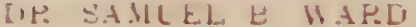

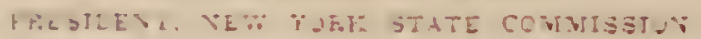




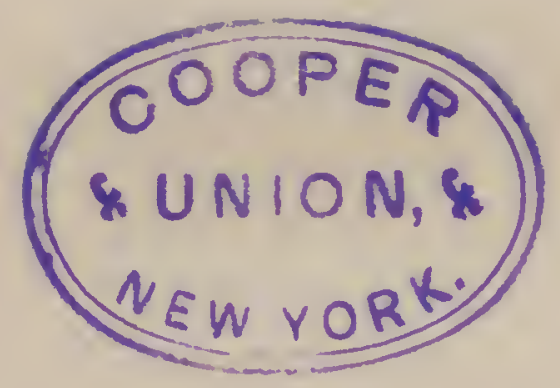




\section{LEWIS AND CLARK EXPOSITION CON- MISSION, S'TATE OF NEW YORK}

I response to mgent invitations on the part of the bewis and

1 Clark kxposition Company, and to a decidedly lavorable pub. lic sentiment. the legislature determined that the state should participate in the Lew is and Clark Exposition, and the following item was inserted in the anmul supply bill, which became chaptel. 729. laws of 1904 :

"For the Governor, for the purpose of providing for" an exhibit by the state of New York at the Lewis and Clark Centennial Lxposition to be held at Portland, Oregon, during the year nineteen hundred tive, including expense of transportation to Portland, Oregon, and retmm therefrom of so much of the exhibit to be made by the state at the Louisiana Purchase Exposition as he may deem to be appropriate, thirty-five thousand dollars $(\$ 35,000)$, or so much thereof as may be necessatry."

In the fall of 1904, Governor Odell named as at commission to carry ont the provisions of the above act: Frederick R. Green, of Fredonia; Mr. Samuel L. Ward, of Albany; Clarence Luce, of New York Gily; Hary I). Williams, of Buffalo; Pratt A. Brown, of New York Gity; Hem! Mltman, of New York City, and W. H. King. of New Fork (ity. Shortly after, Mr'. King resigned, and Charles R. Huntley, of Buffalo, was appointed in his stead.

P'ursuant to a call issued by the Governor. the Commission met for organiation in the executive chanber all the Capitol at 


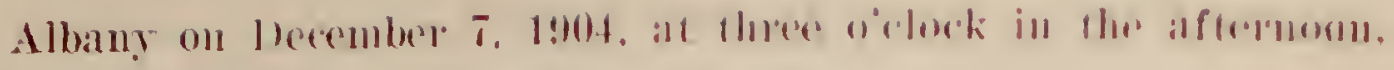
and completed its organization as fullows:

President-Frederick R. Firen.

Vice-President-Dr. Simmel I: Wald.

Secretary mo tem-Clanence 1.m\%\%.

'Treasurel-Harly D. Williams.

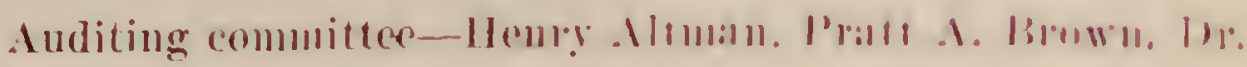
Samuel 13. Warr.

The following hy-laws were adopted:

"First-The onicers of the lowis and clatk lixpusinon Commission, of the sitate of New lomk, shall eonsist of a foresi dent, vice-president, lreassmer and speretaly.

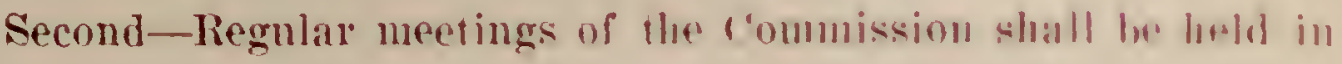

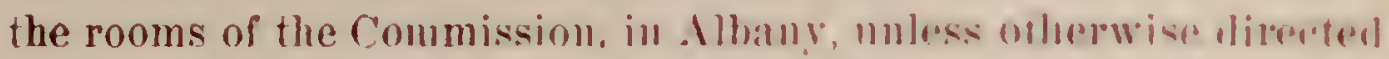

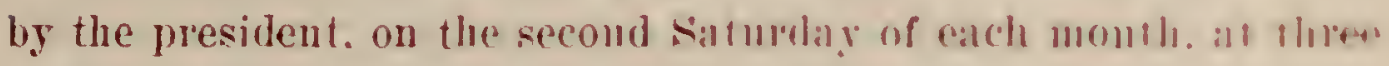

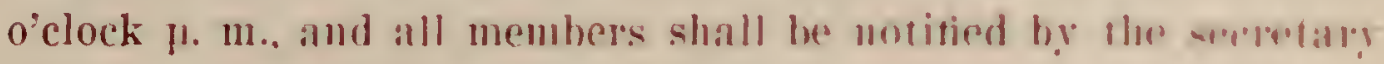
one week in advance of such meetimg.

Third-Three members of lle fommistom shall fomslifuld : quorum at all regular meerings.

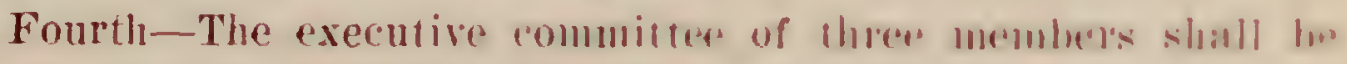
appointed by the mesirlent, who shall designate irs Marmun. who shall also act as chaiman at lle mextings of the fommis sion in the absence of the fresident or virepresident. Flu exrent

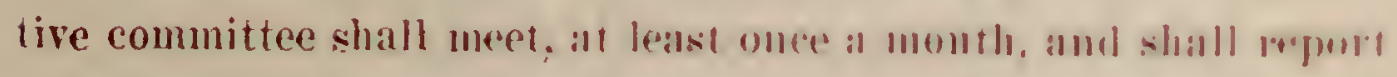
at the regular meeting of the lommissinn. "Twe mentrers of the

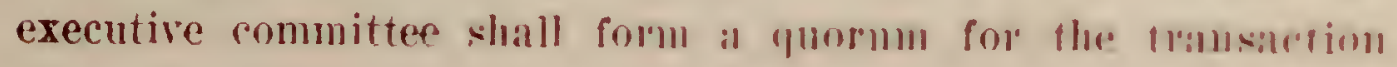
of business.

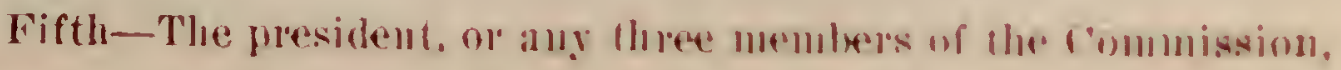
may eall for a special meeting though the sermotily, of the entire Commission, at am! lime. hy giving one wreks molier. 
Sixth--There shall be an anditimg committee of three nembers whose doly it shall be to examine and andit all bills and accounts (the action of any two being binding) and report al the regular monthly meetings of the Commission.

Serenth-A treasmer shall be appointed by lle Commission, who shall bay all hills which hare herell moplerly rertified by the allelilimg rommitlees.

lighth-Plie oldel of husiness at monthly meetings shall be as lollows :

3. Realing of minuter of previons meeting.

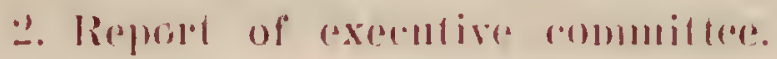

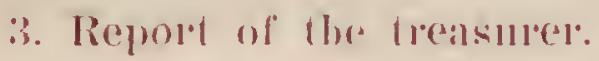

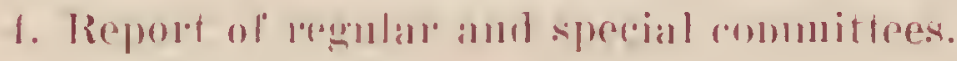

万. Intinished husiness.

6. Coll111110 ations.

7. New business.

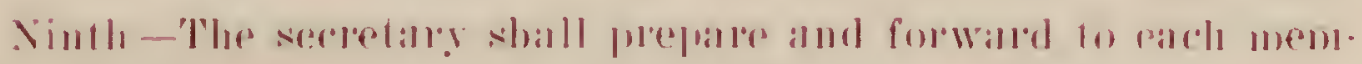
her of the ('ommission a ropy of the procedings of the previous mostimg in his rogular monthly calls lol meetings. The secrefaly shall be in constant affendance in the rooms of the Com-

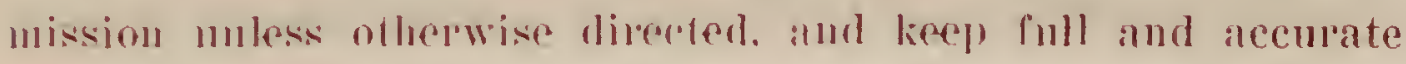

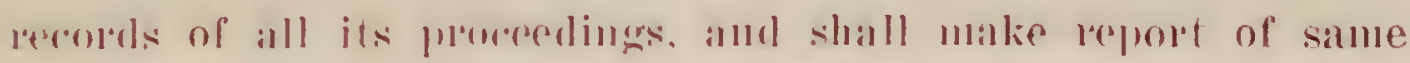
from time to lime as he may he bequired.

Ill his records shall be open al all times to the inspection of any member of the commission.

Ho shall perform surb dufies as the president of the Commis.

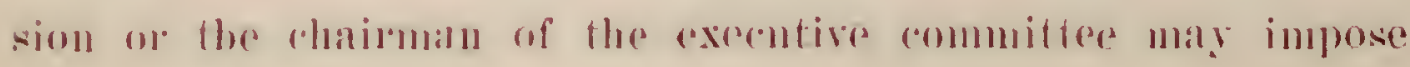
"1)!l hill."

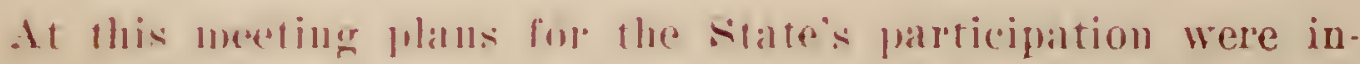
formally discossem, and the following telegram was forwarded 
to DeLancer II. Ellis, then the Director of Eduration and Social

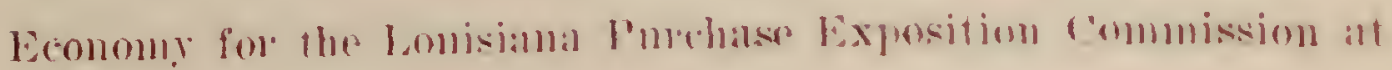
St. Lonis: "The Oregon Commission desire you to take possession for them of such exhibits mentioned in the resolution of the st. Lonis commission as you may think available. Iaftep fo follow. (Signed) F. R. Green. Presidrull."

Pmsuant in these instructions the following statm exhithits

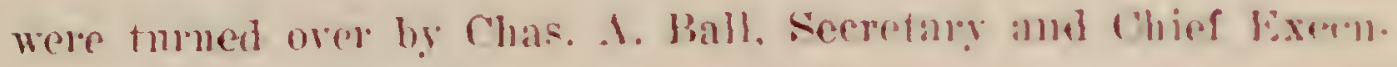
tive Ofticer of the Lomisiana Purehase lixposition rommission. to Mr. Ellis-the entive exhibit in edncation and sncial prommus. a part of the forest. fist and game exhibit. also palts of the agricultuml and scientific exhibits. These were stomed in the Handlan Co.'s warehouses in st. Lonis pending the enmpletion

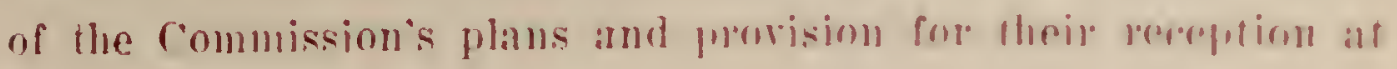
P'ortland.

The second merting of the Commision was lish an the Hotel Ten Eyck. Albany, on .January 1. 190\%. It that time a general informal discussion was had concerning the prertion of a sitate building. the plan and scope of the state exhibit and the wayk and means for carrying on the work. It was the collowsus of opinion that an additional appropriation wernlat he absolutely necessary to enable the state to participate in the fixposition in a manner commensmate with its lignity and importaner, and that it wonld he impossible for thr commiscion on mphold the States prestige at an exposition so far from lume npon the amount then avalable for the murpose. Therrefore it was decided

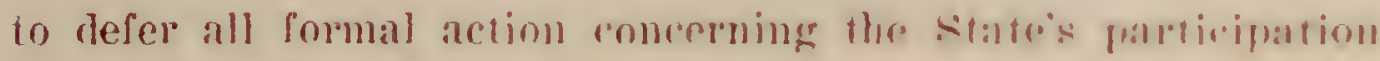
nutil a later meeting. and in the meantime (1) nas strennons

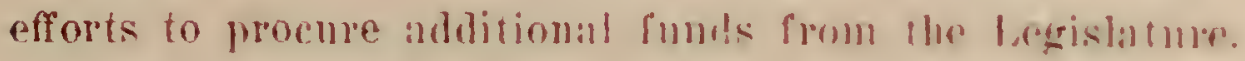


Inasmuch as the appropriation lrad been made directly to the Governor, he requested that a bill be presented to the Legislature transferring the appropriation from the Governor to the Commission. This act was introduced and shortly after passed and became chapter 715 , laws of 1905 , and is as follows:

\section{CHAP. 715}

AN AC'T to movide fol the representation of the state of New York at the Iewis and Clark centennial exposition, at Portland, Oregon, and reappropriating money heretofore appropriated for such purpose.

Became a law, June 3, 1905, with the approval of the Governor. Passed, three-fifths being present.

The People of the Stute of New York. represented in Senate and Assmbly. do enact as follows:

Sulion 1. Frederick R. Gren, simmel B. Ward, Henry ditman, Pratt A. Brown, Claremce lunce, Charles R. Huntley and Harry D. Willians, lrevetofore appointed by the governor, in pursnance of daptel seven lrundred and twenty-nine of the laws of nineteen hundred and four. for the purpose of providing for an exhibit by the state of New York at the Lewis and Clark centennial exposition to be held at Portland, Oregon during the rear nimeteen hundred and five, are hereby constituted a commission to be known as the "lewis and Clark exposition rommission." such rommission shall encourage and promote an exhihit of the rommercial, edncational, irrustrial, artistie and other interests of the state and its citizens at snch exposition, and shall if it deems advisable provide. furnish and maintain, duriug the exposition, a building or room for a state exlibit and for the oflicial headquarters of the state, for the comfort and convenience of its citizens and exhibitors. Snch exhibit shall include so much of the exhihit made by the state of New York at the Lonisiana purhase exposition. as the commission deems advisahe. Surle commission slrall have powel and anthority, in 
its discretion, to sell ol otherwise dispose of an! bmilding. lindu.

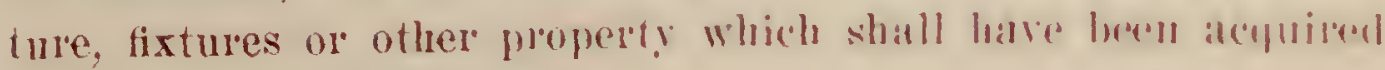
by it pursuant to this section.

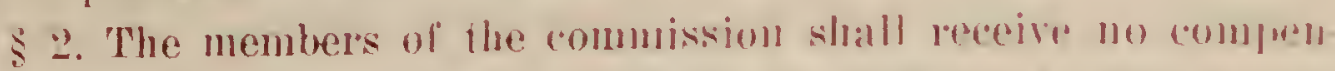
sation for their servies. but shall be potitled to the actual necessary expenses incured while in the discharene of their dulius.

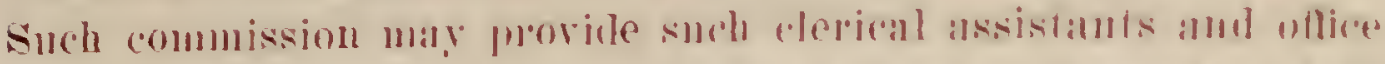

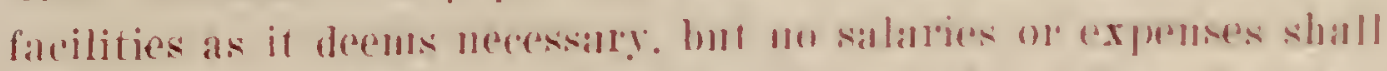

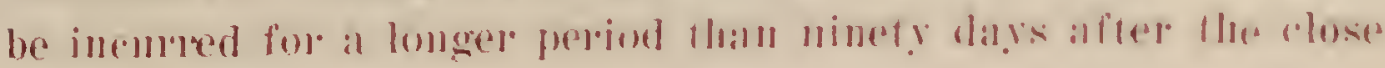
of the exposition.

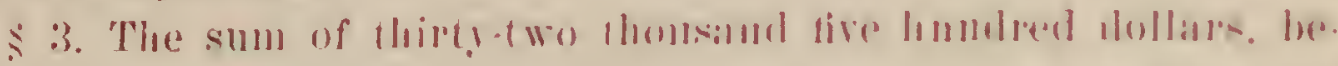

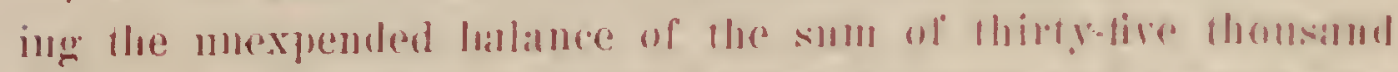

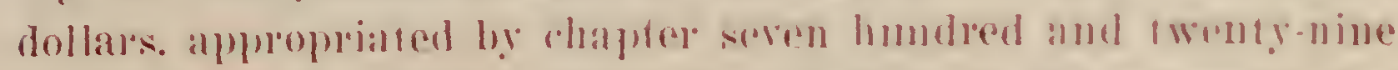

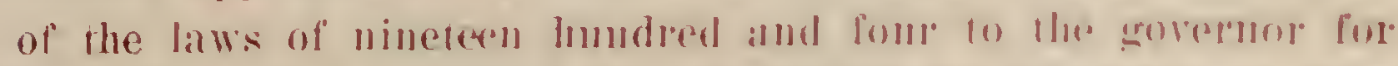

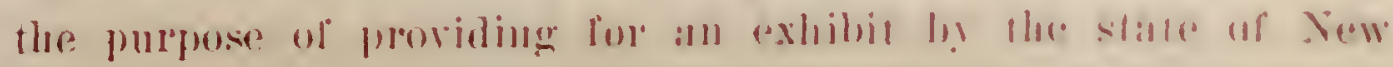

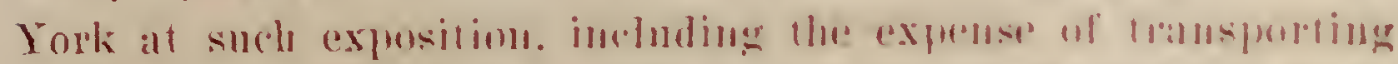

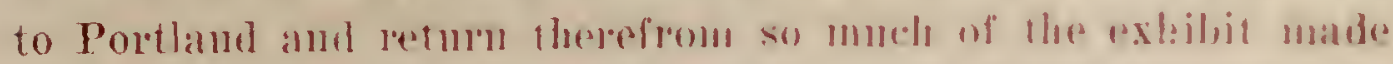

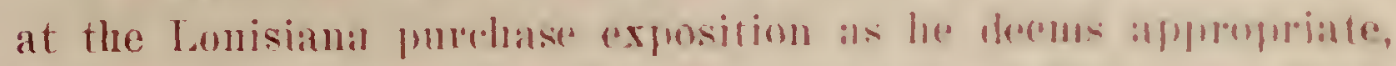

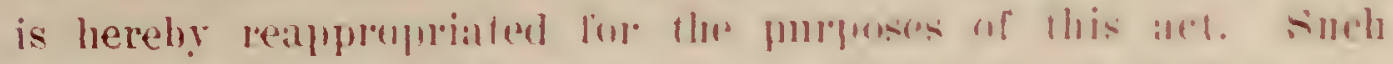

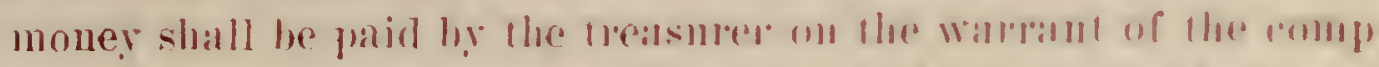

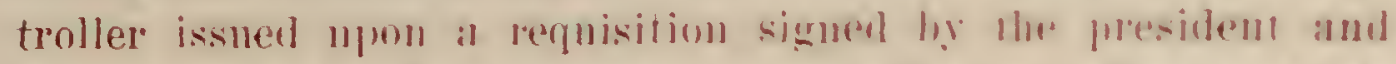

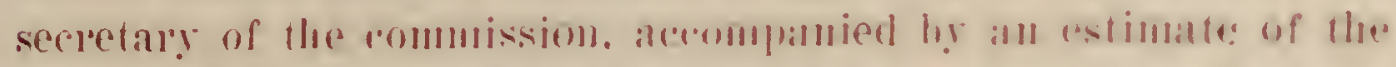

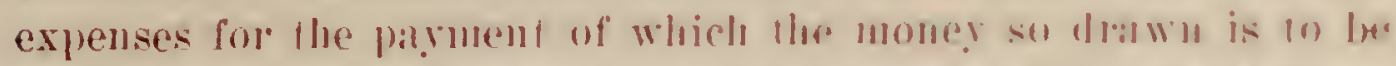

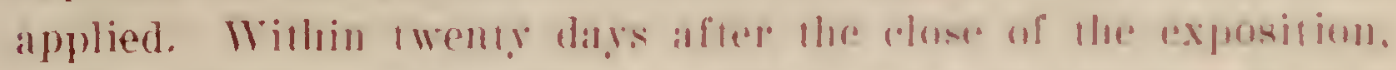

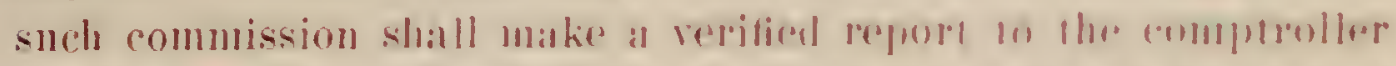

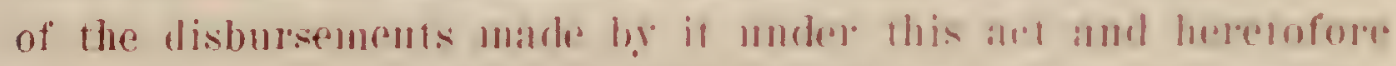

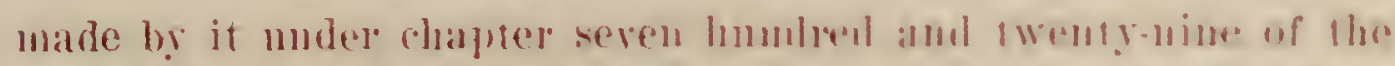

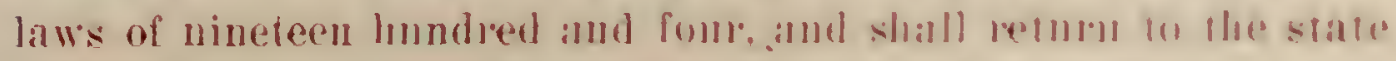

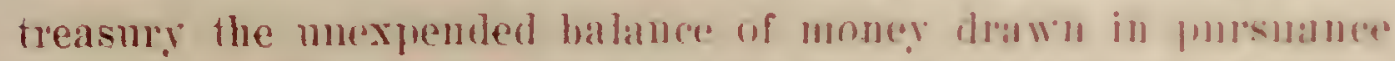

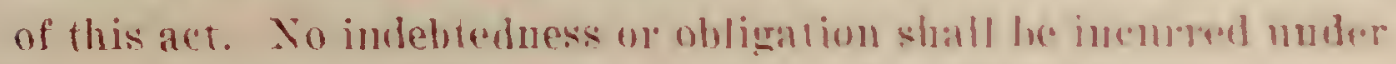
this act in excess of the leapumpurialion heroin mathe.

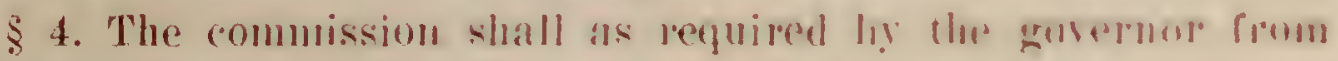
time to time rendel to him reports of its furomedings.

g. 5. This act shall take refret immedialely. State of NEw York,
Office of the Secretary of State.

I have compared the preceding with the original law on file in this colfice, und do hereby certify that the same is a correct transcript therefrum and of the whole of said original law.

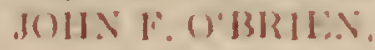




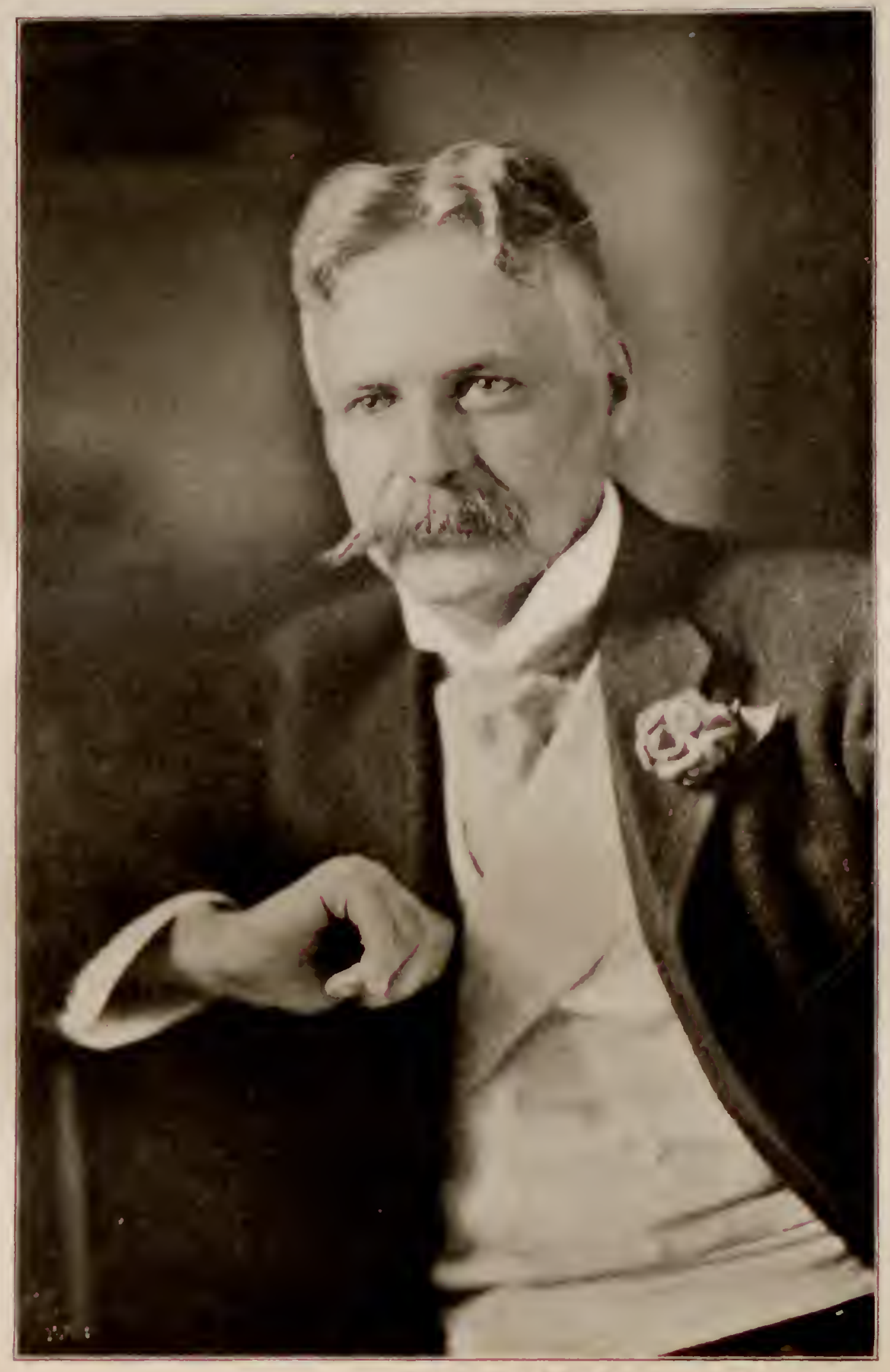

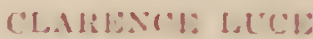

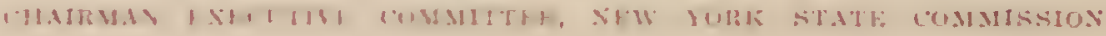




\section{COOPEA \& UNION, * NEW YORH}


With the beginning of February 1905, the work of the Commission conmenced in earnest. It had invariably been the custom of previous commissions to appoint as secretary a man from without their membership who served at a fixed compensation, was present at all meetings, kept the minutes, directed the detailed work-iu fact the executive oftecr. Commissioner Lnce, who had heen elected secretary pro tem, understanding through previous exposition experience the multitude of demands upon such an appropriation and that the salary of a man equipped to do this work would he a large item. offered to retain the oflice without compensation. He furthermore offered to prepare plans for the siate hulding and supervise its construction withont cost to the State. This action was applanded by his asso. ciates who welomed the opportunity thms to husband an inadefuate appuppotion. and they immediately passed a resolution accepting Mr. Iares nffer. and feudering him a rote of thanks.

It a moeting of the ('ommission held at the Hotel Ten Fyck, Albany. February 16th, Mr. Luce submitted plans for the state bulding, which is described elsewhere. These plans were leartily approved, and he was anthorized to obtain bids for the construction of the hulding with the proviso that at the conclusion of the Fail the structure shonla become the property of the confractor. This action salen the state considerable money inamuch as a roasonable deduction was made hy the contractor for the value of the builhing, and noreorer he was moved to use better material in construction than if le were to lave no further interest in it. Furthrunore, at the conchusion of any exposi. tion, so murel comstruction material is thrown mpon the market at one lime that it is afsolntely impossible to obtain anything like a fair return on il. 
In response to the invitation for bids. seven were submitted. the lowest of which was $\$ 10, \$ 12$, from the Eureka com. pany, at st. Louis, Mo. This hid was arepted. and Com. missioner Luce was authorized to propeed to Portland, close the contract on behalf of the Commission, attend the gromd-breaking ceremonies as the Commission's representative and make full arrangements for the completion of the building before the date of the opening of the lixposition.

The site of the buiding was upon land leased by the Exposi. fion company from a citizen of Portland, and before the building was completed, the contrator had sold it to the owner of the land, to be turned orer to him after the state of New York had surrendered it. On accomt of the future use to which the prospective owner desired to put it. a better foundation than that contracted for was provided, and many inpurorements not contemplated in the miginal contrat were marle. ly which the Commission profited at no additional expense. Them were less than three months between the ceremony of gromud-hrathing and the opening of the bxposition in which to conpletw the structure. but, as told elsewhere the building was entiraly mally for the reception of gnests upon the opening diy.

In Februaly, Delancey M. Ellis, of Rochester. Was alpwinted by the Commission as Director of lixhibits to take offect Warch 1,1905 , to complete the work falling under this head and such other duties as the commission might impose upon him for the sum of $\$ 3,100$. Early in Jnne his title was changed to that of Executive officer.

The Treasurer was authorized to enuloy such relical assist. ance as might be needed in his onice at a smu nof (1) (xirnst \$250, and under this anthority appointorl Mr. Hethert I. Hick. man, of Butialo. as rerk to the Traisumet. 
The supply hill of 1905 , which becane chapter 700 of the laws of that rear, contained the following item:

"For the New York state Commissioners of the Lewis and rlark (ontennial Exposition, in defrying the genemal expenses of sald commission, and for lansportation of exhibits to Portland. Oregon, and retmrn, and for such other expenses as may he repured in the work of satid rommission, including actual, meressary and traveling and other dontingent expenses incured by the sald commission. twenty thonsand dollars

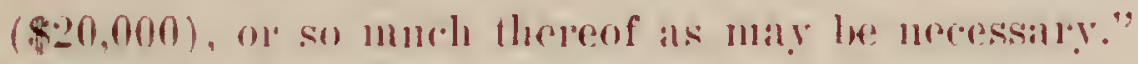

With rlis additional apploplotation assured. the rommission

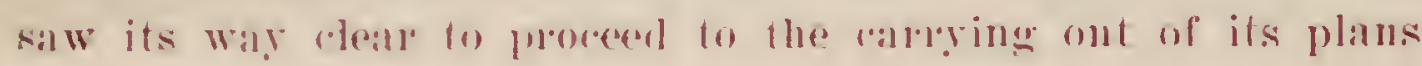
sol the states participation.

The puestion of a restambant for the alcrommodation of the visitors from the state and otheres was hromght to the Commis. sions attention hy a proposal from brumo l'indat, of New York. who offered to pay the state the sum of $\$ 5,500$ in tratde for the privilege of conducting a restanant in the state bnilding, snbject to the silme restrictions which had been imposed by the Louisana Purelatse Exposition Commission. Mr. Pindat's proposal was afceplfed. In offor Wals also received from Messis. steinway and son to plare in the state building a Steinway yrand piano of special design. likewise an ofler from Mr. Leon Werson. of New Vork, to rontribnte some artistic panels of deconated leatler. for the mubellishment of the building. Both af these offers were atecepted ly resolution, and the thanks of the commission were tendered in both instances.

At the mepting of the commission held early in Jily. Ifr. Green retired from the preidency and the Commission, the then Vice-President. IM. Warl. sureeding him als President. 
The members of the Commisimon's staft were appointed from the dates set opposite their manes, and served the sitate failh.

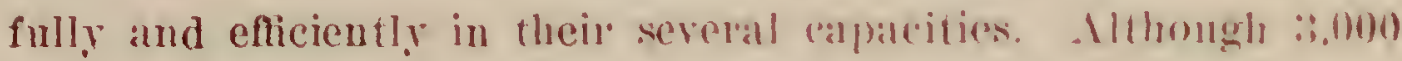
miles from home, practically the entire stath was malle up of appointees from the Empire State. "the nanks of the mimbers of the stafl and date of appointments are appended:

DeLancer M. Ellis, executive oflicer. \$3.100. Manteh 1. 1914. Seward П. French, assistant. \$125 per" mo.. .lune 1. 191\%. Hugh .T. Kélly. assistant, \$100 per mo.. Mareh 1. 1910..

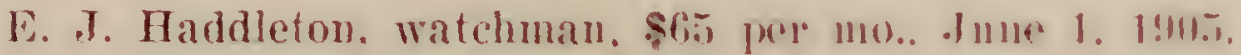
C. R. Hotchkiss, attendant, \$fin jer mo.. Inn 1. 1:40.s. T. F. Carney, attendant, $\$ 60 \mathrm{per}$ mo., Jume 12, $191 \%$.

Albert Helmkamp, attendant, ş60 per mo., Tnme 1. 19m5.

Frank W. Stewart, attendant, ston per mo.. Inne 1. 1!n.s.

Robert Mayes, page. \$nj per week, June ti, 1905.

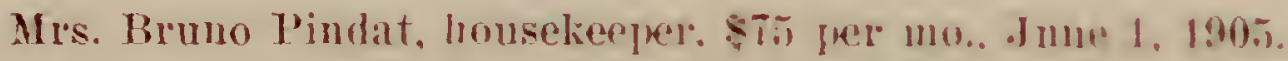

Lizzie Vogel, maid, șin pel mo., Inne 1. 190\%.

Mary Harms, maid. sin per mo.. dme 1. 1905.

Helen Noonan. maid, \$5a per mo.. Junte 1, 190\%.

The wisdom of the Commission in deciding to erent a state pavilion was demonstrated not only in the raphloitation grimen the State by the appearance of such an atractive strmefmp and by its use on the part of the Exposition Company for its ofluonl entertaining: but surprisingly by the munter of hon: fido New Yorkers who placed their names upon the registor dnring the life of the Exposition. When it is taken into considmation, first, that many New Yorkers did not register at all, sormml, that many more used the building during a considerable length of time, registering but once, lhe total as given lwhol is truly remarkable. 
The registration was as follows:

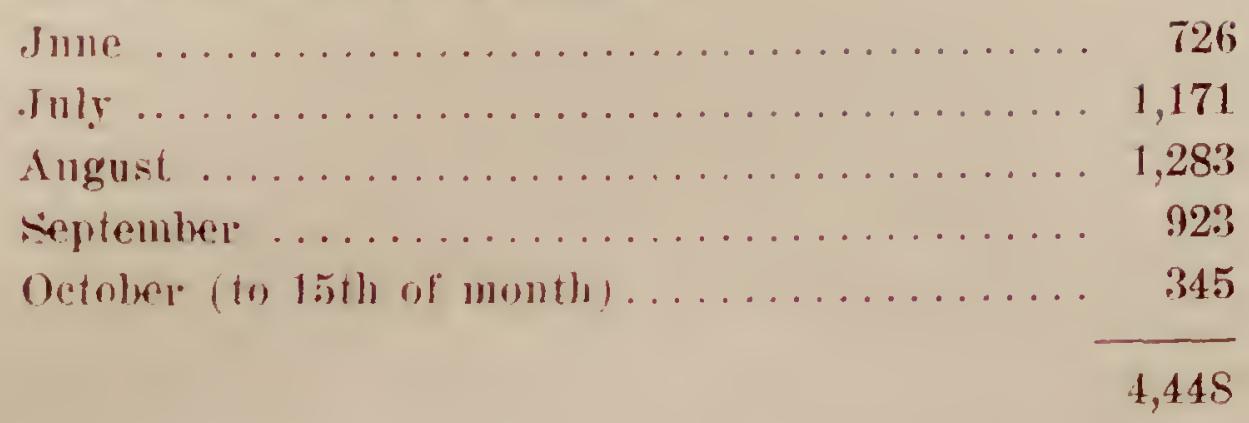

Brief bingraphinal sketroses of the members of the commission follow:

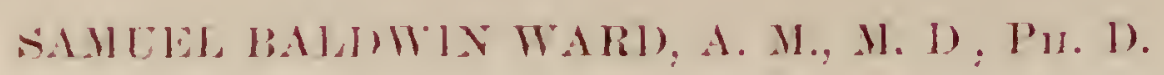

Dean of the farmlty and frofessor of theory and practice

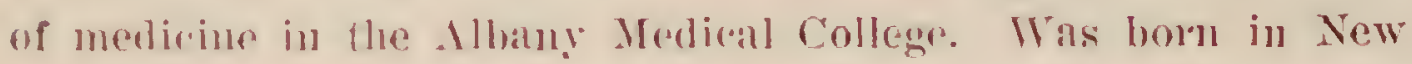
York ('ity. June s, 184:. He was edneated in mivate schools in the Cit! of Yew York. first at Dod's and later at Masset's and Villeplaits. He entered Colnmbia in 1557, and graduated in 1861 with the degree of bachelor or arts. Following his gratuation, lie atfended lectures at the College of Physicians and Surgeous, registering as a student in the oftice of Dr. Willard larker. Larly in 1862. he entered the service of the Sanitary Commission, and later in the same year became arting medical caldet in the United states Aluy. The following rear he was promoted to areting assistant surgeon, and in 1864 was commissioned assistant surgeon in the United States Volnuteers, having previously ohtaned the degree of M. D. at the Medical Department of Gengetown University.

At the cluse of the war, he spent a rear of study in the European lospitals and then returned to New York City. where he entered on the artive practice of his profession. While in New York he was connected with the college of Physicians and surgeons. Was forfessol of anatomy and smerey in the Woman's 


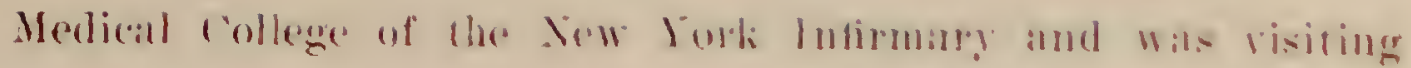

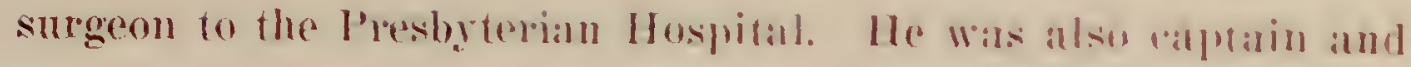

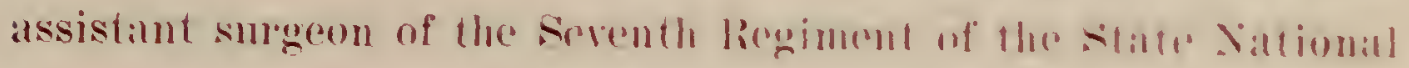

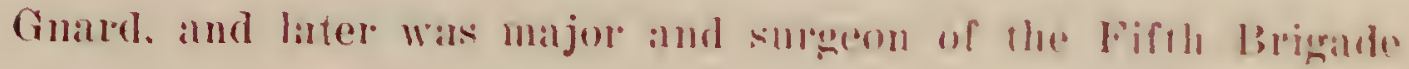
of the Guard lrom 1Sr!l to ISSI.

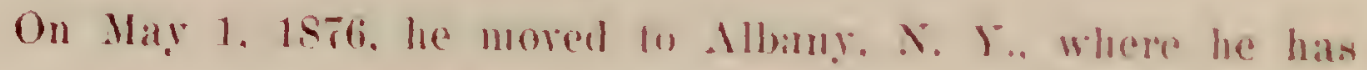

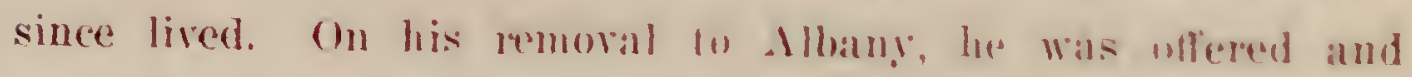

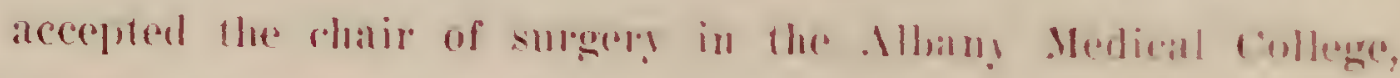

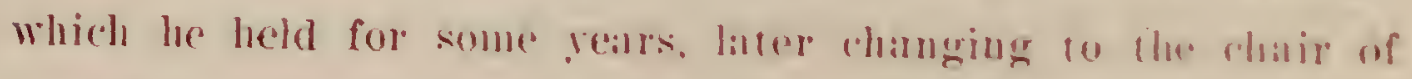

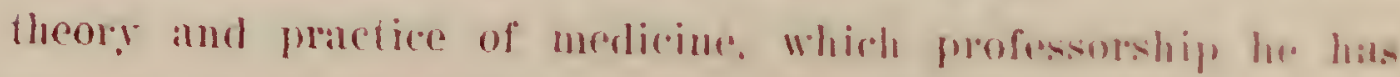

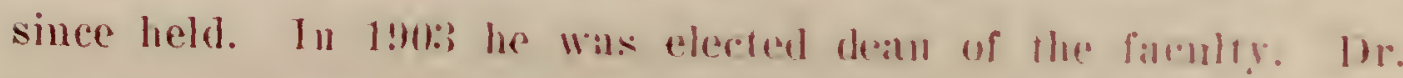
Ward was formerly comsulting phisician to sit. leperos Hos. pital and president of the lioard of cummissiomers of siate

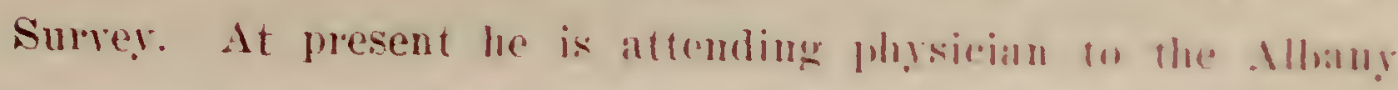

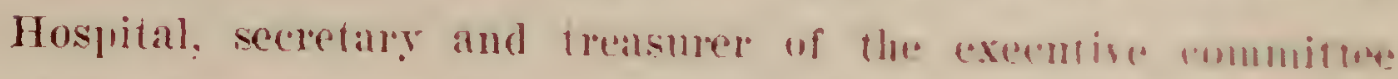

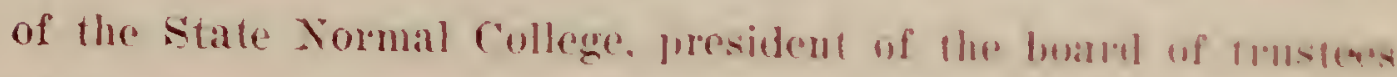

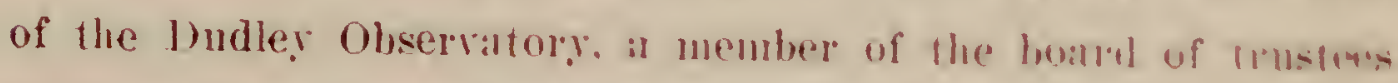

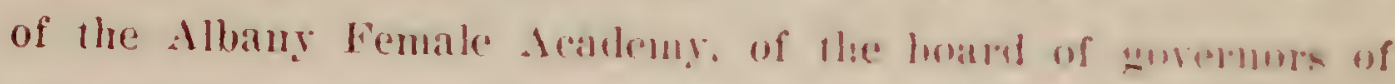

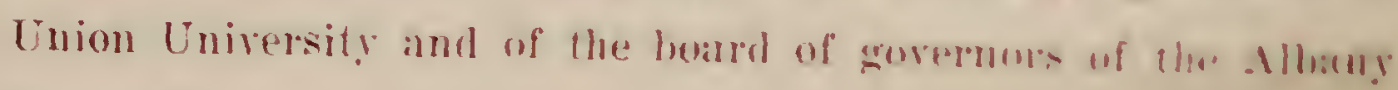
Hospital.

He has also been a member of the Cify board of Health and

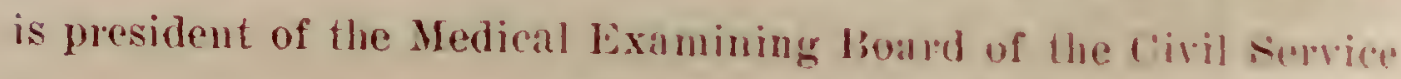
Commission of the State of Xro York. He is also a memblem. and ex-president of the Albany Comnty . Iedical siocion!. a mem ber and an ex-president of the State Medieal Sociel!: a mbulw. of the Association of American I'lussicians, of the compry Asson ciation, the University Club of Xew lork City. the loret orango

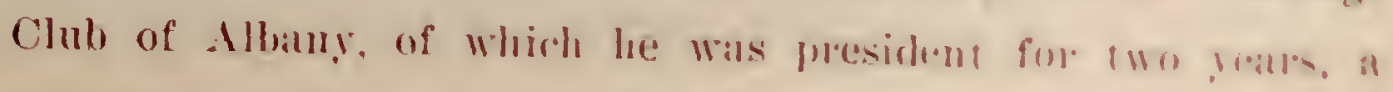

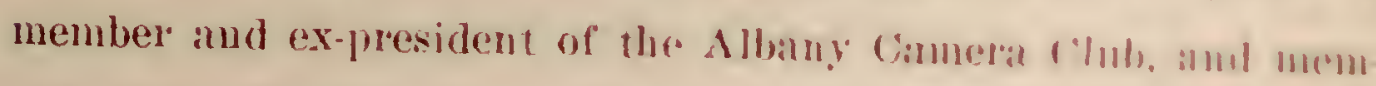

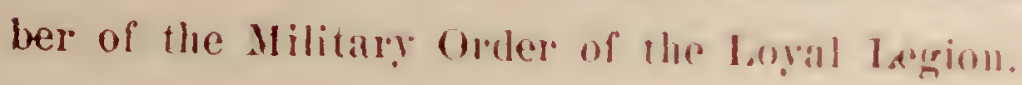


On October 10, 1871, Mr. Waml marrend Miss Nina 1. Wheeler

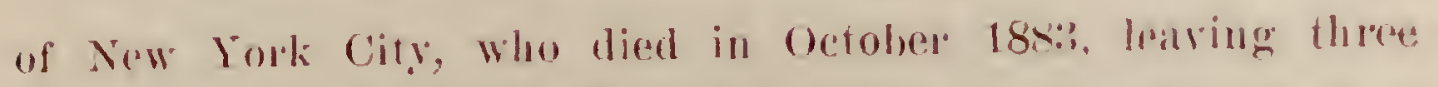
children: Nina I'., Annie W'. and S. Dwight Ward, all of whom are now living. On April an, 1897, lo marred Frace Fit\%. Randolph. daughter of the late lise. Ir. Noals sulenck, of Brookly!l.

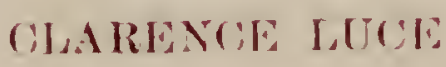

Was horn in Chicoper, Massachusetts. June 10, 15.jt. His parents moved shorlly hereaftel to Haylenville, Massachusetts. He spent four years in the scientific school, Williston seminary, Easthampton, Massachnsets. In 1870 he Nent to Boston, aud

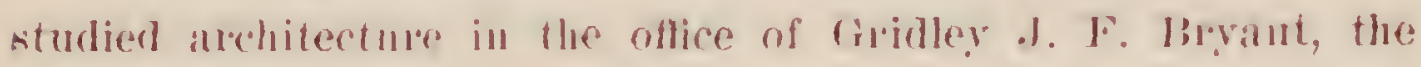

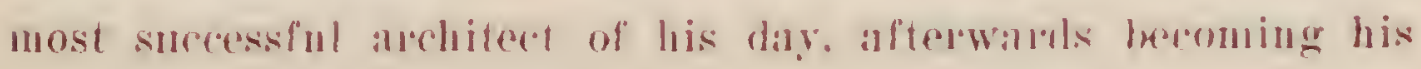
partuer.

He took a conrse in the lowell Instime and atrended lectures

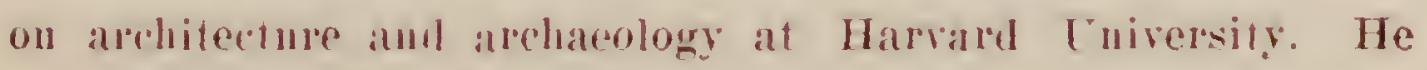
moved to New lolk in 1sst, and met with signal suceess in his hosen profession.

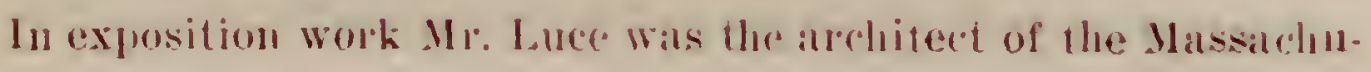
setts sitate huilding at the Philadelphia lixposition in 1876 , archi.

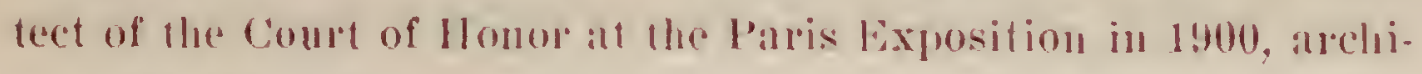
teet of the New lork state building at He sit. Jouis Exposition in 1904, and leveived goll medals for all of them. The exrellence of his work at St. Lomis prompled Governor Orell to appoint him on the New Yolk Commission to Portland.

\section{H.RRIT). WILIIAMS}

Was horn in the village of Uamilton, Madison county. Vew York, October as. 1862. He mored to hintialo in $186 t$ and has 
resided there since that time. He was educated in the public schools of Buffilo, and bater ly private instmetion. He was admitted to the practice of law in this state in Jannay 1854.

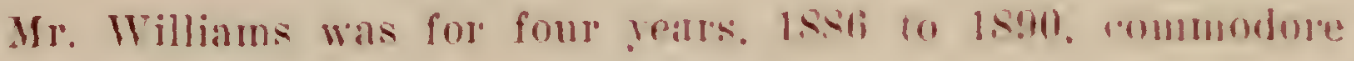
of the Buffalo Yacht Club. and for fiffere pears one of its board of directors. He is a menter of the sinturn Chmb, the Butlalo

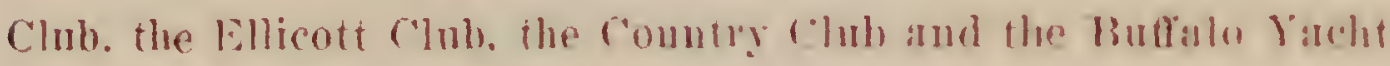
Club.

Mr. Williams. from 1ss to 1 sth was rery actire in local

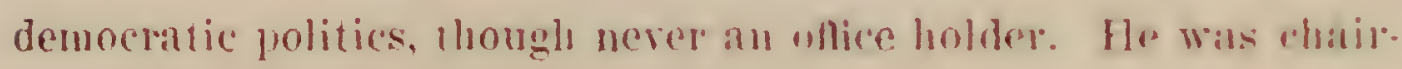
man of the Buflate Democratic ('ily Commitfere and member of the Erie County Democratic Commitlee. In 1 Sng he was chair.

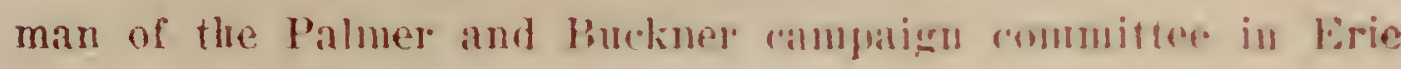
connty; and with his assoriates conducted an artive campaign among the gold democrats. In 1 s. Ms Mr. Williams hecame a republican. April 2\&. 18!1. Mr. Willians married Lonike, daughter of Lawreme Skey, lisin. of l'ort Mover, Outario, Cauada, and has two dhidren. Lawrence lientege, nged 14, and fonrge Bennett. aged 4.

\section{PRATT A. BROWY}

Born september 4. 187t, in Dublin. Law and is the son of William W. Brow (now deceasod) formerly a member of the Republican National Committer. Resided from 1875 until the fall of 1892 in Macon, Georgia. Ornduated ut Mercer University, Macon, in 18:2, and at the Acadenic llepart. ment of Yale in 1894. Attended New York Law Srhool and was graduated in 1896. Admitted to the bas at the Jum lorm of the Appellate Division of the Supreme Court in 189\%. Becane associated with the law firm of Evarts. Choate os Breman in April 


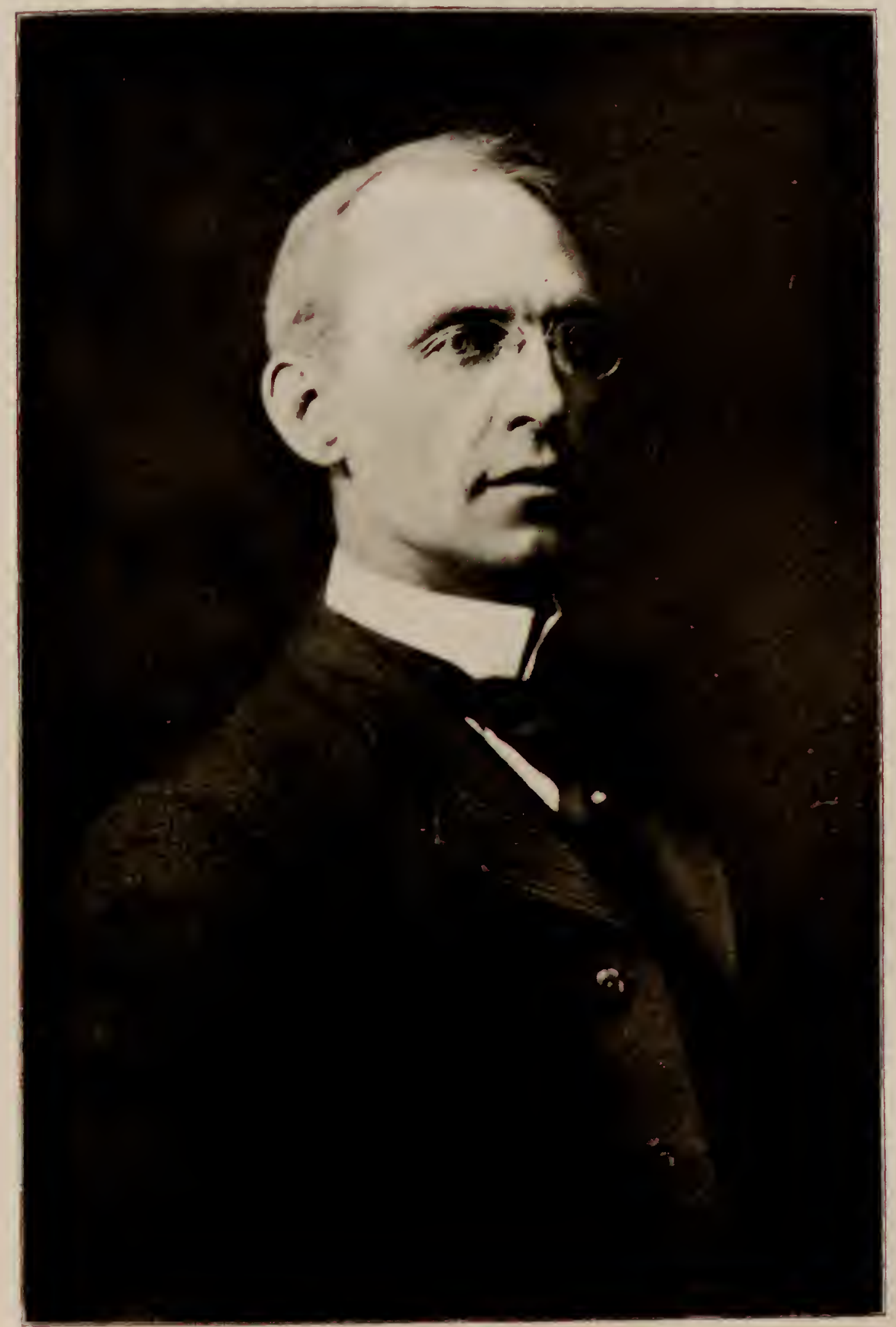

HARKS D. WILLAAMS

A H.LASLEE, VEW YUKK SIIIE CUMMSIUV 
(n) 
1895. and continted association with that firm until its dissolution in 1902. 'Then became associated with the firm of Nicoll, Anable \& Tindsay of :31 Nassan street, New York City, and was placed in charged of lle litigation growing ont of the construc. tion of the Rapid Thansit snbway, in which pnosuit he is now engaged. $11 \%$. Brown has taken an active interest in politics, heginning with the presidential clection in 1896 , when he took the stmmp for Mckimley. Has served as secretary, nember of the Menbership Committer, (halman of the Committee on City

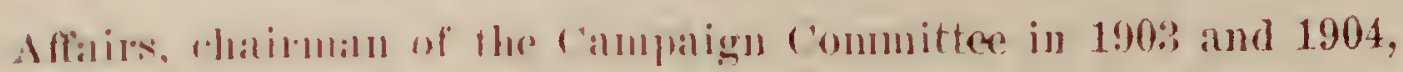
and thipl vicp-presideut of the Republican Chub of the City of New York. Ho is nne of lle directors of the Society for the Prevention of rime.

\section{HINRI AITHAN}

Born in the town of lndiana, Penusylwaia. Served an apprenficeship to the tanning husiness with dames Toronce, in Punxsutawney, Hat state.

Went to Minresota in 1852 by steamboat via the Ohio and Mississipli rivers, He only ronte thither at that time. That rear fook ny a dinim adjoining the original fown site of Lesueur on the Minnesola river. Indians broming threatening, abandoned it. That and following year engaged in rafting logs and lumber on the Mississippi rire between St. Panl and St. Tonis. From 185:3 to 1, shif engaged in the hunber and ice business in Muscatiue and Mavenport. Jowa. In 185s-5? nember of the Hemoratir state Committee of Towa and in 1860 as its chairman conducted the Donglas presidential campaign.

In 1861 went to Colol:irlo. starting from the Mississippi river

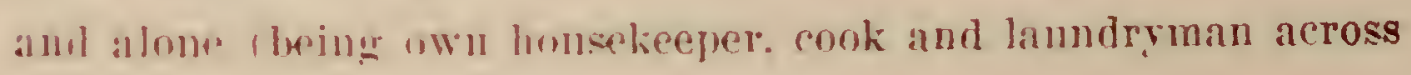


Iowa and the plains). With wagon. thee foke of oxem, one row, two pigs, 3,000 pounds of potatoxs and two pommls of siroll county, Iowa, onion sepls.

Arriving at Denrer; cut the eyes mut of the potatoes. planted them. sold the remaining portion for sixtern rents per pound. and the omion seeds for sixteen dollars frel wner. Was ongaged in mining in Color:alo for several reats following. Anring which

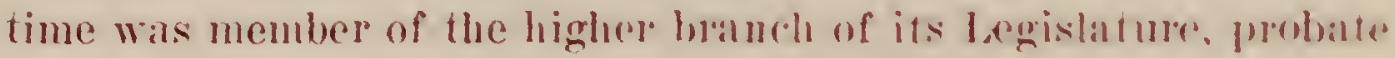
judge of one of its comnties, and chatman of thr bemoreallic Territorial Committee. Procmed from its first Idristature of 1861 the fust Pacific Railouad charter granted hy any legrislative

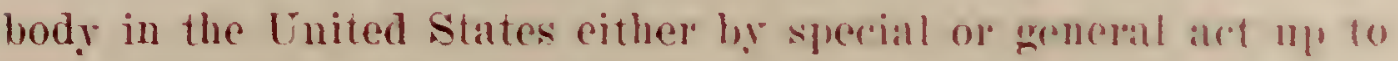
that time, its franchise title beingr lhe "lolorato and Parifie Wagon. Telegraph and Railload r'ompan!."

Came to New York a second time in Lstit. Silne Yratr married Mrs. Philip Hone Anthon of that dity. who died in 1ssit. In 1871 went to London, remaining abload six rears promoling land. mining and railroad enterprises of the l'nited silates and wher comntries. Returning. engaged in enterploisos in and abont dew York, mining in Colorado and total, and at present in Montana. being the president of the .. Sacajaweal ciold and foplfu'l Co." of that state. Yoted for General frant for Prexident in 1sfs, and with the exception of sevelal partial lapses, has lyopll a steady high prirate in the G. O. I'. ranks erel since.

\section{CHARIES R. HINTISI}

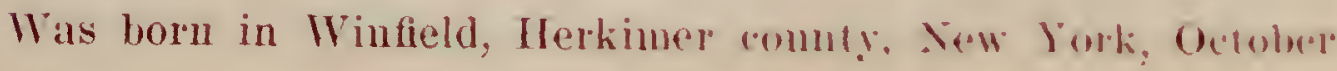
12, 185t. Iate in the 70 s he settled an lintlalo. New lork, and in 1878 became general agent of the standalol ()il company and

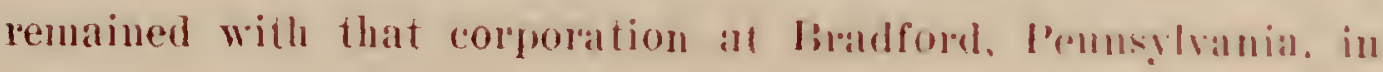




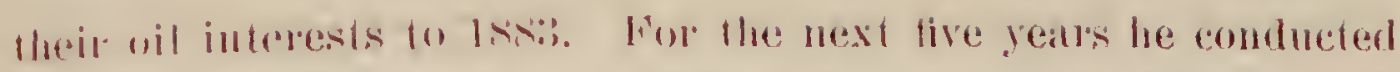

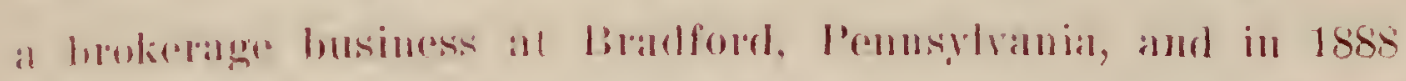

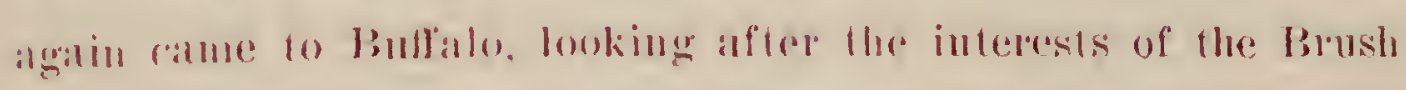

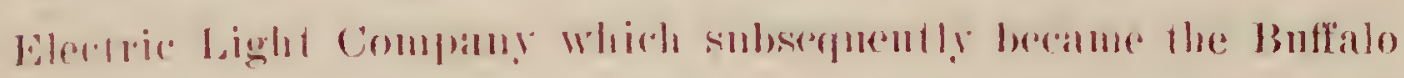

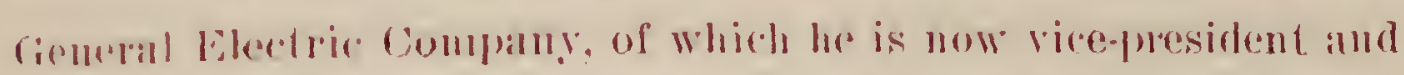

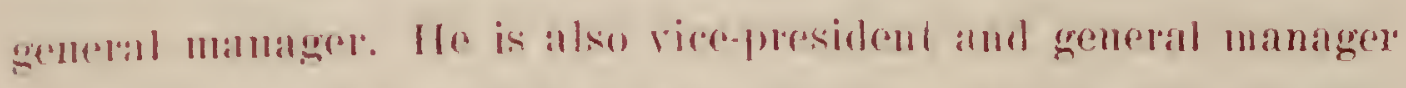

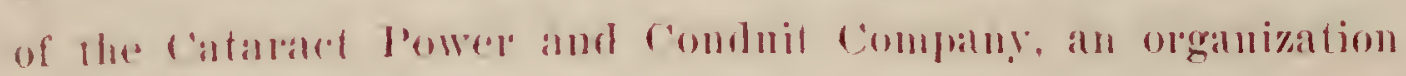
Whidh has the distrihution of Niagara Falls fower; vice-president

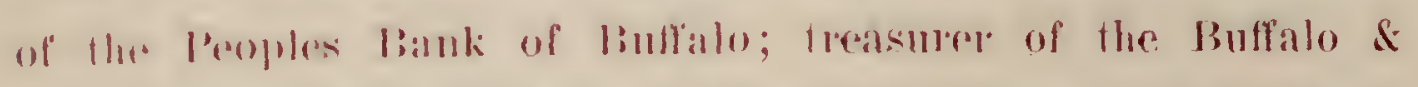

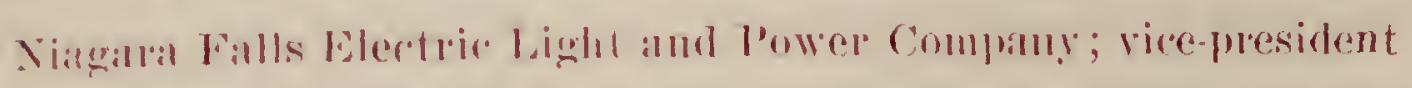
of He Wrestern New York Waler Company; president of the

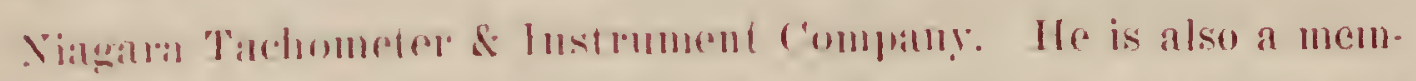

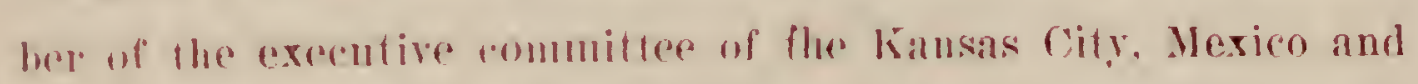
Grient li. K., and a furmer president of the National Electric

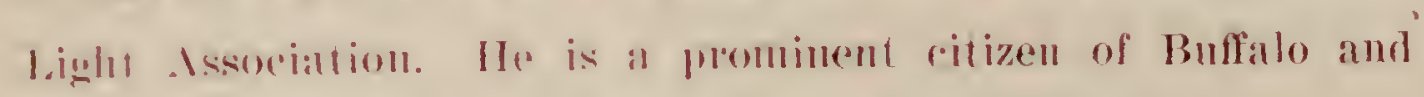
has borol idoutiferl with all mogressive movements. 


\section{CHAP'TER III}

New York State Building 



\section{NEW YORK STATE BUILDING}

I' 1 ' not only the anty but also the pleasure of the New York Commission to make dne acknowledgment in this report to the officials of the lixposition for the genelosity, even partiality, shown the Empire State in the allotment of a site for its State building. It was a subject of general remark that no State building was more alvantageonsly located than that of the Empine state, with the possible exception of the Washington State building, which rommanded parctically the same view from the west that the vew Yolk huilding did from the east. Unlike other expositions whicle have gone before. the pavilions of the varioms states were not confined to one particular section of the olpomds. but were located in various suitable places so as lest to contribute to the grneral eflect. The New York building was one of the pleasing features of the "main picture."

The min picture, so-called, of the lixposition as viewed from Guilds lake consisted of gently sloping terraces rising from the level of the lake about 150 feet to the plaza upou which the main gromp of bullings was located. These terraces were cut by the gramd stairease learling from the sunken gardens to the lake, and also by mumerous walks and drives, while dotted here and there were immense flower beds filled for the most part with Polland's (hoicest blossoms-roses. This pieture was framed on the west by the wookled park, on the south by the Agricultmal and loorign Exhibits buildings. and on the east by the New lork state building.

'The building was located ahout midway up the hill. thus afford- 
ing to the north a most sweeping riew of cintld's lake. Gorernment peninsula, the Willanette river and ralley in lho distance. and to the west the well kept lawns and flower heds of Centennial park and the vari-colored and fantatstic shaperl stmotmos upon the "Trail." all of which stood ont boldly lrefore the wooded background formed by Willamette Heights. 'T' the east and

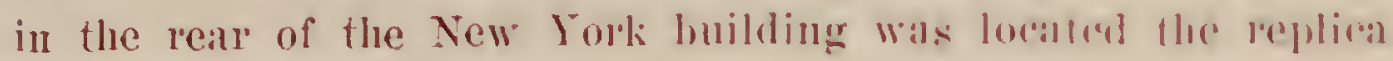
of Lincoln's home which was nsed as a State hulding for Illinois, adjoining which was a rest pavilion also created ly the lllinois Commission. Yortl of the Illinois building stood the Ldahn huilh. ing, while ar little further to the nortlo stoon the huilding ereseted by Utah. Last of the Lllinois building was localed at reprodurtion of the Lounfellow home erected ly the statn of Mallur. and used as its State building. Just to the sonth of the Hllimis lmilding the Exposition Company erected a large favilion will an anning cover which was nsed for large receptions, dances, cole., and a corered phassageway was built by which it combl be connected with the New York State building as occasion requirent. It soon became known as the Pavilion Amnex, and was the serene of many brilliant functions during the kxposition meroul.

The Oregon building was located near the main enlmuce, and while it was more acressible fo visitors npon controbe flo gromurls it was so located as to command none of the leamliful ristas which were visible upon all sides from the building of the Funpire state.

The site was formally turned over to the Commission on . March

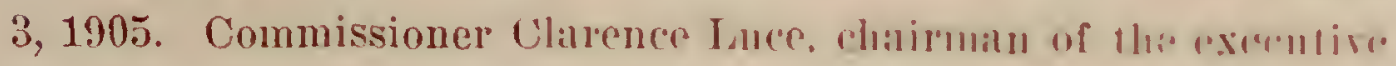
committee, who was also the architect of the lnilding. Writ in Portland for the purpose of representing the New lurk Com. mission upon that occasion and of formally acerpting llee foudere. On the day of the transfel of the site. Commiscionel Lowe was 


$$
8
$$




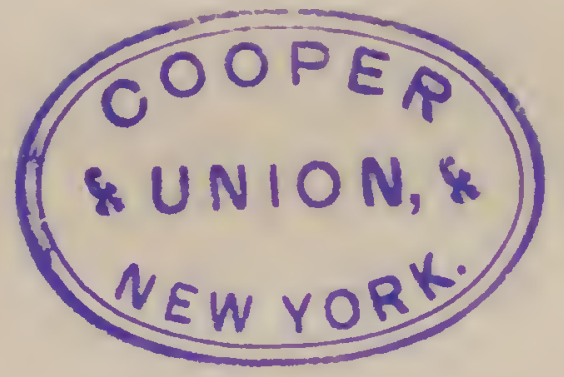


given a luncheon by the President of the Exposition at which were present inany of the bxposition's directors and prominent citizens of Portland. At the conchnsion of the luncheon the guests. accompanied by the wives of those mentioned above, proceeded in tallyhos to the bxposition grounds. going directly to the site. President Goode briefly expressed the gratification of the Exposition Company and the people of the State of Oregon that the Empire State was to participate in the Exposition, and stated that he fully realized that hel participation would be of great benefit to the Exposition and to the Northwest, and hoped that in some measule benefit wonld accrue to the State of New York on account of surh participation. He then in the name of the Exposition management made formal presentation of the site.

In his respouse accepting the site, Commissioner Iuce thanked President Goode for the conrtesies shown him upon that occasion, and stated that a lively interest was being taken throughont the Wast in the Exposition. He added that he hoped that the plans for the participation of the Empire state would meet with the approval of the Exposition autlorities, and expressed his own thanks and those of his colleagues upon the Commission for the consideration shown the state in the allotment of a site.

The first sparleful of earth was thereupon lifted by Mrs. Goode, wife of Iresident Goorle, after which spadefuls of earth were lifted in tmo by l'resident roode and Commissioner Tuce. This completed the brief but impressive reremonies.

The building of the state of New Sork was one of but very few entirely ready for the reception of guests on the opening day of the Exposition. It is recorded elsewhere how the pro. reedings of that day were clustered in and about the building of the Empire state. While not as large as the buildings of 
some of the other commonweallis represented. there was a simple dignity and quiet elegance about the strneture which semed to at once impress the visitor with the fact that it was New York's home even before he approached near enongh to reid the letters proclaiming that fact over the entranceways.

The Commission was confronted with the publem of erecting a suitable building upon an appropriation which semed to render results commensurate with the dignity and prestige of the State almost an impossibility, but a solution was reathen by the gen. erous action of Commissioner huce in oflering 10 prepare the plans and superintend the construction of the bnilding withont cost to the state. His artistic taste and ripe judgment supplemented by his experience gained in previons expositions as to the essentials in the construction of a building of llis kind brought forth results which seemed almost incredible considering the amount expended. for which the commission wis compli. mented again and again.

The building was planned primarily for the comfort, conve nience and accommodation of visitors from the Empirm state for the holding of such functions as were given under State auspices, and to be a place where the sons and daughters of Now York who had before left the old home to seek their fortunes in the great West could meet each other and those old friends who were making a brief trip into that part of the country. Further. more, it was to stand as an evidence of the corlial feeling of the Empire State towards its sister state and appreciation of the fact that the prosperity of the two commonwealths were in a great measure interdependent.

The building proper, which was two stories high, covered ap. proximately without rerandas 3,200 square feet $(40 x+0)$, and a 
one story addition at the rear which was known as the exhibit hall contained 1,250 square feet $(25 \times 50)$. The structure was pure Italian in design, and on the nortl and south ends were verandas from which liuge columns arose supporting the roof line above the second floor and giving an old colonial effect.

It can fainly be said that there were three main approaches from the very nature of the location. On the north the building was reached fron Grey's boulevard by a grand stairway flanked with parapets containing lunge vases of hlossoming plants, and which diverged half way up into two smaller stairways, one on either side, by each of which the north veranda was reached. On the west was an entrance for perlestrians leading directly in the building proper. On the soutl a short flight of steps led to a circular relanda from which one enteled the reception rooms. This was the entrance most commonly used, being nearest to an arenne much feynented by Exposition risitons and also most convenient for those arriving in carriages.

The north veranda extended some distance beyond the line of the columns, and was used in conjunction with the dining room as a private iestamint for the accommodation of New Yorkers and their friends. The structure was so plamed that from most iny entrance a very cliaming vista greeted the eye. In the centre was an octagonal rotunda running the full lieight of the building and cappred by a circular dome so planmed that the hallway on the second flool shirted the elge of the well. This liallway was supported hy eiglit pairs of circular colmmns. In the four diagonal sides of the rotunda were pliste mirrors encased in French sash. The effect was chamuing, and aplurently magnified considerably the size of the rotunda.

The stairway ascending on the seromd story followed the line

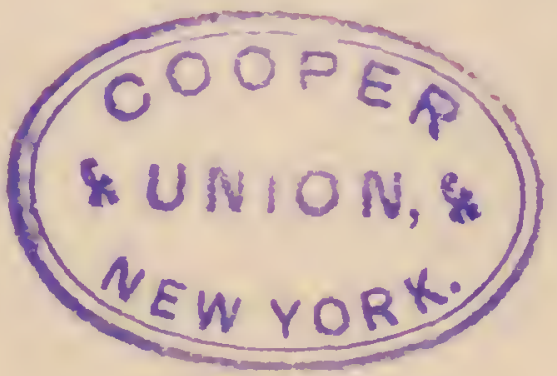


of one side of the well and was ingenionsly roncenled behind it.

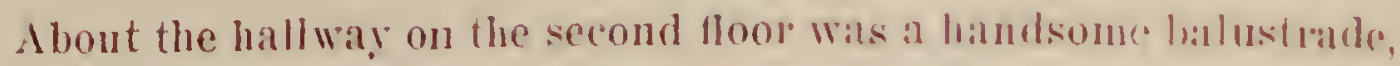
in the panels of which were placed entablatures containing the coat of arms of the siate of Nen lork about cighteren inches high. To the south of the rotunda was the recention renum about $25 \times 10$ feet broken in the centre by two paris of colmuns. The interior finish was of paneled wood painted a pure white. the

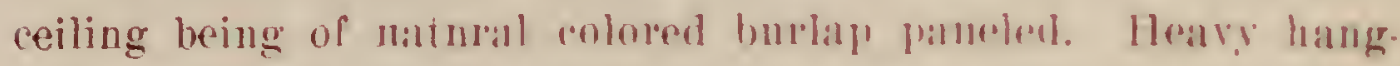
ings of green tapestry draped the livenell windros which opened to the floor. the mission furniture usal "x(elusively being uphol. stered in Spanish leather and painted :1 fun while.

On entering the loom, ome's implession wats llat of loutfuluesn

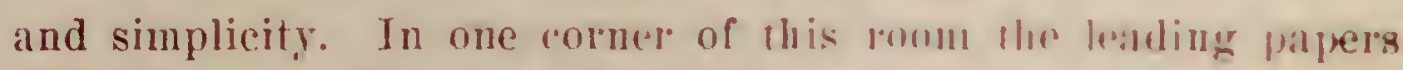
and periodicals of the state were on file. That llis feature was fully appreciated was temonstrated hy the mumber of penple that made use of it. Man! of the Sew lorkers who visited the Fair made their sojomrn in l'ortland an incidenl of a sumewhat cxtended trip through the western conntr? and an "1pmolnumity on see newspapels from home llas apprecialled. Tho cimminsion acknowledge the contes! of the publishers of the following pub. lications in sending them to the Sew Vorls state luihling during the entire Exposition period:
Adams (Jefterson County) Albion (l) reans Connty) Re Journal publican
Albany Argus
Albany Jourual
Albany Press and Knicker. bocker"
Amsterelan livening Recorder Irmy and Navy .Iomrnal
Albany Times-Union
Anbmrn Linlletin
Imburn Girizen
Ratavia Maily Sews 
Bath (Stenben County) Advocate

Binghanton Evening Herald

Binghamton P'ress and Leader

Binghamton Republican

Brooklỵ Citizen

Brooklyn Daily Lingle

Brooklyn Daily Times

Brooklyn life

Brooklyn Standard-Union

Bullalo Commercial

Buffalo Evening Nows

Buffalo Express

Cambridge (Waslington Comm. 1.) Post

Canandaigua (Ontario County) Jourual

Catskill Recorder

Collier's Weekly

Corming Evening Lealder

Dansville Advertiser

Delhi (belaware (omuty) bxpress

1)unkirk Fening Observer

Eilicottrille Post

Eimira Adrertiser

Limira Gazette

Fort Plain standard

Genera Daily 'limes

Glens Falls Morning Post

Glens Falls Times
Gloversville-Johnstown Morning Herald

Gouverneur Free P'ress

llion Citizen

Ithaca Daily Fair

Ithaca Daily Jomrnal

Janestown Evening oommal

damestown Post

Jndge

Keeseville (Essex (jounty) Republican

Kingston Daily Freeman

LeRoy Gayete

Teslie's Wreekly

Life

Lyons Republican

Massema Observer Press

Mexico Independent

Middletown Daily Times

Montour Falls Free Press

Mount Vernon Daily Irgus

Mnsic Trade Review

Newark Union

Newhurgh Daily News

New York City Daily Star

New York City Globe

New York Daily Financial News

New York Evening Mail

New York Evening Post

Yew York Evening Sun 
New York Jewish Daily News Rome Daily Sentinel

New York I'ress

Saratogal Daily Sallatogian

New York Stants-Zeitmmy

Schenectady kisning stan

New York Sm

Schenectatly Ferening l'nion

New York Tribume

Seheneratly Gazette

New York World

Oneida l'osi

sientific Anerientl

Oneonla Star

Syrancuse Post stamdard

Outlook

Orego Times

Town Topics

Troy brening siandurd

Penn Lan (Yates Comnly)

Chronicle

Plattsburg Sentinel

Potsdam Courier Freeman

Poughkeepsie Evening Sta

Pnck

Rochester Democrat-Chronirle

Rochester Evening Times

Troy Recom

Troy Times

liticat llaily lowes

Citimat Obsetrere

11:all street Intllual

Wilersown Haily Timm

Watkins lixpless

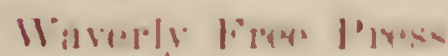

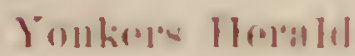

Rochester Post Express

The dining room was north of the leofumdat and innected with if hy an arched passigeway. The same froatument was now for walls and ceiling as in the reception lomons. It was the original intention that the restanmint features of the building should be coufined largely in the north beranda, hith ihrough. out the entire summer the erenings were invariahly so rool as to make it impracticuble to nse thr veranda to any extront afrer sundown. The dining room was the sceme of many hrilliant functions recorded elsewhere, and ofren its walls lasve echoed with the applanke provoked by the patrintice soltiments, anecdotes and epigrams uttered by man, distinguished mon. 
On the nolth wall hung lwo landsome panels of decorated embossed leather depicting scenes incidental to the journey of Lewis and Chark into the Northwest territory guided by the Indian I'pincess Silcajancal. These panels were the work of Mi. Ieon J. Werson, and were furnished the Commission through the contesy of Commissioner Iuce. 'The walls of both the dining room and the reception room wele hung with pictures of many of the most chaming bits of scenery in the state including tho Adirondacks, the Catskills and the Thousind Islands. Iniectly east of the rofunda was the office, which was easy of access to the pmblic. Here the business of the Commission was tuansacted, and liere, also, were located the burean of information, public telephome and other conveniences. Directly to the real of the oftice was the exhibit hall, at each end of which was a circular recess giving a chancel effect. The room was lighted fol the most part by a huge skylight extending practically the entire length of the room. The walls and ceiling were of gleen burlap of a neutral tint forming an appropriate background for the exhibits displayed. From this room a door led to the nolth veranda.

The second floor of the building was given over entirely to streping arcommodations for the nembers of the Commission and their guests. There were two suites, consisting of parlor, brilnoom and bath. at the north end. In the south end were five bedroums and a bathroom. The walls of the entire floor were of Oregon fir so roustructed as to give a panel effect. This wood has a most beantiful grain, and when planed a satinlike surface. Absolutely no finish was applied and no amount of paint or dressing rould have prodnced a result more pleasing. The replings were of burlap. either green or red as the 
case might be, set ofl in pancis by hatrens of lin. The furniture used was of curly maple. while dainty muslin hangings draped the windows. A plain matting covered the flooss. The entire scheme of treatment was very inexpensive and the effect was extremely artistic. The pooms were appropliate for summer and for the occasion.

There were many bits of artistic work in sculpture about the building, the models heing furnished by Philip Marling. Jr. These were most noticeable on the front of the building. Above the cornice line was an entablature which ion. tained the word "New Volli" on eithel" xids of Which was : Cupid, one hand resting upon the name flate. the other holit. ing a horn through which he proclaimed the prestige of lhe. Empire State. Surmounting the entablature was the roal of arms of the State standing three feet high. The graceful female figures stood out in clear relief against thr hlue sliv, and over all waved "Old Glory." Gronped about and above the entrance. way were four tablets containing the coats of arms of lire United States, the Iewis and liark Fxposition. Hor rity of New York and City of Buffalo.

A most pleasing feature of the holding were three hugr vasus standing three feet high, gracefully modelled and containing in relief the coats of arms of the United States. Whe rity of New York and the Lewis and Clark Exposition. Thess were kept filled with a profusion of blossoms and were a most attrate. tive embellishment either for the banquet table or thr reereption rooms as the case might be.

The lighting of the building throughum was by electricity. On the lower floor electroliers of special design were hung. They were circular in form suspended by massive chains. Fom 


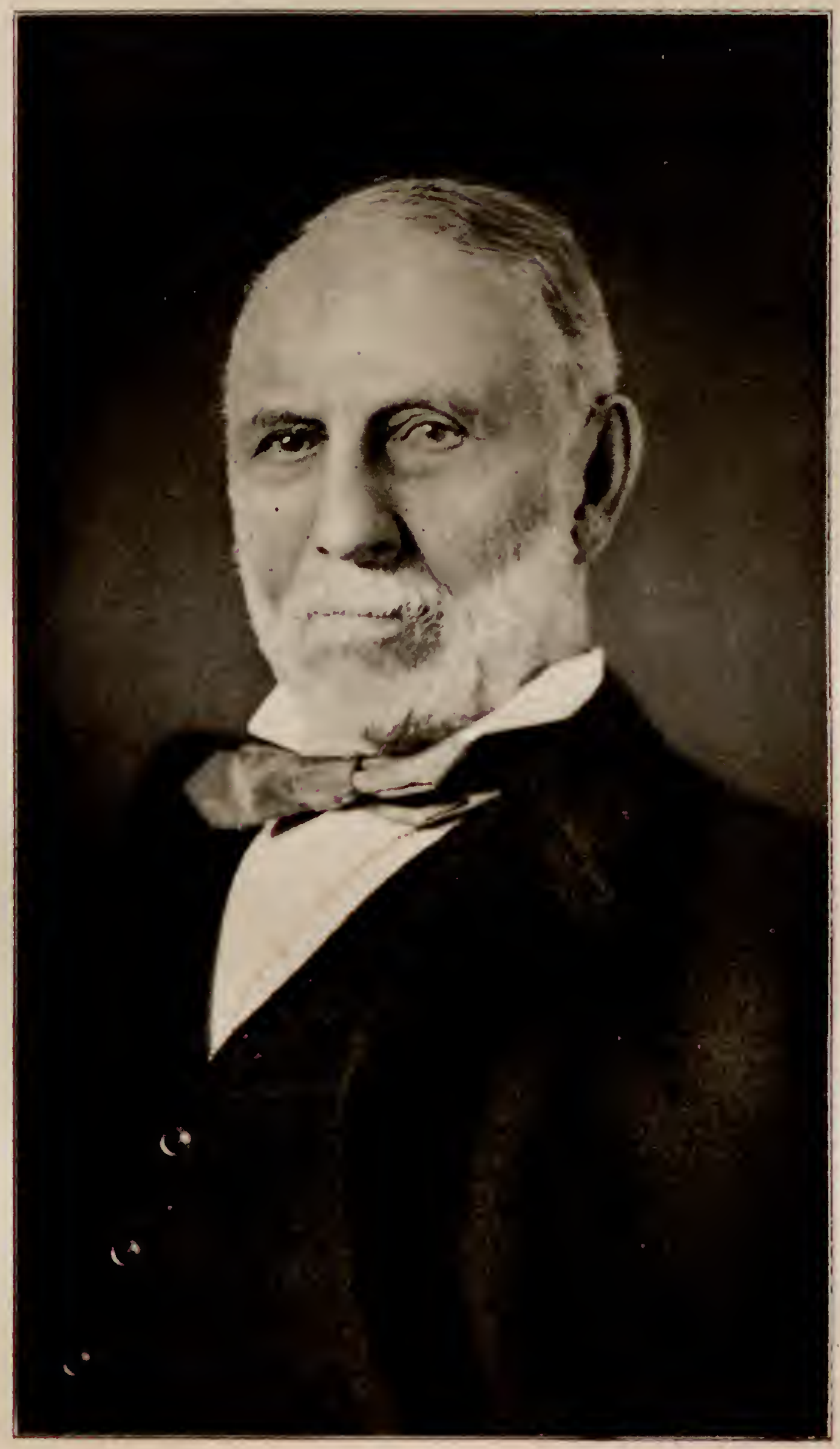

HENRY ALTWAN

NEW YORF: STATE COMMISSIONER 


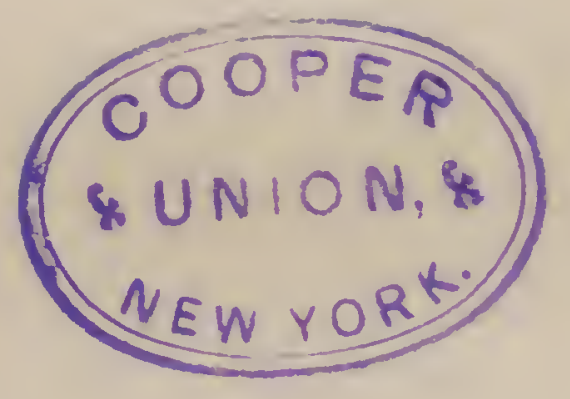


the rim of the circle hung smaller chains containing spherical globes. The electrolier in the main rotunda was particularly effective, hanging from the centre of the dome to a point at about the level of the second floor. This electrolicr, similar in design to the smaller ones, consisted of three concentric circles in graduated sizes and contained thirty-two lights. On the second floor the electroliers were extremely simple being of antique brass. The building was ontlined at night in electricity, 560 lights being used for that purpose. It was one of the features of the elaborate scheme of illumination which had been planned and was so successfully carried out by the Exposition management through the electrical engineer. Mr. Thompson.

One of the features which adder materially to the popularity of the building was a private restaurant conducted by Bruno Pindat of New York City. The kitchen and commissary department was in the basement, meals and refreshments being served either upon the north reranda or in the dining room. The privileges of the restaurant were by card only; and were extended to New Yorkers, Exposition ofticials, prominent citizens of Portland and Exposition visitors of note. The cuisine was most excellent and throughout the season appetizing meals ware served. Canopies were erected upon the north reranda as a shield from the sun, and the luncheon hour invariably found the talles all taken. In the evening these canopies were illuminated with electric lights contained in Japanese lanterns. This restanrant was the only strictly first-class restaurant upon the Exposition grounds, and it enjoged the greatest popularity anong those who were privileged to use it.

The Commission acknowledges the courtesy of steinway and 
Company, of New York, in placing in the state building a magnificent grand piano. This firm rnjogs the reputation of building only the finest instruments and that which was placed in the State buidding was one of the repre best which ever left the shop of this fanous firm of pimo lmidgers. It was the only Steinway piano upon the gronnds, and it was used several times for recitals and informal musicales griven ly noted artists and enthusiastic music lovers. The case was of mahog. any, the effect being antique colonial. Ahout the body of the case were inlaid panels depicting mythological figures represen. ing the human enotions-jos, love, sorrow, anger, hatred-as interpreted by music.

In expositions which have gone hefore the state may luve had more pretentions, more luxurious, more expensive and more enduring structures. hut the Commission believe that ir has never before erected a more artistic and at the same time more appropriate and useful structure than the one just described.

To Commissionel Luce the members of the Commission foel under especial obligations. He gave nnstintingly of his time and the resources of his oflice. to the sacrifice of commissions which meant large remuneration, and with his nsual enthusiasm he put his best thought into the work. For all of this the State of New York was charged nothing, lhus furnishing a refreshing example of public spirit in the midst of a mullitude of disclosures of hreach of trust on the part of many men charged with administering the finances and aftinis of ofluers. 
CHAP'TER IV

Exhibits 



\section{EXHIBITS}

SOON after the organization of the Commission in the fall of $\int 1904$, a communication was received from the Louisiana Purchase Exposition Commission offering to turn over to the Lewis and Clark Commission such of the State exhibits at St. Louis as the Tewis and Clark Commission desired, subject to the consent of individual exhibitors where their interests were affected. From the St. Louis exhibits in education, social economy, forest, fish and game, agriculture and science were chosen about foul car-loads of miscellaneous exhibit material which were deemed suitable for exhibition purposes at Portland. This material was stored for the winter at St. Louis, and early in the spring sent on to Portland. Sometime before, the hxposition company had determined that the exhibits of all states should be installed in the various state buildings rather than in the general exhibit palaces.

It was the original intention of the Commission to devote the entire lower floor of the New York State building to exhibit purposes, but upou arrival in Portland, it was learned that it would be impracticable to confine the restaurant, which in nearly all expositions has been a feature of the New York building, to the verandia, owing not only to the rainy season in spring and fall, but also to the fact that the evenings were invariably so cool, as to make it impossible to dine out of doors with any degree of comfort. Therefore it was necessary to give up the nopth room to restaurant purposes. Moreorer, provision was necessary for a lounging and resting room for New Yorkers and 
other visitors to the building, a reception room when functions were held, as well as for a reading room where the daily papere of the State could be placed upon fle. The south room was set aside to meet these demands. Consequently it was necessary to confine the exhibit to the exhibit hall and the Commission $\mathrm{s}$ office.

Under the circumstances it was impossible to install at one time all of the material taken to Porthand. Therefore the plan was adopted of changing the exhibit from time to time, giving special prominence to different features during the sessions of conventions or other gatherings which would be interested in those particular features. As, for example, during the meeting of the American Medical Society the exhibit made by the state Commission in Lunacy of the ancient and modern care of the insane was shown; during the neeting of the American Lithary Association the library exhibit prepared by the State library was installed, and during the meeting of the National sociesy of Charities and Corrections the exhibit of the state Board of Charities was given prominence. In this way practically all of the material taken to Portland was displayed during some period of the Fair. This method provoked a more lively interest on the part of the people of Portland and ricinity in the New York exhibit as with each recurring visit some new feature of the resources of the Empire State was brought to their artention.

To be sure, in a measure this method interfered with entering the State exhibits for awards, inasmuch as it was against the rules of the Exposition company to make any entries for a wari of exhibits which were not in place at the time the juries macle their inspections during the month of September, and it would be manifestly unfair to enter only such material as was dif. 
played at that time to the exclusion of other exhibits of equal merit which were shown at other tines. Moreover, as the entire exhibit had been passed upon in St. Louis by an international jury of experts, from whom it had recoived most thorough consideration and a generous number of awards, and furthermore because it was impossible in the smaller exposition both from the limited resources of the Exposition Company and from the geographical situation of the Exposition to obtain experts in the various groups of the official classification, it was deemed wise not to enter the exhibits of the State for competition, following the same course which was followed by the United States govermment. Therefore, the fact that no record of awarls appears in this report does not mean that none of the State exhibits were deemed worthy of a medal, but that none of the exhibits made under state auspices were entered for consideration on the part of the juries.

A brief account of the exhibits made in the varions departments follows:

\section{Euvcation}

Practically the entire edncational exhibit shown at St. Louis was taken to Portland, the entire scheme of education in the State keing shown in wall cabinets, twenty-four in number, covering the work from the kindergaten to the university, as well as the work that is being done by institutions not purely educational in character.

An interesting set of graphic charts was displayed, containing figures as to the amount of money annually expended by the Enpire siate for educational junposes. To the westemer familial with like figures for his own state. the grand total of forty-one millions of dollars was appalling, particularly in con- 
nection with the statement that this amomnt is mure than one. seventh of the entive amount expended for educaliunal purposes in the Union. The charts also contain the figures npon the value of school houses and sites, amomit. expendrol for teachers' wages, attendance of pupils hoth elementary and secoudary, and the number of students in the higher instifutions of lenrning.

The organization of the State Elucation Departuent was clearly shown by means of photographs. administrative hlanke, and reading matter. The collective exhibit of the kindergurtents and elementary sehools contained may handsome photographs showing both exteriors and interiors of some of the finest school buildings in the State, together with pictures of clisses at work, specimens of work. written work, el cetera, which wor suplle. mented by several hundred rolumes of wiss exercises. The simbe general line of material was shown for the secundary suhouls.

The State normal and training schools-twelve in mumber-likewise the city training schools, and traming chasses in rural districts made interesting exhibits of the work of the state in the professional training of teachers. In no state of the Union is a more elaborate scheme of preparation of lhis kind inrried on than in the Empire state, and the interest of tho educafors of the West in this feature of the exhibit estifich to the ar. knowledged supremacy of New York in this work.

In the university section was an exhibit from Hobart collegt, an interesting feature of which was the astronomical work of Dr. Brooks, who has the distinction of having discovered more comets than any of his contemporaries. Syracuse liniversity made a very meritorions exhibit from the department of fune arts, particular attention being given to the? work of archi. tecture. The exhibit of the Clatkson Memorial suhool of Teed. 


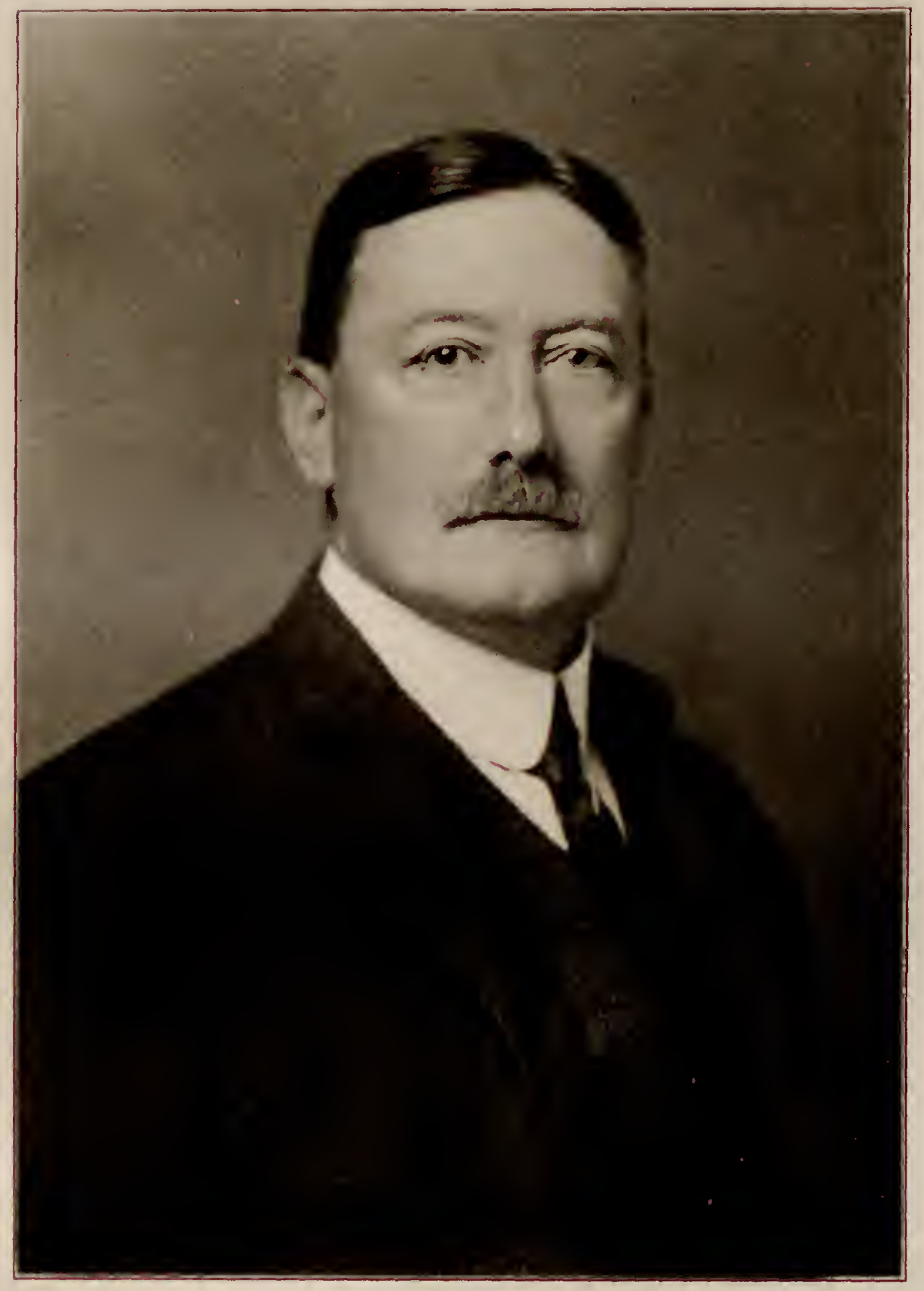

CHARLES R. HUNTTEY

NEW YORK STATE COMMISSIONER 


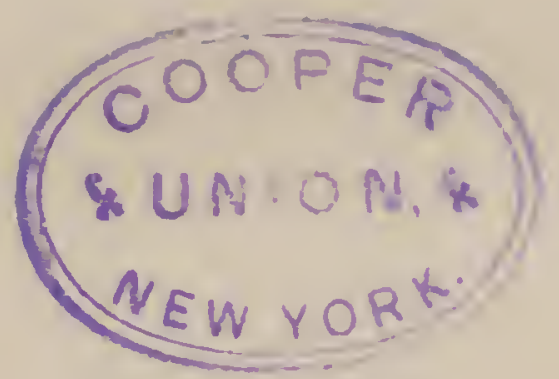


nology at Potsdan, an endowed institution which provides technical training for boys and girls, was typical of the work of the technical schools of the State. An exhibit was also in place from the industrial and trade schools.

The idea of the westerner that the entire State of New York is made up of busy cities and thriving villages was badly shattered when he looked orer the exhibit of the Indian schools of the Empire State in which over 800 Indian pupils are enrolled. It was hard for him to believe that the state maintained thirty-one Indian schools on eight different Indian reservations.

The schools for defectives were represented by the State School for the Blind at Batavia. and the New York Institution for the Deaf and Dumb of New York City, both of which institutions stand in the first rank. Their nlethods for rendering the deaf, dumb, and blind self-supporting were clearly portrayed.

The City History Chob of New Tork furnished an example of work done outside of the regular channels, this institution being designed to create and foster civic mide. A feature Was a collection of pottery made at the New York State School of Clay lropking and Ceranics at Mlfred. which, it is believed, is the only institntion of this nature in the entire Union receiving State aid. Another featule was a handsome model of the new State Formal School at Fredonia, constructed by the students of the institution.

\section{Soctar GCONOMY}

In the depaldnent of social conomy the exhibit attracting the widest attention was that made by the New York State Commission in lunacy. in which the ancient and modern methods for the car of the insane wele shown in a forceful 
way. In the centre of the exhibit hall were prected walls seren feet high so as to form two rooms side by side, one of which was dingy, unattractive and filled with the implements of torture which in the olden dars were nsed for caring for those aflicted with insanity. In one corner stood a massive crib with a grated top on many of the shats of which were plainly visihle teeth marks made by frenzied patients in their endearor to escalp. Nearby stood a restraining chair in which the patient was bound and placed upon a circular platform and spun aromed like a top. The old form of shackles and the old style of strait-jacket were in evidence, and also one of the old gratings which for. merly covered the windows. At the entrance stood one of the doors taken from the Utica Insane Asylum, containing a perp. hole through which the keeper could observe the actions of the patient without exposing hinself of bolily injury.

The adjoining room forcibly told the story of the wonderful progress male in the treatment of these unfortmates. There was every evidence of effort to make it as attractive as possible. It approached in comfort one of our most modern hospital ronms. There was no sign of restraint save that of a modern canvas strait-jacket, which was placed in an inconspiruons corner. In wall cabinets on the outside of the walls of these rooms were many pictures of New York's model institutions of this kind as well as statistics bearing upon the care of the insane and the per capita cost of their maintenance.

The exhibit of the State Board of Charities consisterl of wall cabinets containing photographs, aduninistaltive blanks and printed matter. The section devoted to the care of destitute adults contained photographs of the valious almshomses in the State and statistics as to their cost, wresent rulur. capacity. 
et cetera. In the departuent for the care of jurenile delinquents, in addition to the features just mentioned, were also models of work dome ly the inmates, a feature of which was a handsomely caled seat which was made by the boys of the Honse of Refuge at Randall's Island. The section devoted to the care of needy families in their homes inchuded a comprehensive axhibit made by the charity Organization Society of New York.

The State Department of Labor exhibited a set of graphic charts showing the wonderful coumereial development and sufremacy of the Empire. State. These chats not ouly compared New York:s position with that of other states of the Union, but also with many of the mole progressive foreign comtries of the worll. Fom nomographs were woitten hy experts upon the following snbjerts: "Typiral Employers' Welfare Institutions in New York." "Labor Legislation in New York," "Work of the Departuent of Iahor" "and "Growth of Industry in New York." These monographs were distributed free of clarge and were in great denand by those who were studying sociological problems.

The exhibit of the state hepartment of Healili consisted of photographs of the State Department oflices, the Anti-toxin laboratory, sewage disposal plants. ete. also administrative blanks and yamphlots bearing upom the enforcement of the lealth laws of the Statc.

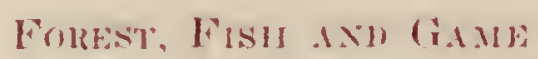

The forest, fish aud wime exhibit was alsu a soure of wonder to the people of the Mest. who were invariably incledulous when informed that a quarter of the state was wild land. and that many thousand deel have benn taken from the Adirnmaliks during at single ophell k'ason. 
At the west entrance of the state building stood on either side of the doorway a huge grizzly and a handsome lunck. An aged visitor as he passed the grizzly was heard to exclatim, "They would not have us beliere thẹ have them things in New York, would ther?" While humorous to a New Yorker, thr remalk forcibly summed up the attitude of mind of a large mumber of people in the Test upon this subject.

Covering the walls of the exhibit lall was a handsome collec. tion of the birds of the State. many of them rery rare, and some fer extinct at this time. There was also a gromp of momuted fish taken from the waters of the state. It was the only cxhihit of the kind shown at the Exposition and a source of muending interest to tlie sportsman.

Another feature mas an exhibit of the woods of the state which was prepared some time ago ant considerable expense. It showeal a photograple, taken in the summer and also in the wimler. uf earch tree, a specimen of the bark, also the leaves, and likewise tangential, radial and tranverse sections rut so thin as to be trans lucront. thus displaying rery clearly the natme of the fibre.

The walls of the reception room and the dining room were hung with pictures of some of the most attractive forest scenes in the State, including views taken in the Adirondacks, the Catskills and the Thousand Islanils.

\section{SCIFivi:}

In the scientific exhibit were shown in jals seseral spropimens of the mineral resources of the State. particulal attention being given to salt, cenent and other commereial products. 


\section{Horticuratue}

The distance from home precluded the possibility of making any exhibit of fresh fruits, which is to be regretted, as the fruits which most nearly approach those of New York in flavor are those which are raised in the state of Oregon.

The ouly exhibit made in the repartment of horticulture was that made by the Urbana Wine Company, which showed an attractive cabinet of Gold Seal clampagne.

The entire State exhibit in education and social economy was turned over to the Commissioner of Education at the conclusion of the Fair, by whom it has been installed in the fourth floor, Senate corridor: of the Capitol at Albany, to form the nucleus of a permanent perlagogical museum. The forest, fish and game exhibit was returned to the Forest, Fish and Game Commission by whom it was prepared. 



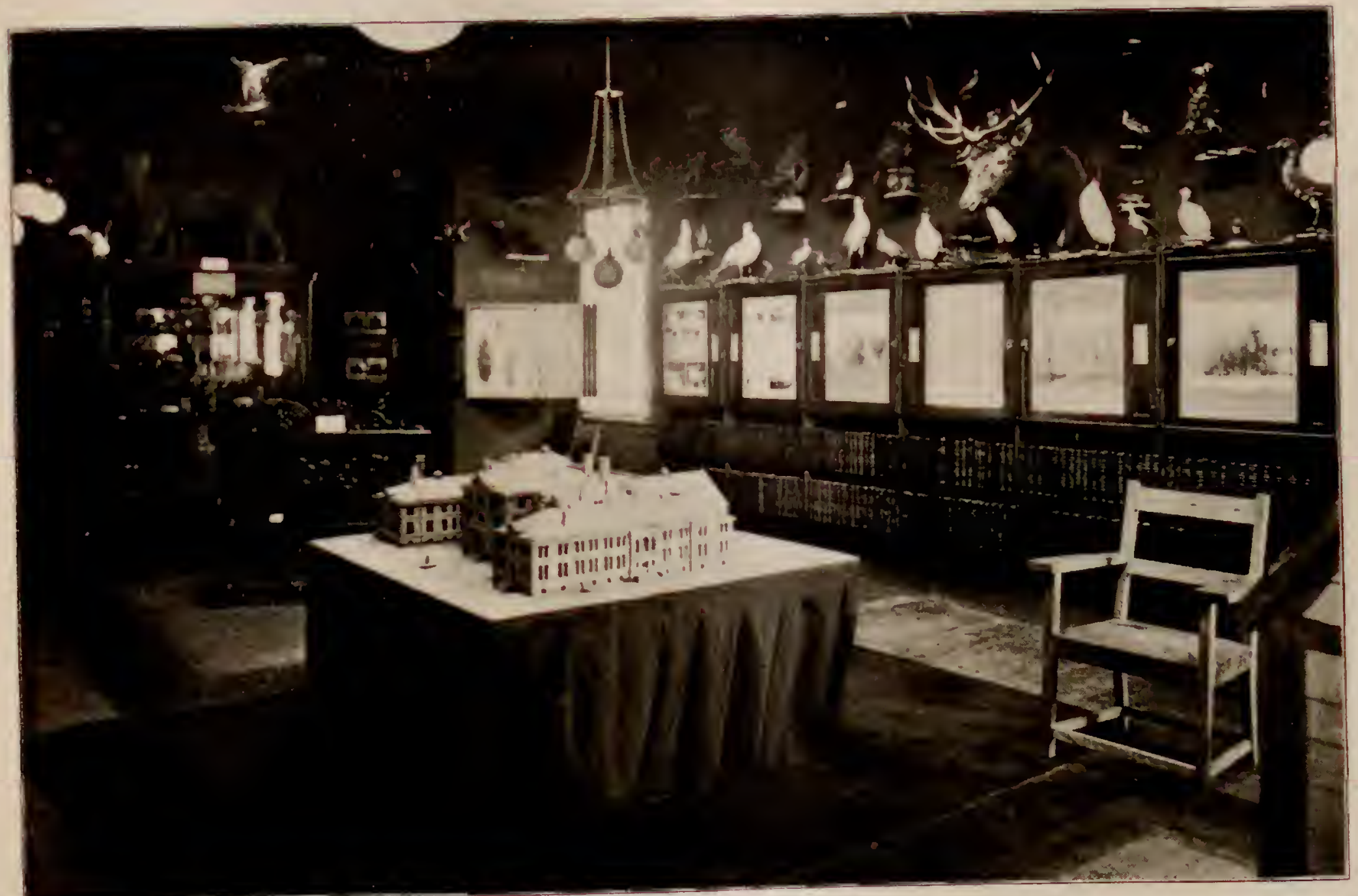




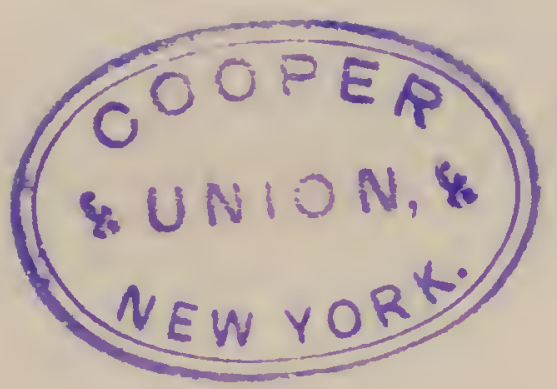


CHAPTER Y

Social Events 



\section{SOCIAL EVEN'TS}

E ROM the opening day of the Fair, the New York State building became the social centre of the Exposition. Believing that such action would meet with the approval of the people of our State and would be exploitation of the best kind, the State Commission offered its use to the Exposition authorities for any official functions they desired to hold there, provided always such use did not interfere with any plans made by the New York Commission for the entertanment of her prominent citizens or other distingnished guests. Inasmuch as no place had been provided for this purpose by the lixposition directors, the offer of the Commission was accepted, and the state was brought into additional prominence and received many compliments from those who were entertained within the walls of its building as the guests of the Exposition Company. Moreover, the use of the building was frequently requested by commissioners from sister states, govermment officials and others during the season, so that there was never a week throughout the entire Exposition period but some function of importance was held.

Below will be found a brief list of the functions held at the building.

June 1st, Opening day.-Vice-President Fairbanks, the congressional delegation, the directors of the Exposition and distingnished guests were escorted to the New York building by a large detachment of infantry, cavalry, artillery and civic bodies at $10: 30$ А. .. Ifter a brief rest, the entire party walked across the lawn to the grand stand for the opening day exercises. At 
their conclusion they returned to the New York building where a Inncheon was served by the Exposition management to about 300. At 7 o'clock a dinner was given by the Exposition minage. ment in honor of Vice-I'resident Fairhanks and the congressional delegation, which was followed by a reception in the New York building and the pavilion annex. The prominent gruests included Vice-President and Mrs. Fairbanks. Speaker Cannon, the Gorernors of Oregon, Washington, California and Idaho, several United States Sentitors and Members of Congress. Commissioners Luce and Brown were present. Special fireworks were riewed from the rerandas of the State building.

T'uesday. June 6th.-A luncheon was given by President Goode to the members of the Transcontinental Passenger Association. Abont 60 guests were present. President foode was toist. master and toasts were responded to by Mr. Janes Charlton, president of the Association; A. M. Cleland, general passenger agent of the Northern Pacific R. R.: C. L. Stone, general Massenger agent of the Great Northern Railroat; C. S. Fre, of the Sonthern Pircific: W. I). Wheelwright, president of the Portand Chamber of Commerce, and others.

Friday, June 9th.-Dinner given by the New Jork Comminsion in honor of the President of the lixposition and If Is. (imale. Covers were laid for 70. Music was furnished by the Administration orchestra, assisted by soloists from Innes band. The floral decorations were American Beauty loses and ferus, many fairy electric lights being used. Commissioner Pratt A. linown presided, remarks being made by President Goode, Hon. George H. Willitus, Mayor of Portland, Hon. Theodore B. Wilcox and others. Commissionel Altman was also present.

Monday: dune 12th.-All evening rereption was given by presi. 
dent Goode in honor of the California Promotion Conmittee. About 300 guests were present. Refreshments were served and the Administration orchestra provider the music for dancing. Commissioner Brown was present.

Tuesday, June 13th.-A dinner was given at $7 \mathrm{r}$. M. by the New York Commission to the Yale men of Portland. Commis. sioner l'ait A. Brown presided. About 30 guests were present. The table decorations were bachelor buttons and riolets.

Wednesday, sune 1,th.-Luncheor at 1 o'clock by the New York Conmission in honor of Mrs. Oskar Huber, wife of the Director of Works of the Exposition. Covers were laid for 20 ladies and the guests were received in hehalf of the Commission by Mrs. Pratt A. Prown, Miss Marjorie Lace and Mrs. W. W. Brow.

Informal clance in ! 1 . M. by the New York Commission in honor of Miss Marjorie Luce, daughter of Commissioner Clarence Lince. About 40 guests were present, who were received by Mrs. W. W. Brown and Miss Latee. Musie was furnished by the Adninistration orchestral and light refreshments were serred.

Thursday. Jume 15th.-Luncheon at 1 o'elock given by the Oregon State Commission in connection with the ceremonies incidental to the dedication of the Oregon state building. The guests included the Oregon State Comnission and representatives from rarious states. Commissioner brown was present.

Fridu! dune 16th.-Tlre active state commissioners, executive oflicers and foreign representatives met at the New Iork building at $4 \mathrm{r}$. $\mathrm{x}$. for the furpose of forming an executive commis. sioners association. I temporary organization was effected at this meeting.

Monday, June 19th.-A dimner was given by tha New York 
Commission at 7 r. M. in honol of Ton lewis. Mirectol of Alechi. tecture of the Exposition. Commissionel l'ratt A. Brown pre. sided. Remarks were male hy Mr. Lewis. Hon. Theorlore B. Wilcox and Mr. C. W. S. Wood.

Friday, June 23d.-A luncheon was given by the President of the Exposition at $10^{\circ}$ cloch to the Inigation Commission ap). pointed by Congress Which was Iravelling through the llest investigating irrigition problems. Covers were hid ful fll. At the conclusion of tho luncheon the entire panly was tathen

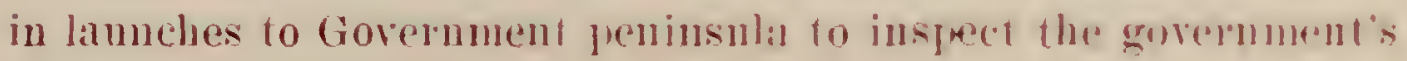
irrigation exhibit.

Tuesday, June 2ith.-Luncheon given hỵ the New lorti Com. mission at 1 oclock to ladies of Portland. Covers Were laid for 20. The guests were receival in lubalf of the rummis. sion by Mrs. Delancey M. Jillis. The table decorations were white sweet peas and cosmos.

A luncheon was given by l'rexident cionde al 1 nieforli in honor of Frederick Inues, the leader of Inues band, whill wat about to close its engagement at the lixposition.

Reception by President fioode from ! to is in lonno uf the National Editorial Association. Eight lmmllerl invitations were issued, and editors were present from all pallts uf the ( nion, especially large delegations being fresent from llw "istroll states. The guests were receiver hy President and IIrs. (ioode, Mr. and Mrs. I. Allen Lewis, Hon. and Mrs. George W. Mr livide, Mr. and Mrs. Theodore Hardee, Mr. and Mrs. 1), M. Iillis. De. Caprios orchestra stationed in the gallery of the rotunda fur.

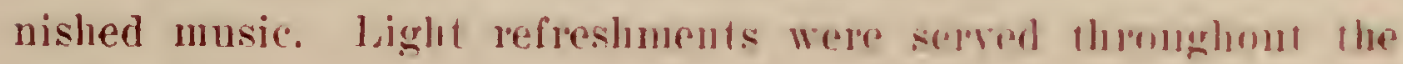
reception.

Saturday, July 1st.- In informal dance and rhildlents fally" 
was given by President Goode from $7: 30$ to 10 P. м. in lionor of the birthday of his daughter. Many young people were present. The Administration orchestra furnished mnsic for the dancing. Light refreshments were served, and fireworks were viewed from the verandas of the building.

Sunday, July 2d.-A dinner at 7 r. M. given by the Italian cousul, the commissionel from Italy to the Fair, and Italian residents of Portland in lionor of the officers of the Italian crniser "Umbria." then in port. The distinguished gnests included Governor Chamberlain. President Goode and others.

Tucsday, July 4th.-Several informal dinners were given in the State building. Rabbi Emil G. Hirsch of Chicago was tendered a dinner by friends of Portland, covers being laid for 30.

Miss Mary Isom gave a dimner in honor of 20 risiting librarians attending the session of the American Library Association.

President Goode gave a small dinner at which were present Commissionel and Mrs. Williams and Mr. and Mrs. D. M. Ellis of the New York Commission.

Wednesday. July 5th.-1 small luncheon was given by Com. missioner and Mrs. Harry D. Williams in honor of Congressman and Mrs. Merbert 1. Parsons of New York City.

A reception was given at 9 1. a by the New York Commission in honor of the various state commissioners and govermment oflicials. Four hundred invitations were issued. The guests were received by Commissioner and Mrs. Harry D. Williams who were assisted ly President and Mrs. Goode. Music was furnished by Decaprio's orchestra for dancing, and light refreshments were served dming the evening.

Friday. July ith.-Reception at 9 r. s. by the New York Com. 
mission in honor of the New York State society of Oregon. The guests, who inchuded a large mumber who had left lew lork to seek their fortunes in the West many rears heforr. were received in behalf of the Commission by Commissioners and Mrs Harry D. Williams and Hon. George H. Williams. President of

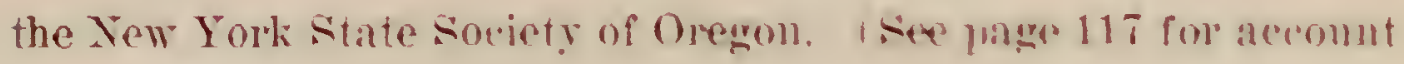
in foll1.)

Wednesdry. Iuly 12th.-I dinner was given by President Goode in honor of Governor Myron 'T. Herrick of Ohio, and Gorernor B. B. Brooks of Wyoning. Mesides the guests of honor. there were present Governor Pardee of California, the juet of the Sierras, Joaquin Miller, and other frominent personages. Covers were haid for 50 .

Saturday. Inly 15th.-Through the courtesy of the lixpusition management a concert was given from $4: 30 \mathrm{r}$. $\mathrm{M}$, to ti $\mathrm{l}$. w. at the New York building by the Indian hand from the gorelument school at Riverside, Califormia.

Monday. July rith.-A Inucheon was remdered ly President Goode to Governol E. Y. Sarles of North Dakota. The guests included Dr. and Ifr. S. B. Ward of the New York rommission.

Dinner at $S$ r. ur by the North Dakota Commission in honor of Governor Sarles and party. Dr. and Mr. S. P. Ward wew among the invited guests.

Thursday, July 2rth.-Breakfast at $120^{\circ}$ alock ly .If s.s. Simuel B. Ward to several Portland ladies. The table docorations were roses.

Saturdey duly 29th.-Dinner at s:30 P. M. ly the New York Commission in honor of the forernor of Oregon and Mis. Chamberlain. Covers were laid for 22 guests. The lecolations con. sisted of a profusion of paluns and white flowers. pink shaded 
candelabra being used with good effect. The guests were received by Dr. and Mrs. Samnel B. Ward.

Monday, August Tth.-Dinner at 7 o'clock by President Goode in honor of Hon. Edward H. Harriman and party. At the conclusion of the dinner, launches were taken for a ride on Guild's lake.

Saturday, August 12th.-Dinner at 7 o'clock by the President of the Exposition in honor of Hon. John Barrett, United States Minister to Colombia. Covers were laid for 25.

Thursday, August 17th.-Luncheon at 1 o'clock by President Goode in honor of IIon. Alfred Bayliss, personal representative of the Governor of lllinois. Covers were laid for 40 . The guests included Dr. and Mrs. S. B. Ward and Commissioner and Mrs. Charles R. Huntley.

Frida!y, August 18th.-Dinner at $7: 30$ by the New York Commission in honor of Lientenant-fovernor and Mrs. M. Tinn Bruce. (See page 86 for full aceount.)

Saturday, August 19th. Yeu York stute Day. (See page 95 for full arcount.)

Sunday, August 20th.-Dinner at 7 P. M. by the New York Commission in honor of the New York official delegation. Commis. sioner Huntey presided in behalf of the Commission. Covers were laid for 30 . In addition to Commissioner and Mrs. Huntley, were present Dr. and Mrs. S. B. Ward and Commissioner Henry Altman.

Honduy. Angust 21st.-Luncheon at 1 o'clock by President Goole in honor of frovernor Mickey of Nebraska. Covers were laid for 30. The gnests included Dr. and Mrs. S. B. Ward and Mrs. I) M. Ellis.

Dinner at 7 1. 11. ly Vehraska Commission in honor of Gov- 
ernor Mickey. 'The guests iucluded the ofticial party of the Gor. ernor. Covers were laid for 15.

Tuesduy. August 22d.-Dimer at 7 r. . m. by President Goode in honor of Governor MeDonald of Colorado. Covers were laid for 35. The guests included Commissioner Henry Altman.

Thursday, August 24th.-Dinner at 7 P. a. by President Goode in lionor of Governor Cntler of Utals. At the conclusion of the dinner the guests took launclies to witness the sham hattle npon the lake.

Saturday, Angust 26th.-Dinner at 7 r. 3. by President Cinode in honor of Governor Pardee of California. Covers were lais for 60 .

Wednesday, September 6th.-Reception at 9) r. m. by President Goode to the California Legislative Committee. Special fireworks were witnessed from the rerandas of the state building and light refreshments were served.

Thursday: September Fth.-Informal dance given hy Captain Ralpli Ingram and officers of the Tentlu Infantry, U. S. A. Musir was furnished by the Tenth Infantry band.

Friday, September Sth.-Dinuer at 7 I. ar. by President Goode in honor of Governor Gooding of Idalio.

Tuesday, September 12th.-Reception at ! r. M. tendered by President Goode to risiting electrical engineers. Light refresh. ments were served.

Wednesday, September 13th.-Dinner at 7 r. s. given by Presi. dent Goode in honor of Governor Joseph W. Folk of Miscouri. Covers were laid for 90.

Monday, September 18th.-Luncheon at $10^{\circ}$ clock by loresident and Mrs. Goode in honor of officials of the Lonisiana Purchase Exposition. 


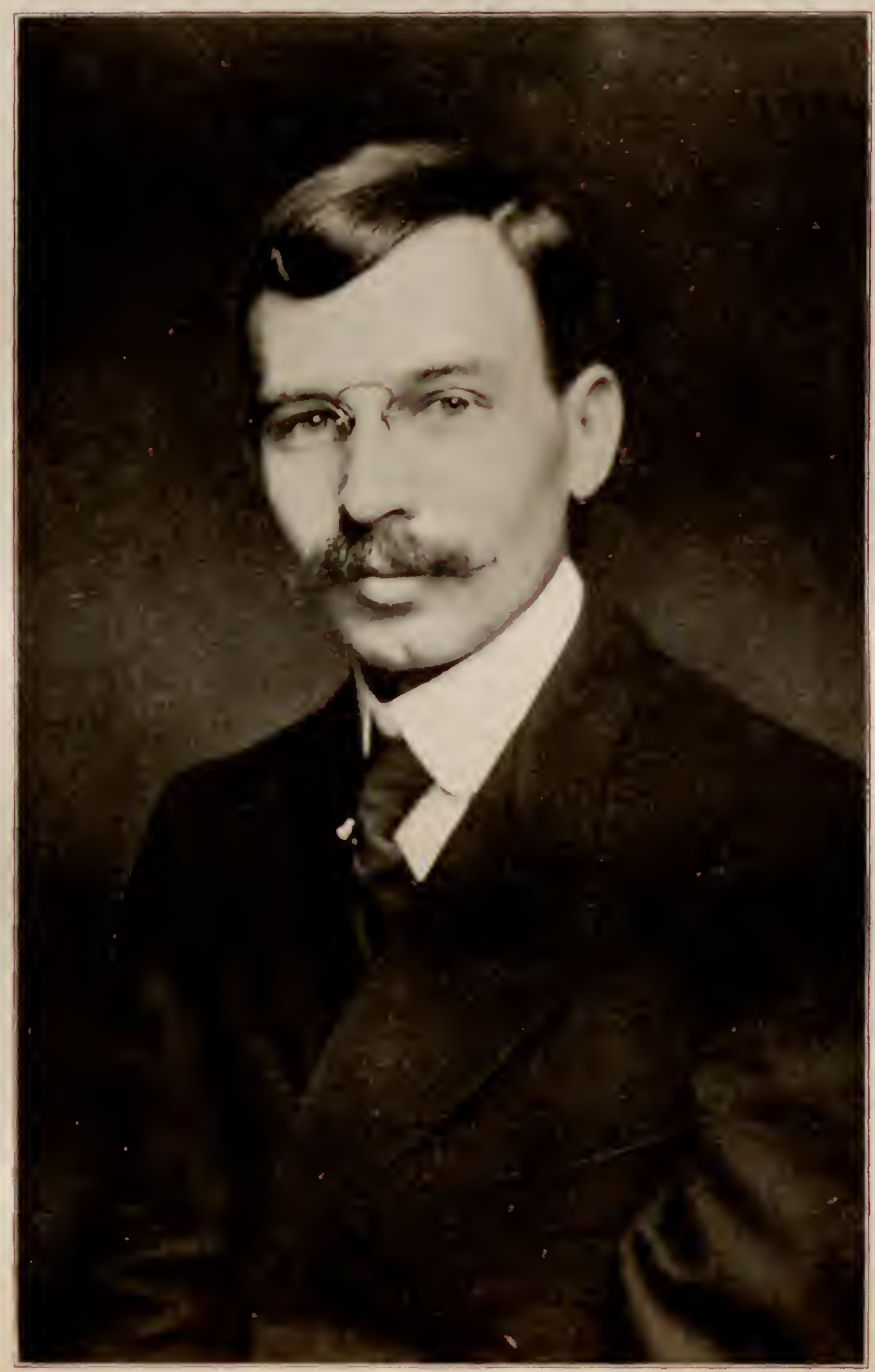

I) 1. IACEFY W. ELLIS

I.X101TH, UFFICER, NEW YORK STATE COMMISSIUN 

Weducsda!l. Septrmber 2ith.-Dinner at 7 r. 3. given by President Goode in honor of Governor Mead of Washington. Covers were laid for 60.

Tuesday. Oetrber 10th.-Dinnel at 7 r. M. by the New York Commission in honor of the ladies of the Sacajawea Statue Association. Commissioner Menry Altman presider. Covers were laid for 45 .

Thursday. October 12th.-Dinner at $7 a^{\prime}$ clock given by the New York Commission to the members of their staff. Commissioner Iltuan presided. Covers were laid for 14.

Saturday. Oretober 14th.-Dinner at 7 oclock by the Board of Directors of the Exposition in honor of President Goode.

Dinner by Mrs. Goode to a brty of friends, Commissioner Altman by invitation acting as foastmaster. Tater in the evening the parties joined and proceeded to the band stand where the rosing exercises were hell.

In addition to the above, a number of mofficial functions were held, no mention of which can he made in this report. hut each of which furnished additional testimony of the popularity of the New York huilding. 
CHAP'TER VI

New York State Day 



\section{NEW YORK STATE DAY}

CATlinda dugust 19th, was set aside by the Exposition au-

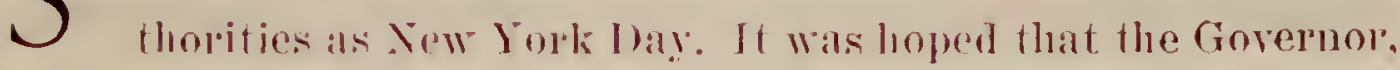
Hon. Frank 11. Miguins, would fund it possible to be present upon that oceasion, lunt a plessure of ofrobial duties coupled with

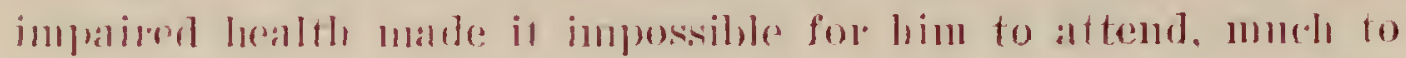
the regere of the commisitom amb to the people of the coast, to whom he is woll known. No mone salisfactory substinte condd liave been ilosen than Hon. M. Liun Broce, the TientenantGovernor. Who. Wibl Mrs. Bruce, alrived in Porthand on the

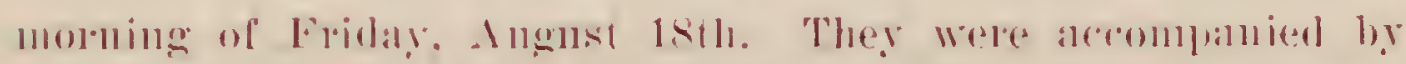

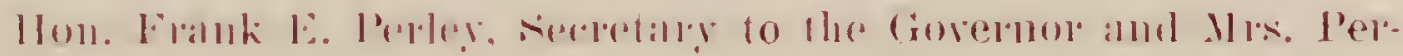

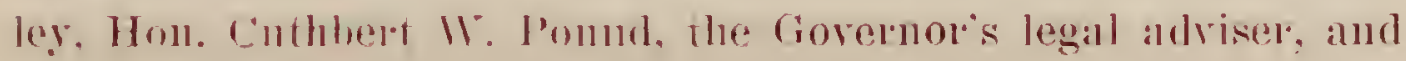
Mls. Ponl1el.

lipon arival theg were diven at once to the New lork state milding where rooms lath beon reserved for them during their sojomlu al the Exposition. ()n the afternoon of the sime day, the legislative delewation realded l'olthand, and wele driven im-

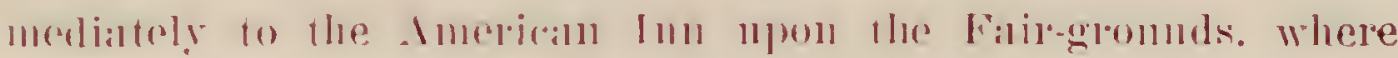
ample alcommondations were plared at their disposal. The delegallion inclunted Hon. S. Foed Nixon. Furater of the Assembly,

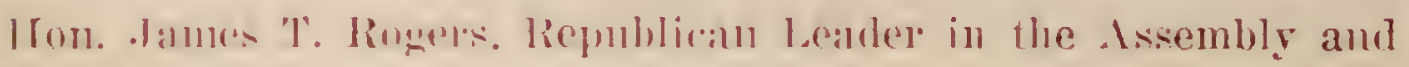

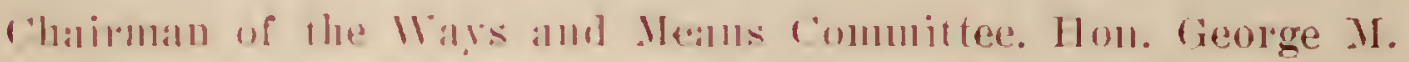

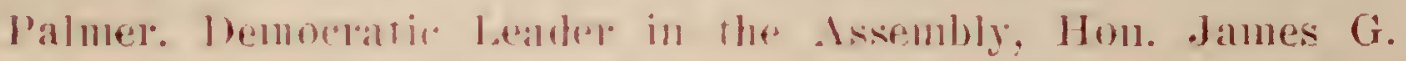

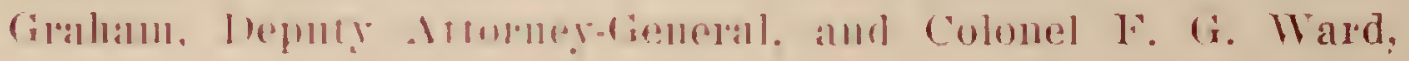


Superintendent of Public Works of the city of Buflalo. "litere were also present as the guests of the Commission. Conglessinan and Mrs. Williams. Lennett, of Nem lork Gily.

A large force of men from the Expositim Department of llorks Ind lavishly decorated the state holding hoth inside and out. American and Exposition flags were festoonen at each window and hung in graceful folds upou the walls of the reception room and dining room. These were supplemented with ropes of Oregon grape and evergreens which were twined about the pillats and so festooned in the rotunda from the baleomy as on comvert it into a veritable arbor of green. The entire capense of decorat tion was bolne by the Fxposition Company, which. as well as in many other ways. demonstrated its appreciation of the batro ticipation of the limpine siate in the Exposition.

The furst function in connection will the observance uf Siew York State Day was the state linnel given ly the Commissim

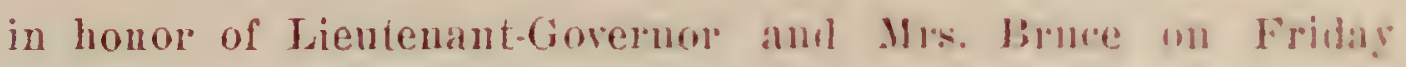
evening, dngust 1Sth. Covers were laid for 70. the diunel being leeld in the latrge dining room. The lable was in thr shapro of a letter $C$; the seats of the gmests of honol being so flated as to make the magnitirent illuminatous about lho gromme plainly

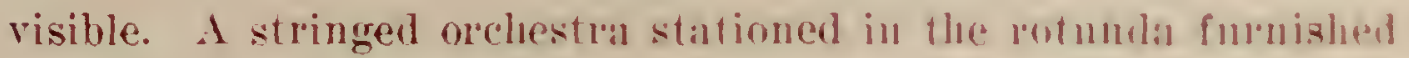
music for the occasion.

Dr. Sammel B. Ward. Vice-President of lhe Vommission, fled sided. and esconted Mrs. Iirmec, who was seated upon his left. the Lientenant-Goreruol being seated npou his right. It the conclusion of the menu, informal foasts were lesponded fo his

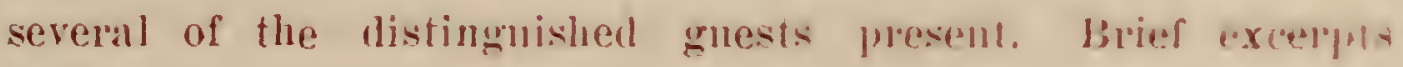
follow: 
Hon. M. Jinn Bruce, Lieutenaut-Governor:

"President Ward, I wish to express to you, sir, the grateful appreciation of Mrs. Bruce and myself for this delightful courtesy, and I wish also, sir, on behalf of the Governor and the people of the State of New York to congratulate you and your colleagnes for the energy and enthusiasm with which you have executed the commission placed in rour hands by Governor Odell. I also appreciate that it is because of the delightful generosity of President Goode and the other members of the Exposition Company llat New York has been permitted to ocenpy such a prominent place in this gem of an Exposition

"No man ram darerse this rontinent, no man ran visit th is coast withont boing a better American. 'There ran be no little Ameridans here. Fvoly man who has had the delightful opportunily of viewing the boundless expanse of our common country must be impressed with its wonderful proportions. and. my frends, that is the orelwheluing sentiment that consumes me as a traveler making his tirst visit to the coast. I an impressed with the powel and potentiality of the United States of America. I an impressed with the high mission which providence in His wisdom has called upon us to execnte. I am impressed with the great responsibility placed upon ns of planting upon this continent free institutions and hoinging people all over the world into closer relations throngh the allministration of peace and great hlessings of civil and righteons liberty. I an much gratified indest to ho here to-night in this grand State of Oregon. which is the molel silale of the wreat Northwest, an empire in itself, in whirl there has leon bromght forth in the few years of its existence a vivilization which is the wonderment not only of our countreg. but also the rivilized world." 


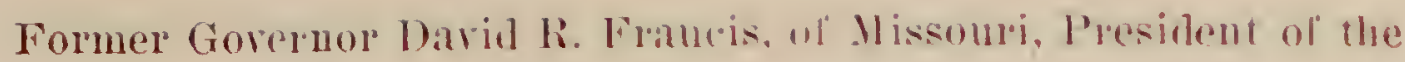
Tonisiana Pmrchase lixposition:

"I am very glad of this opprortunity to express un hehall of the people of the Midalewest. al least, their alpurerition and their obligation for the very helpful aid renteren flem in their undertakings by the people of the state of New lork. 'llie Empine State of the Union responded to the appeals of St. Jouis and the Middlewest last real" when the popple of the Lomisianal Territory celebrated an international and muiversal exposition in commemoration of a great event in the world's history, and we are coming to the Pacific slope in this yeall. l!)(t). (0) visit this marvelous exposition, and we find the pople of the limpire siato have responded cheerfully and rory helpfully in the alpueals you have made to them. So that, whether these celebrations of

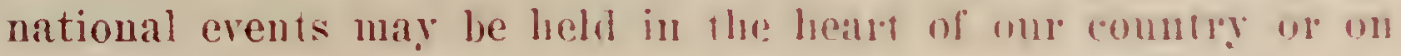

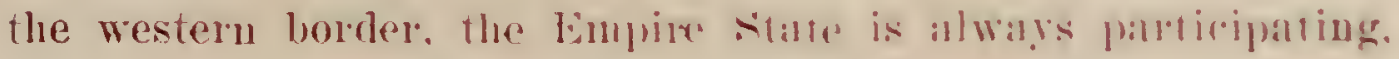
and wherever she is, there is the head of the lathle.

"I am sure, therefore, that the penple of the lewis aml riath

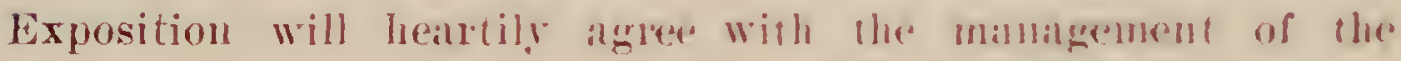

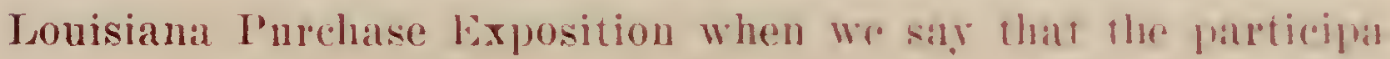
tion of the Empire State in these middle and "xtrme westron celebrations serves but to cement still closer the imople of the Pacific coast as well as the feople of the Misisiphi valley with the people of the Illantic const.

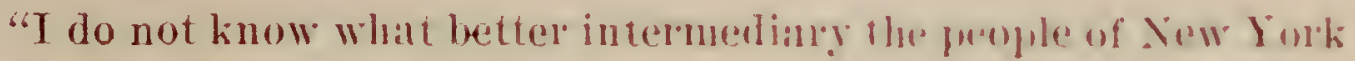
can nse to shake hands with the people of the cobst than the preople of Missomi, and wo who alle on the banks of the fonthe of watces.

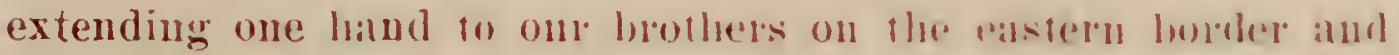
the Empire State and another hand to the Pareific slope. Hot only

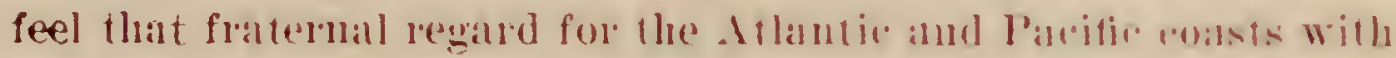




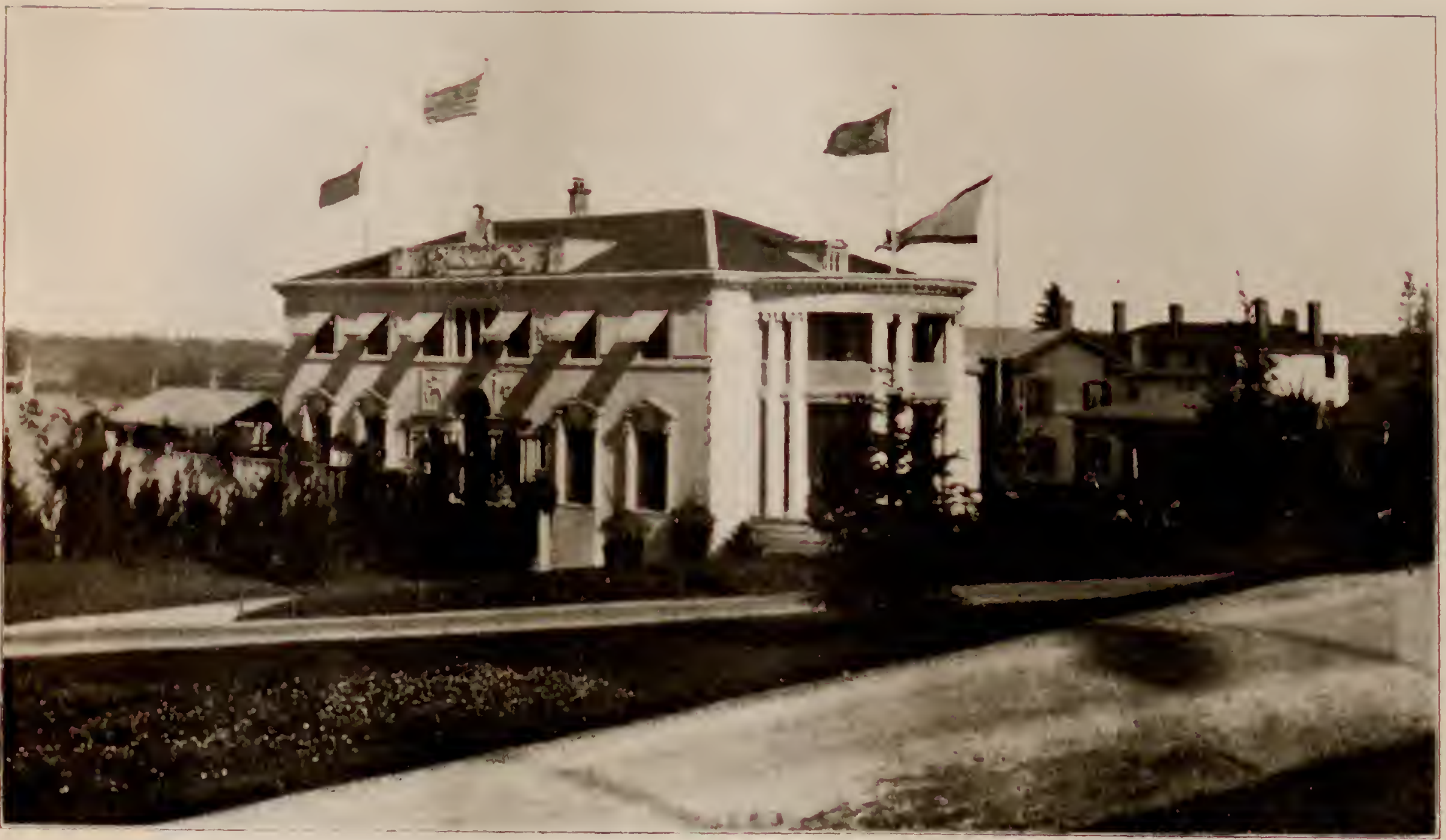

NEW YURK STATE BLHMNG FROM SOTTHWEST 


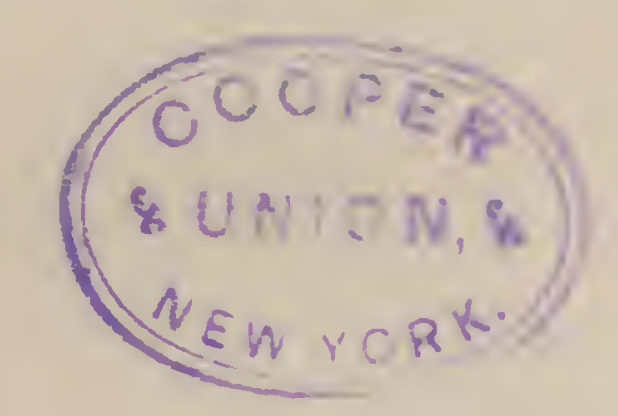


which nature imbues us, but we can, I lrust, draw into still closel rommunion with the people of the Alantic coast and the people of the Pacific slope. May this Exposition, participated in as it is by states of the Alantic, the states of the Mississippi valley and the states of the Pacific slope, serve but to make us better acquainted each with the other, serve to strengthen our fraternal regard and above all things serve to deepen our patriotism."

President Goode:

"No state hatt has participated in this bxposition has rendered greater assistance than the State of Yew York. Its participation las been delightful, and its representatives have entertained us royally. We lave tried to returu the comresy by entertaining then as fal as we conld. To-flay we have an alditional honor in the fresence of Governor lince and his party. I wish to thank hin for the trouble he has taken to come here to see our Exposition and to take part at the exercises on New Jork Day, to be held to-morrow. I extend to you, sir, a very heaty welcome."

Hon. James T. Jiogers, Republican leader in the Assenbly:

- I malrel (o think what a gleat conntry we live in. How wourlerful are its resources and how strangely we lave been brouglit fogethel: Entil we had made the rip across the continent. little did l realize the distance which seprlated ns, little did I lealize the length and breadth of on conntry. I few short days ang. the tervitory between the oceans divided 115. and ret we are here to-night fraternizing as if we had known calch ofher for a life tines and regletting that we latre not. 
"Polities in the Last" I think was the topie assigned me. 'Traveling as we have been for the hast fire days molere another flag. listening as we have heen will rourtems interest to the discussions of political anlinirs by the loyal sub jeets of the King. we have beral somewhat reminded of the fact that our political differences al a after all trifling dif. ferences. While they may he in many pexpects much allu abont nothing, after all the one tendency in which we maty all rejoine is that out of it all there is an mplifting and there is a broblening of the intelligence and of the reasoning powers and of the integrity of onr ritizenship which bodes only grood for dhe dilys that are to come. * * * Polities in the List is learning the lesson from the West, the North and fhe sombl flat what is good for one is good for all, and what injures the least. likewise

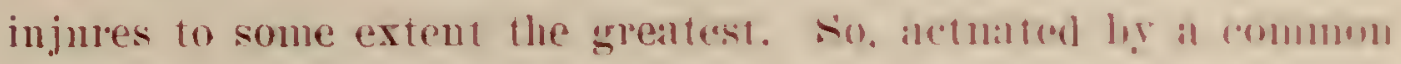
impulse, we are tending constantly to hoste Letrer days when we shall realize that the best that we can give for onl comntry or our State is the best lhat we ran give for mor fanily, onl homes and ourselves. for we are learning there as alsewherw lhat

- Life is the Emprive of King allul slate

It is just what ron atre and do:

Then give to the world the best rom hase

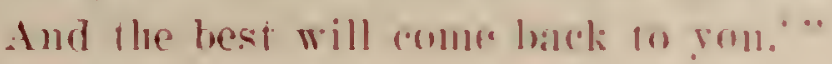

Hon. S. Fed Nixou, sipealere of the Isombly:

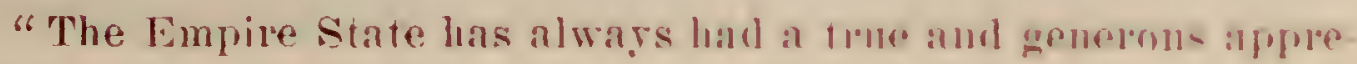
ciation of the responsibilities derolving "1pm it. M० law al way

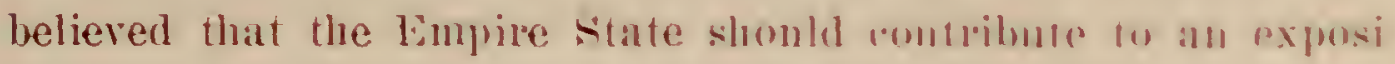
tion which is the exponent of the development of the antire untited comtry. Xew York State appreciates her position. Sle appre. 
riates the fact that her power is dependent upon the glory, and upon the development of this mation, and that an exposition like this helps to develop the industries of the nation. While she may be the financial centre of this continent. she is dependent for liel commere and for her smpremacy npon what she may le offred from the extrene West and Middlewest.

- lle ask not for the devolopmont which simply means local injowemril. we ask not for the development which simply means the advancement of thr Fist. hut New York as the commerrial and financial center of the Enited states is in sympathy with

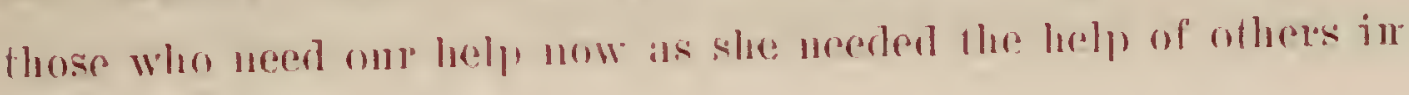
rats gure lis.

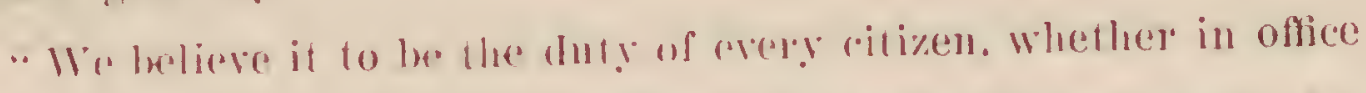
111 1111. to perform his obligations in a way which will make for the mplifting of the mmireipalit! or the civil division in which he rexides.

"Theme is only" one position for all of us fo ocenpy and that is for us to proform whatever Anty may be incombent mpon us just as well as we mal kuow how on lo. and while the millemnimm may mot arrive within onr day and time, it will he much nealder this guneration than it has bern in the preceding genemations.

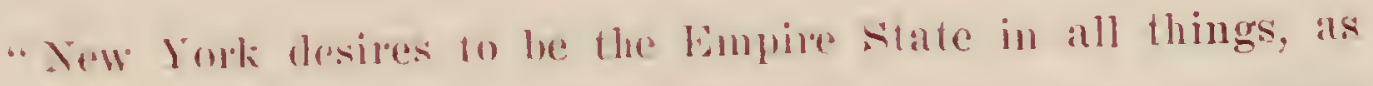
she is the bumple state in wealth and population, and gou will find her in the future as in the past alwags willing to rospond in any Way that maly make for the uplifting. for the Henefit. for thr alvanement of her sister states. and especially fur anything lhat ma! make pol the advancenent and uplifting

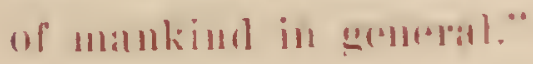




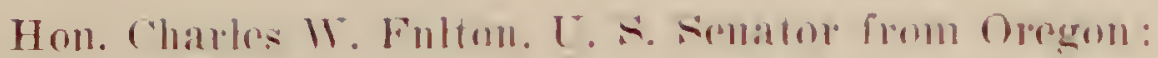

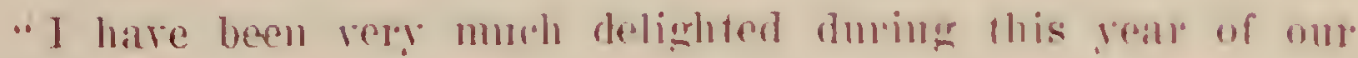
Exposition to meet the gentramen from the liast and to sero the interest that they have taken in the dowelopment of the Mest, and none of them. I think, hate rxhihital a more lively introse than have om friends from the Empire State of New lokk. They hate come here and have ereded a splemdid holding and they have

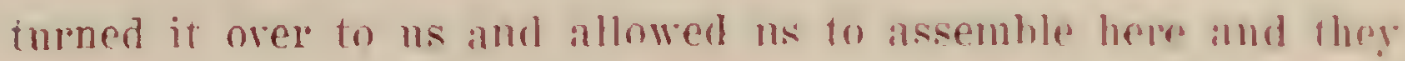
have extended the watmest lospitality to us. and wa lwegin to feel after association with mol foimds fom Now Jolk that affor

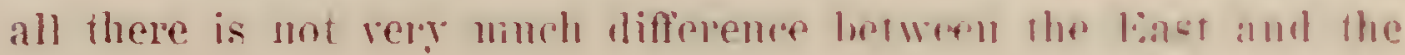
West.

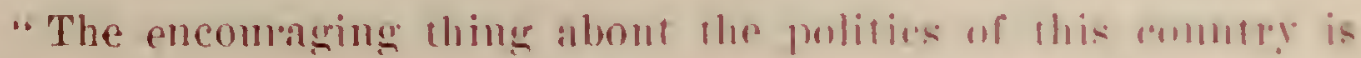
that the people are getting rosep logether all the limb. The subjects which interest the people of thr Fast are the subjects which interest the people of the Irest. The high inlests which inspire the East are the same ideals which ilspirm the llest.

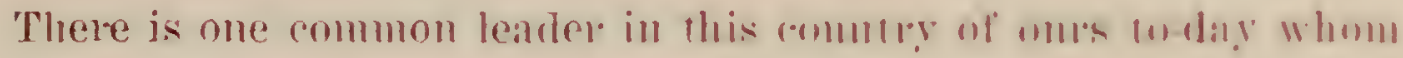

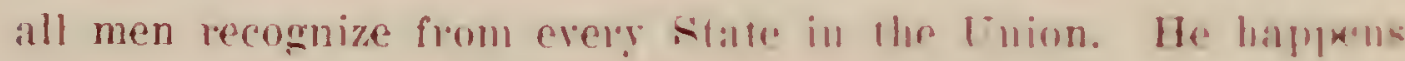

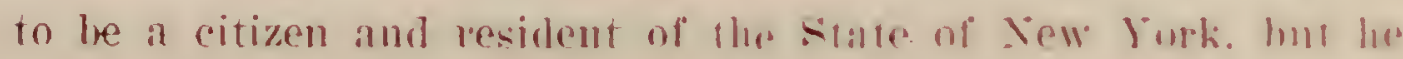

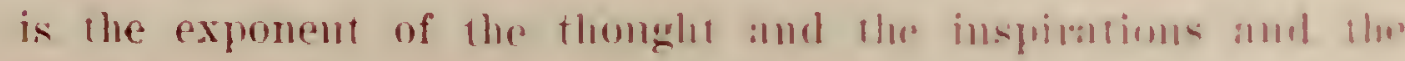
ambitions of all the people of all the staldes in lho alvallerment

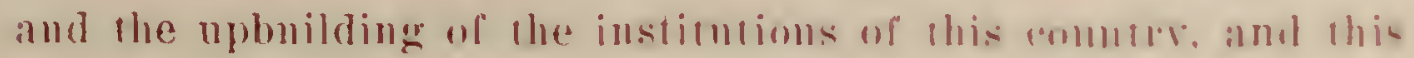
man is Theodorr Rooserell."

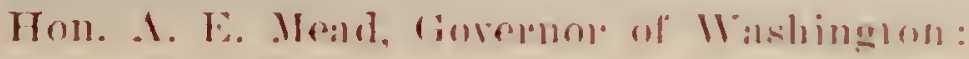

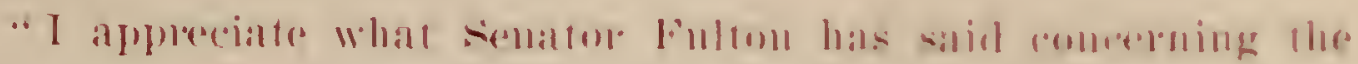

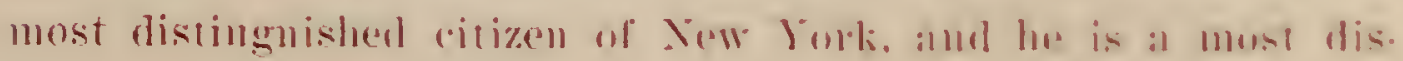

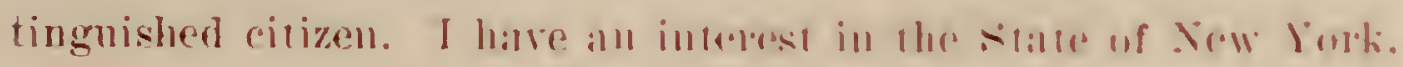

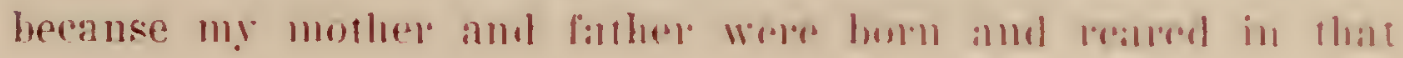


stale. They moved west in the ants. I have been moving along with them since. It is a source of great pleasure to me to meet you in this banquet lall, and to know something of you. I trust during youm visit upon the Pacific coast you will visit the state of Washington, that you, will know something of the hospitality and the enterprise of its people, representing the youngest state of those that are represented here."

Hon. George H. Williams, Former Wayor of Portland:

- I lave had the ploasure heretofore of meeting in this building serenal distinguished representatives of the State of New York, and I have the lonor as well as the pleasure this evening of merting distingmished representatives of that state, the State of my hativity. Whloerer a man may be or how much he may be atfached to the land of his adoption, there will always linger in his memory a fond recollection of the place where he was born, and the scencs and associations of his early life. Our foreign population, and especially our German fellow-citizens refer to the comntry from which they emigrated as the Father. land-a word full of rich signiffance lrecause it speaks of father, Imothor, relatives and friends, and of all those tender ties which inspired the poet to sing :Home, sweet Home, Be it ever so humble, 'There's no place like Home. When I left my father's honse. I came to the then distant territory of Iowa, and after some fears there, I came to the more distant territory of Oregon, but in every removal I have dragged a lengthening chain from แIy liumble home in the State of New York, one end of which is in that home ant the other end is now in this building bearing tho manle of my native State.

"I hare been acquainted or have knowll many of the dis- 
tinguished men of the State of Vew York, including such men as William H. Seward, William T. Marey, Ceneral Van Buren, Horatio Sermoul and many oiluers I might name. New York has had four citizens in the oflice of President of the linited sitates. and I have had the lonor of a personal acquaintance with all of them.

" Yew Jork is justly entitled to be called the limpine state. Empirical in its territory, enpupical in its population, cun. pirical in its weath, it is the most powereful state in the Union, and such is its jower that if lats romo to be almost a settled fact that in a presidential election. as gros the sitate of New York, so goes the Union. Jew York has no partirular interest in this Exposition: certainly it mill not adl to he population, and rery little if anything to her trade and commeree. but nevertheless sle has made in a broad and liberal spirit an appropriation for this Exposition, and this beantiful huilding is evidence of that liberality on her part, and she has heren ropre. sented here by the presence of her commissioners and has other. wise eviuced a deep intemest in the sumess of this lixpmilion.

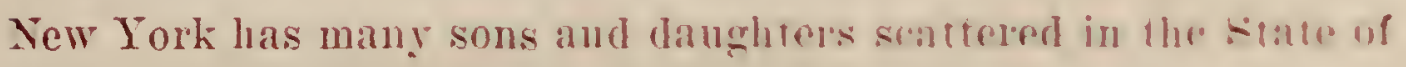
Oregon, and their humble attacliment to the laud in which they were born and the land in which they live brings about a state of union and fraternal feeling between these two different stales. and it is a union of hearts as well as of hands. Portland and this Exposition feel highty honored hy the presence her of these distinguished gentlemen this erening. and I hope they will find their visit here not only a pleasant but a frotitable one, and that they will find in this comntry such inducements that many of them, after they return home. will find it advisable to comse back here, live with us, and he our eitizens. Wfe want men 
from the State of New York and all the other portions of the East to come to Oregon and be a part of our population and help us to build up and promote the interests of this State.

"Te welcome you, and rahe the honor of your presence."

'The program for New York State Day was as follows:

Formal exercises of the day at eleven o'clock in the State building. Dr. Sanuel B. Ward presiding.

Music

Inrocation: Rer. J. E. H. Simpson

Address of greeting; Governor George E. Chamberlain, of Oregon

Response; Lieutenant-Governor M. Linn Bruce, of New York Address of greeting on bohalf of the Exposition Company; Hon. Henry W. Goode, President

Response: Hon. S. Fred Nixon. Speaker of the New York State Assembly

Evening; nine to eleven o'clock; reception and ball given by the New York State Commission in honor of Lientenant-Governor and Mrs. M. Linn Bruce

The distance from home prechnted the possibility of the presence of a larger delegation of representative citizens of the State of New York or of any of the State militia, which quite generally marked the observance of the days allotted to states located near the scene of the Exposition. The weather was most propitious, the sun shone bright, and the atmosphere was most invigorating. The exercises at the State building were attended by LieutenantGovernor and Mrs. Bruce and his immediate party, the legislative delegation, members of the State Commission, a number of representatives of the Exposition Company, commissioners of the various states, and a large number of Portland's representative 
citizens. The Idministration hamd mule signop horitploin was in attendance and gave a hoof concert bofore the ofmening of the exeroises.

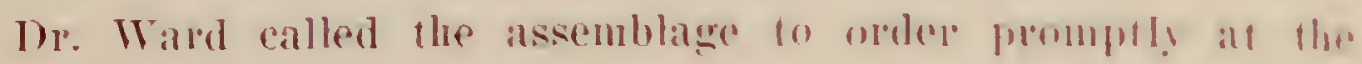

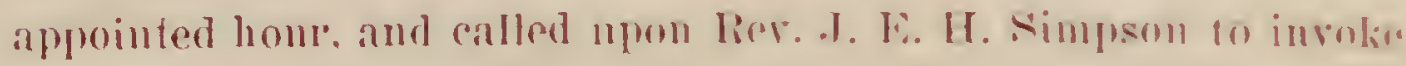
the divine hessing.

Res. I1\%. Simmsonn :

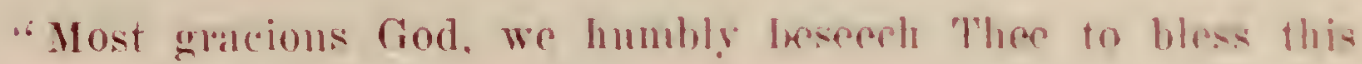
assemblage, bless and prosper all their molelatings io the atdvancement of Thy glowy. We would ask that. Thy hlessing rost mpon the President of the Cuited States, the (ioveruol of Sow Fork and the Governor of Oregon, their oltirels amb thuse in

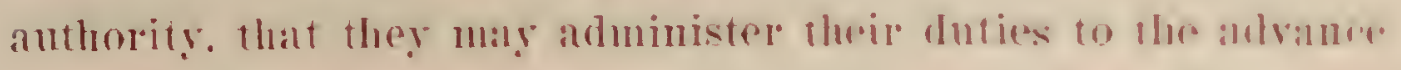
inent of Thy eplory, the good of Thy church. the safery honulo

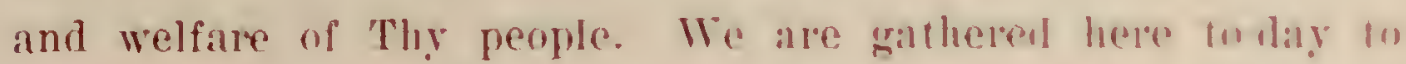
celebrate the barticipation of the great Fupire state in this Exposition. and we besech Thee to honol and bless those repre

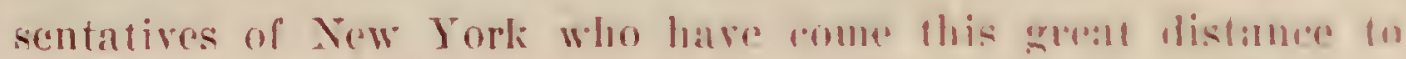

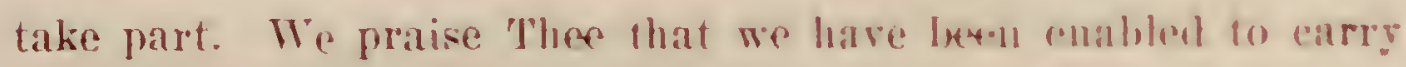
this Exposition to such a greal smeress. Cinide and dired us through life to the end that Thy Inoly name nay Iw Elorified. and by Thy merey we may ohtain everlasting hrssiug. Imen."

1) Ward then delivered Hor following adrloss:

"In opening the excreises of the morning, I har bonen askent to say a few words on Irehalf of the Virw lork siate fommission. We have all felt amply rewalled he the (obdial moreflion hy the

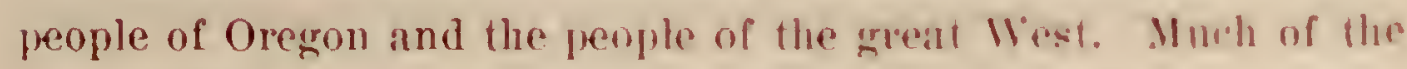

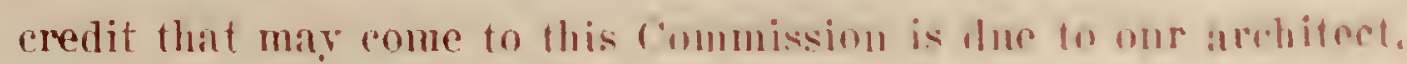




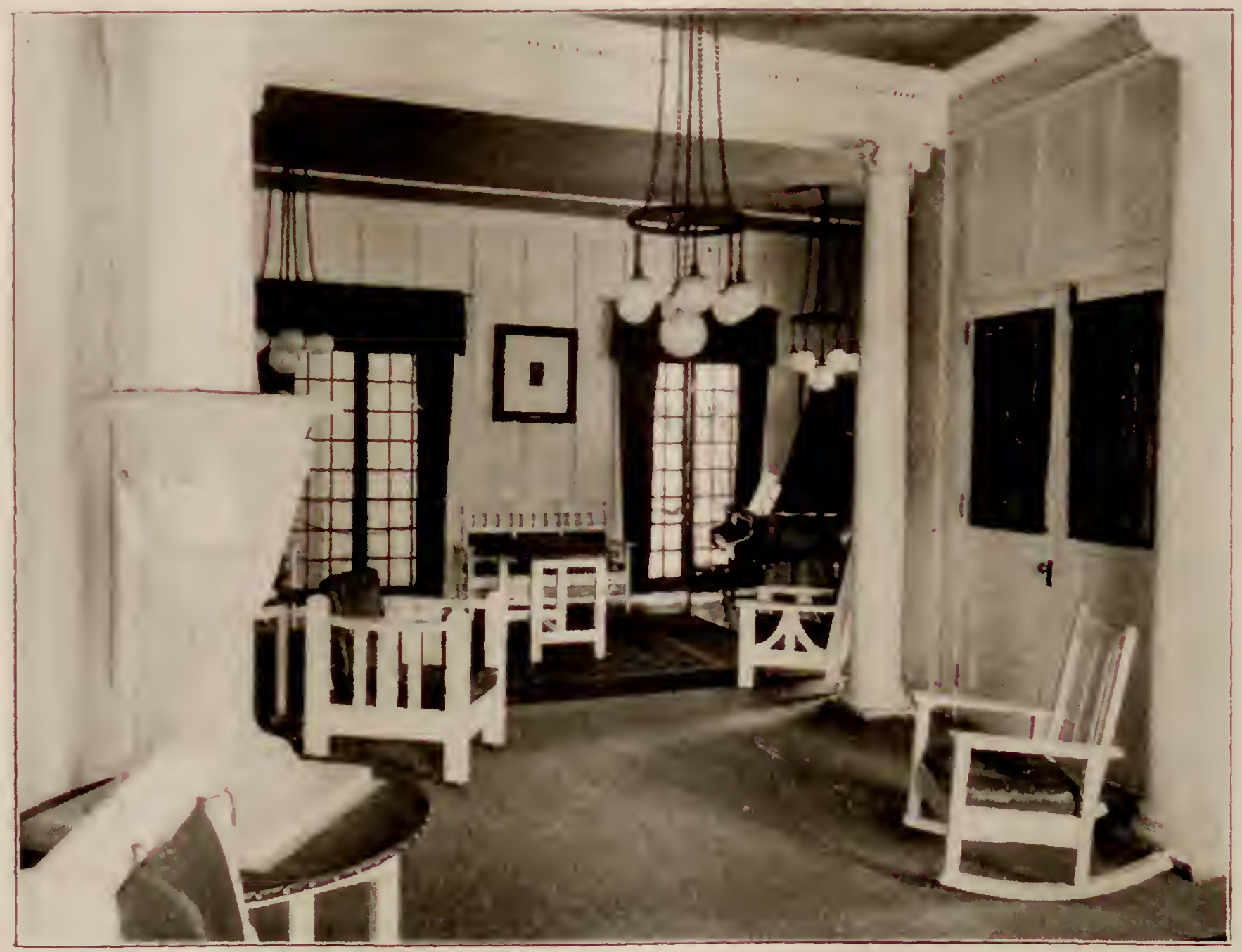

NEW YORK STATE BUHAING, RECEPTION ROON 


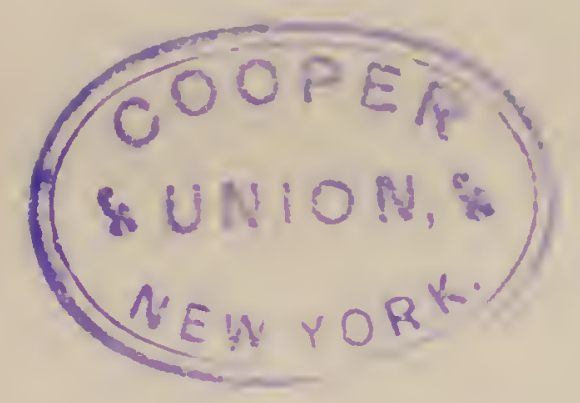


Mr. Clarence Lnce, who las given us this beatiful building at reasonable cost, and who at the opening and during the few days following did more to organize the work of our Commission than all the rest, and we all foel that we can not saly too munch in praise of his efforts and we all feel that they lave been very suc. cessful.

"I have been asked a number of times how it was that New York State was willing to cone this great distance to participate in this Exposition. You all know it is about half way to the western limits of the United States, for Porthand. Oregon, is just a trifle nearer to Portland. Maine, than it is to the western boundary of this comntry. And I have been asked why it was that New York was willing to spend this money to come to an exposition snch a great distance from lome. We have no authority to speak for the Executive, who will be much better spoken for, nor the legislative branch of the government, but as a plain, homble citizen of the State of New York, I may jerhaps say that our point of riew is that New York has two reasons in particular for taking part in this Exposition. In the first place, when Oregon comes to New York and says that we feel an exposition in Portland wonld help the State of Oregon and would lelp the whole Northrest, New York says, fiod bless yon, what can we do to help your cause? While New York may not expect to get any great pecuniary reward from taking part in this Exposition, yet on the other hand New York is fully alive to the fact that whatever helps the state of Oregon, whatever helps the great Northwest, lielps the whole country. We are always williug to give anything we can to advauce the common welfare. I suppose if New lork state is esteemed for anything in the nation, it is for its appreciation of the value of education, for 
its educational instimtions, for its public schools, its high schools, its normal schools and State Normal College. I think it will be admitted by all that it ranks first in the Union in education. Now, education does not consist of what a college boy may loin'n from text books alone. That is really the smallest part of it. What he gets from the books helps him very little in the struggle with the world. Getting into contact with other men- his college professors, the upperelassmen. rubbing against uthers-those are the things which prepare him to batlle successfully with the great problems of life. That is the kind of thing Hant helps a man to become a leadel of men. lindting about a gegser is nothing compared to seeing one; reading about the Rockies is nothing compared to traveling through them and reading about Alaska is nothing compared to seeingr lhat womberful commos. We all understand that the elneation of the man deremese quire as much upon travel and coming into coutace with oflere men. and this is another reason why Yew York is willing lo takn part in this Exposition. becanse it offers the penplo of row liort an

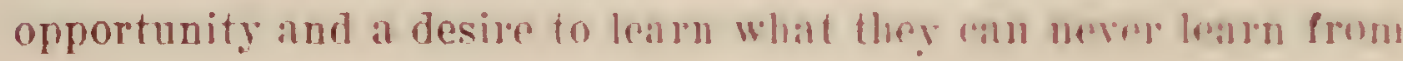
books.

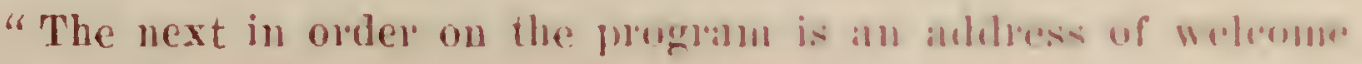
by Hon. George E. Chamberlain. Ciorernor of Orrgun."

Governor C'lamberlain addresserl the ascomblase as follows:

"Mr. President. Ladies and Gentruncul- On ludalf of the people of this commonwentht, I cxtent to all of ?um a must cordial greeting. I can mot expmess (1) ? the people of Oregon appreciate the kindly inreres and intlu ence which New York and her representatives hare expred an this Exposition. Not ouly have they exerten a magnitiont and 
powerfol influence with the jeople? of the great list, but they have stimulated om own people to more emergetic efforts and to a meater inferest in an exposilion roncelyed in the first instance for the development of the West, but in general for the development of the whole comntry; heranse what helps the West, helps Yow York and helps all other states in the Union as well.

"The Ten Fork Commission las been most generous in its courtesies to the people of Oregon and to the Exposition management. All of them-botl the gentlemen, and the ladies of the Commission who have honored us with their presence-have fone all in thoir power to assist in making this Exposition suc(essfill.

-I heard a distinguished genteman sigy the other day that the grople of lew York were not arollininter with the West. I miglut have silil there was one notable exception in the person of the I'proident of the United States. He said lie was surprised to find somuch of refincment, so much rulfure in the West, and that the people of New Tork would be equally as surprised as le was himself. I might be permitter to say that if he linew the western people as well as I do. he would not feel any surmise at that condition, for I might hare told him that every part of the Fast and south has sent the lobly piuneer and teacher to this section of the rountry. New lork las contributed from ler large ranks, learchers and exponents of the law, and the other states in the Fast and Sonth have freely contributed from the professons and othel walks of life. and all of them are the best and unst fronouncel type of American civilization, and the hest blond of all of this early civilization flows in the veins of the people of this Pacific coast. Therefore, there ought not to he any surprise that those who are liere represent the best ele- 
ment of the United Stites of Imeritil athd themefure we have cul.

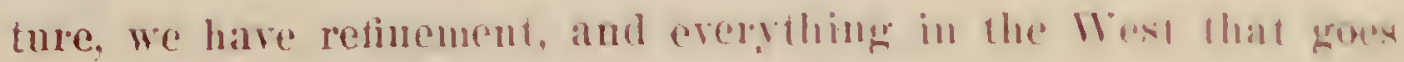
to make up the best citizenship of the Linted stater.

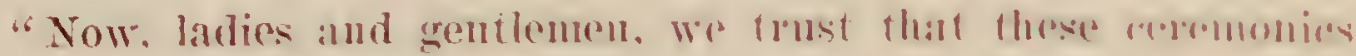

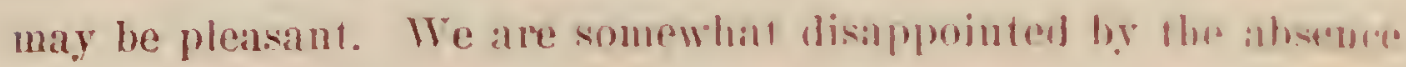

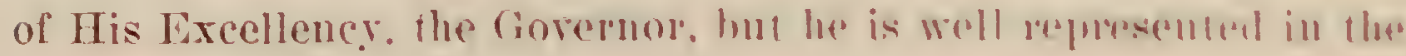

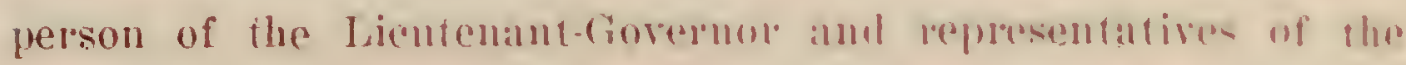

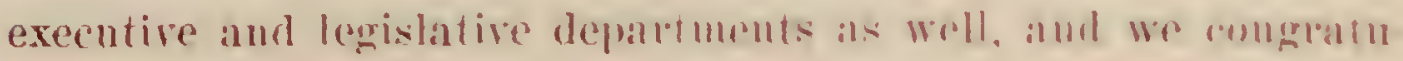
late them and extent io them a most romolial wolromo (1) $10111^{\circ}$ shores. We sincerely trust that yom shạ mily he fllomsant and that when gou return to the bast rou mily he able to give as kindly a word of the Northwest and westeln toust as the leresi

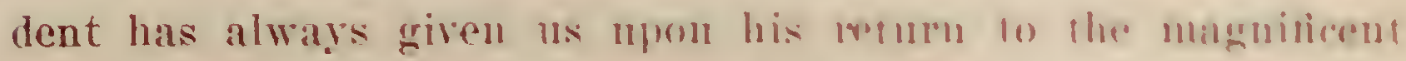
Empire State. We welcome you. and hope that your sta! ma! be most pleasant and profitable as $11 \cdot 011 . "$

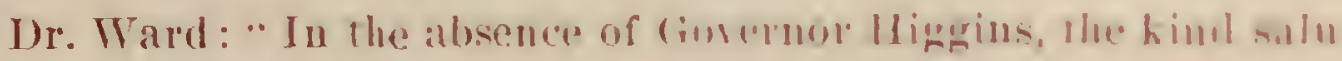

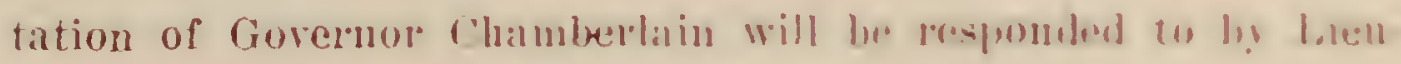
tenant-Governor Bruce."

Lientenant-Governor limee spoke as follows:

"Dr. Ward, Goveruor Chamberlain, I'resident Goudu: I thunk rou, Governor Chamberlain, on behalf of the penple of Sow Yorth for these warm words of weleume, and I luing roul. sil", from the Goveruor and the people of Xow York hearty groptings amb rom.

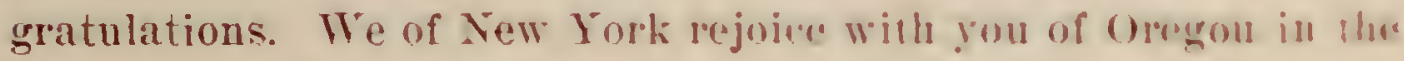

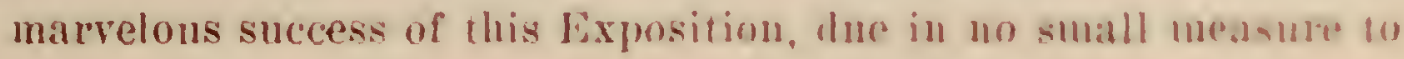
the liberal and progressive policios of your administrofiun and in a very large measure to the energy and enthusiasm of Ho lixph sition Commission under the wise and chicient mammgromelut of President Goode. 
"When this lixposition was first projected it received a hearty response from the people of om State. It seemed to us wise and fitting that the splendid achievement of Captain Tewis and ('aptain Clark shomld be thus rommemorated, an achievement momplpassed in the annals of all that has been accomplished in cxploration mon this or amy other comtiment, and which did more for civilization and more for free institutions than any other similar experlition in the history of mankind. It is indeed well that the rombla of om land and all futme generations should

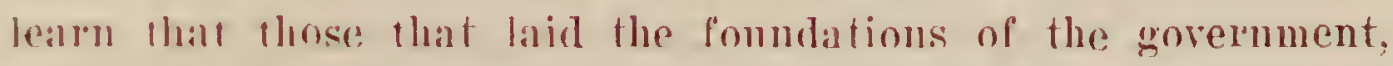
flose who made possible the states ont of which this Union has been instincted, are not forgatien.

"The perple of vew lork thank you for the part which yon have fremitien thom lo have in this Exposition. We are prond of the work of an 'ommission under the administration of President Wark. fund of the prositim which it has been arcorded

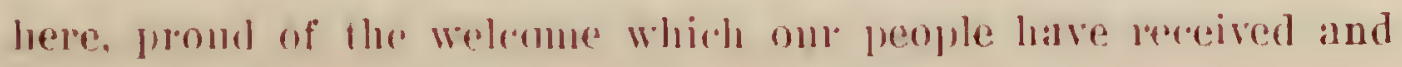
fromd of this lomme which has heen provided by the generosity of the state of Sew York.

"The result of the lewis and clatk expedition romstituted oll. raim which was timally sulstantiated to this great Empire

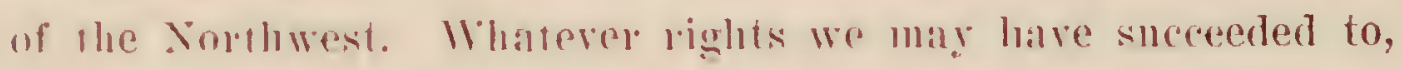
based npun the spanish waim, were vane and risionary, but we had st sllstullial, valid title to this territory by right of discovery and settlement whill resulted from the expedition of Captain lowis and captain clark, and this is the only territory over Whidh that thag tloats that we have alcquired hy such rights.

"But his expedition acomplished something mote. There was not only lle expedition itself. the vigor and the marvelons heroism with which it was ampes on. not only the splendid

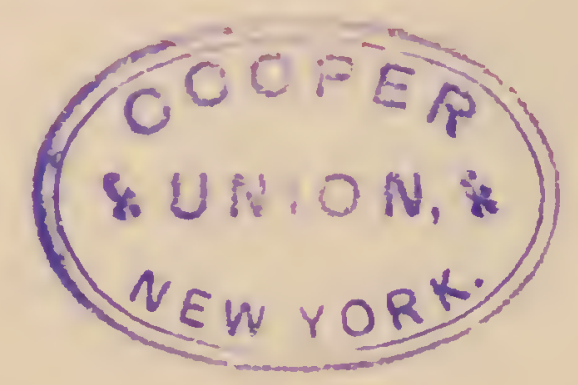


results of discoreling so larger al territory, lont the published records of the expertition infurmed publie opionion and aroused the govermment of the l'mited States to the mutold value and the

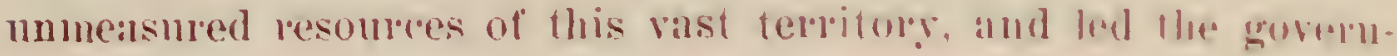
ment and people to insist mpon om clatms founded mon this achievement. which resulted in extending the limits of the Nation until they touched the Parcific.

"And. my friends. this Exposition serves a similat purpose,

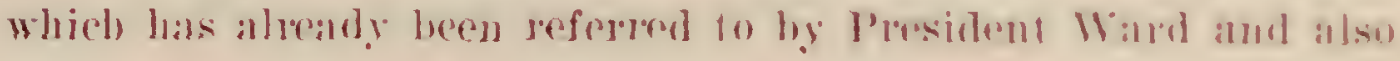
by Governor Chamberlan. It commenotates not only what

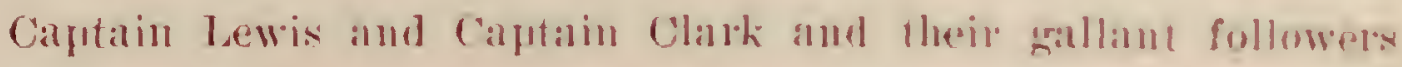
did, but it commenomates atso all that came after them - this miracle of development. the wonder of history. these greal amd powerful states which have been built hrow and which are inderen the strong right arm of the Republic. It is in rommemoration of all this that this grand Exposition is hedel. What the work of Lewis and clatk did for the peoplle of that lime this lixposi.

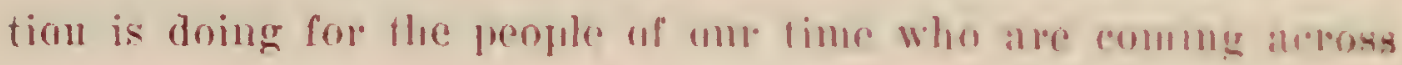

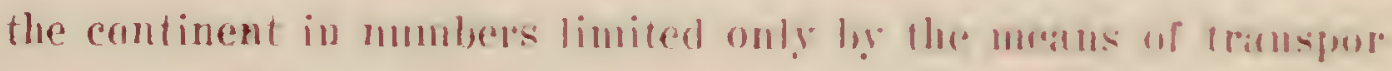
tation, viewing this grand comntry and thus arduliting some adequate conception of the immensity of the linifed statro. Bacou said that 'travel maketh a loroal man." and lee who has

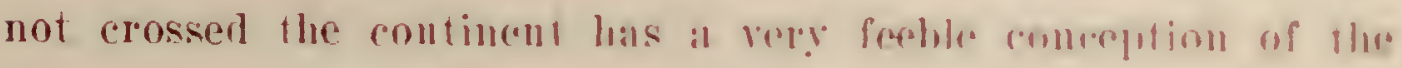
possibilities of this commly of our.

"The fact which implesses one mpon smelo a jommey more than any other is the similatrity of omr people: Wherevere wre see them, whether in Massachusetts or in Oregon, in Now lorti or in Ciali. fornia, in Wyoming or in Maime, Hey are the salne people, with common purposes, common interests, common idrals. rommon

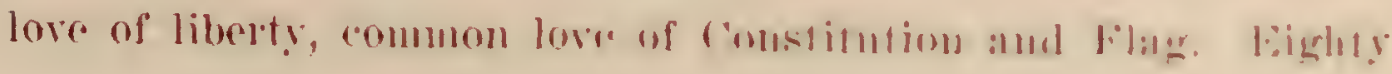


millions of freemen with a like purpose, sympatly. emotion and ambition.

"On this anniversary occasion our minds go back to those who lie sleeping on the plains, to those who rest on the hillsides, the grand men who bore the heat and burden of those early days, the men who laid the fomndations, builded these states and handed them down to us to enjoy and preserve. Yes, these grand institutions are ours to enjoy and ours to preserve and ours to transmit unimpaired to the generations following.

"I see gathered here many who first saw the light in the State of New York. We are proud of New York, but we would not boast. We are prond thit the people of New York spend fortyone millioms of dollars ammally upon coluration, endeavoring to lear, as you are here, sons and daughters who shall come after us worthy to maintain these dearly bought liberties. And to you from New York who left the old state years ago, let me say that the sun is just as bright, the fields are just as fair, the streams are just as elear, the people are just as generous, hearty and progressive as when you left the old home, and when you go back to the old homestead you will find, perliaps not the old friends, but the same warm, generons people whom you left rears ago. We alle prond of the frat rou have played in the conquest of the continent, and in what fou have done here on the shores of the Pacific. There is not a state in the Union in whose development some son of New York has not played a noble and unselfish part. We are proud of you and we are glad to welcome rou here to-dis.

"These ceremonies are to be brief, but you will permit me to sily that in rery truth there is no East and no West, no North and no soutl, only one common, mited country. No matter in what 
state we live we are Americans all. There ale questions which seem to be sectional. Jom have hesu romsidering the question of irrigation. The people of Sew lork are just as much infrepested in the question of irrigation as those who dwell ou the great platus between the Rockios and Cascanles. Wre are awille of the impontance and benefit of maling these leserts blossom like the rose and grow like the farden of Eden. It is cromanly a beneficent govermuent that takes the waters fom these momm. tains and blesses the thirsty soil, camsing it ' (o hring fortl and bud that it may give soed to the somer and bread to the eater."

"New York with its immense weallh and pupulation brallo a lasge percentage of the cost and expenso of the Nitional grovern.

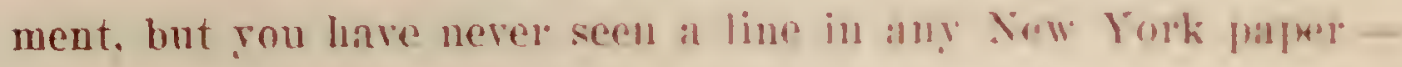
you have never heard a word from lew lonk lhat was un in favor of a erenerous policy for thr developmens of the Wese It is by no menus a local question. We of the kast an inferesforl because whatever helps one sertion of the count? helpo all. One.

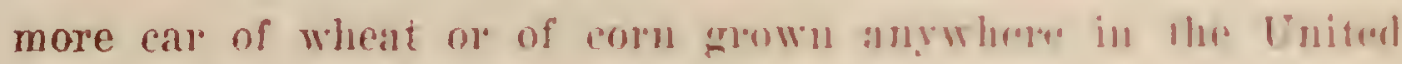
States benefits Yew lonk as woll as corely olled lial of the country.

"You have been considering questions of Isiativ imuigrafion. New York is the centre of commerere. and enmmerere defrends not only upon ships and harvests and factories lout upoul markets. And the greatest unexploited market of the world is the Orient. New York stands for the wise policy of hel favolite son. Throllore Roosevelt. for the integrity of the chinese limpire and for the open door. for an equal rhance fol rever mation and erely man in that gieat and wonderful market. It is 1101 a lowal qureation, but a national question to be settled upon phe broud lines of a comprehensive national policy. And we of New lork are just 


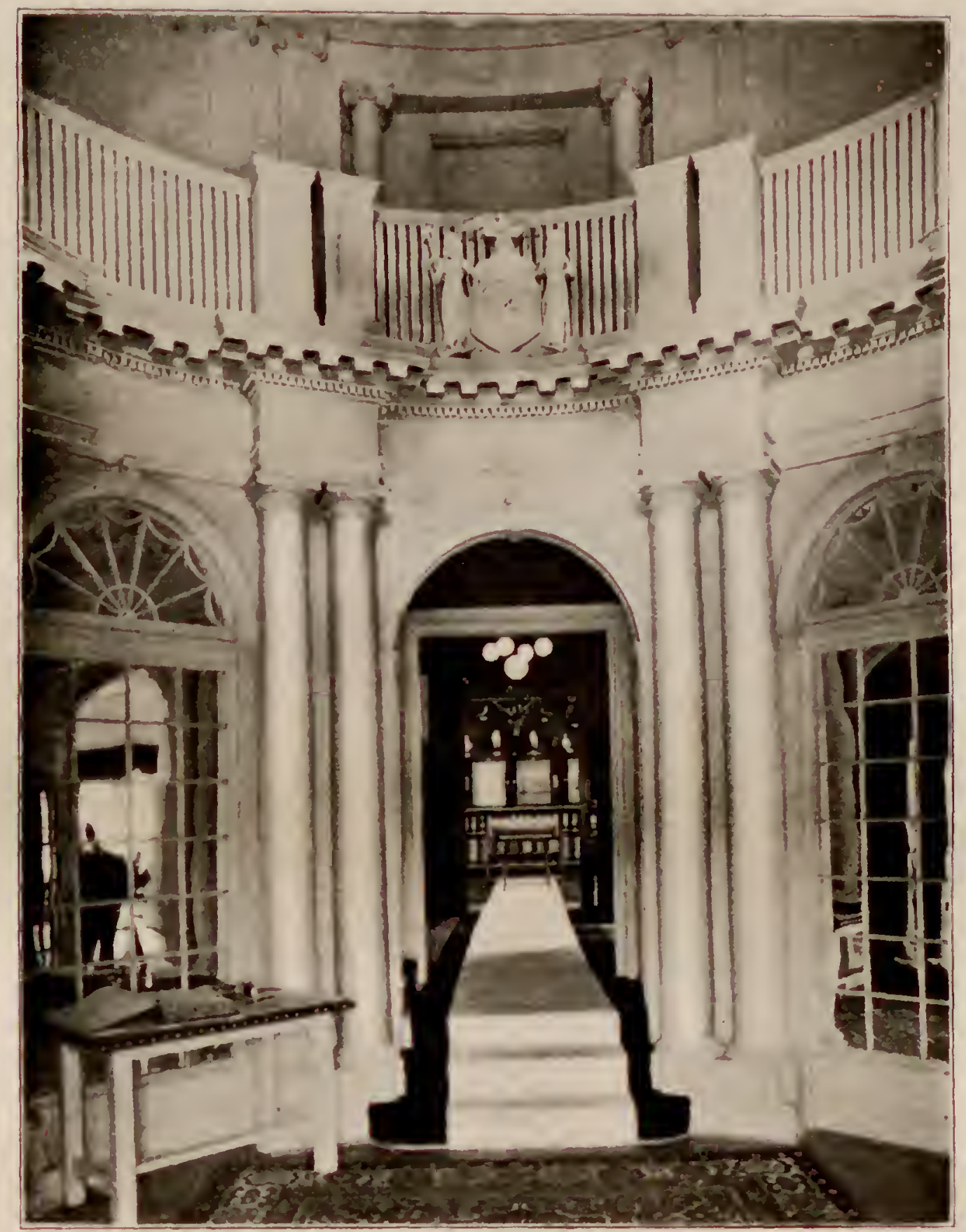

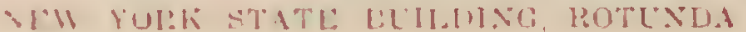




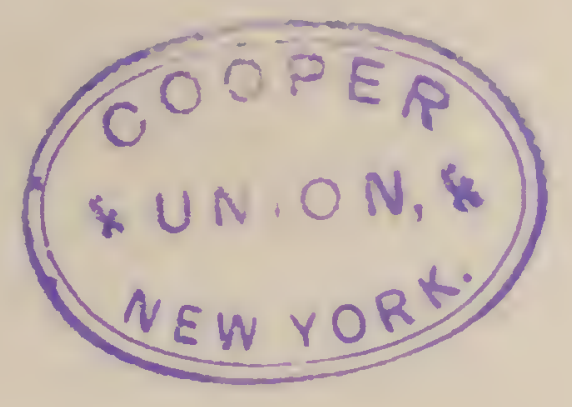


as intensely ahive and deeply interested in this question as you of the Pacific slope.

"You have no small Americans in the West; there may perlaps be some in the East. but if they would only make one trip acloss the romntry they womld rertainly become sreater Americans.

"In the provitence of God we hive recently been ralled to assume obligations which we had not foreseen nor anticipated. We have been ealled by Him to take a seat in the comucil cluamber of the powers of the world. We have taken that seat and we intend to keep it. We have taken onr place als one of the first powers of the eath ly leiglit of achievement, and we will not shrink from any of its responsibilities. We desire through the instrumentalities of peace to promote the lighest good of mankind. Me slatl insist mpon a diplomacy which means hetween uations the sume openmindedness and the same fail play llat should exist betwern man and man.

"I an an optimist of optimists. I believe that we lave here on this continent the inleatrest tye of citizenship that the world has ever seen. I belicre that a rentury hence-mpon the two loundredth anniversity of the lewis and Clark expeditionyou will find in these luited states over fwo hundred millions of people. 'They will not differ from the people who are liere to-day. There will be the same tlag, samb constitution, same love of liberty. I beliese God in His l'bovidence lats still greatre things in store for these United States, and I praly that we may be used of Him to bring in all the nations of the world the blessings of peace, of justice and of liberty.

"On belalf of His Excellency, the Governol of the state of New lork. I tlank rou for your presence here to-day." 
A selection was then played by the ordestra, aftor which Hon. H. IT. Goode, President of llor lixposition, was introduced by Dr. Ward. and said:

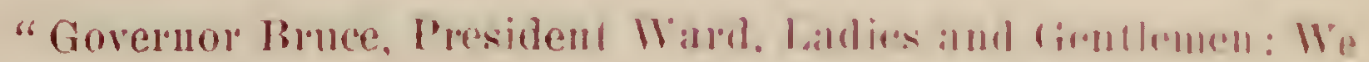
have been looking forward to New lork Dill and the presence of the representatives of the State of Xew Iork. It threfore gives me great pleasure to say a word of greeting on Nell lork biy. I doubt, howerer, if I shall be ahlo lo andequalely express the exact feelings which the management of this Exposition dhopish toward the state of New Fork, its (sovermol and its Stane l'mu

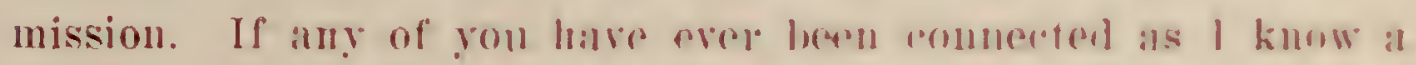
few of you at least have with a world's fair or a national expu sition, you will appreciate what it means to les fatled mpou the back in the early stages of the projert. The word has gune forth that you are going to hold a national exposition. lou must produce results. You must certainly persuade the states of thr. nation to participate. Now, I eonfess it was witl sonue mis givings that we sent a commissioner to the state of New York, although we knew that New York had been represunfed at every national exposition that has been held in the linited states. Yet we were loldiug ours right after the langest fair that the world has ever seen. The State of New Fork in connection with the other eastern states had sfrent rery large amounts of money at that Exposition, and we felt that it might he dinicult to nathe

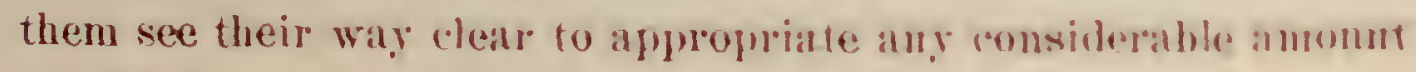
for us. Much to our surprise and gratification, howerel, onr 1.0m. missioner was received with open arms. It look no work whiterer. The State of New York said, "Why, certainly we will come, we will be glad to do it,' and iumediately made a liberal appropriation and promised a further appropriation later. Which has simcolown made. 
"We understand and thoroughly appreciate that New York has nothing to gain directly by its participation at this Exposition. Son have come leve merely to show good will and your sincere desile to help the best interests of the Pacific Northwest. New York lias no agricultural or horticultural or timber products to show in eompetition with the exhibits at this fair from the states of the West. bnt she has made a very attractive exhibit of odncational allairs in the State of New York. She has erected a rerg beantiful building, and has matedeally turned it over to the kxposition management.

"Ml. Luce, who came to us first, said. "We want you to use the New York building whenever you desire." And whenever we have wished in hold a function the huilding has been practically relosed to the public so that we might be free to use it as we saw fit. The pxhibits have also been elosed. I am afraid we have taken al times foo much advantage of that generosity, but I can only sily this, that in addition fo its liberal participation at the fail the state of New York has saved the Exposition manage ment a verg large anount of money he its kindness. Now, we have an additional honor to-day in the presence of the LieutenantGovernor of the State and a mumber of legislators of New York. They have come here esprecially for the purpose of celebrating this di!y and doing homor to the State of New York at this lixposition. It gives me the greatest pleasure to again extend them al most cordial welcone.

"In conclnsion, Governor Inrure, I wish to compliment and congratulate you upon the work that your commission has done at this Exposition. They have made themselves very dear to the hearts of the Exposition managenent, to the State of Oregon and the people of the entire rorthwest. I thank you." 
Dr. Ward. in introducing Speatim Nixon, sald:

"Last. but by no means lenst. we are to heal from the distin. gruished Speater of the Askembly of the stan of sew lonkt a man who has held that position longer than an! oflep preson ever did. and has kept it hecanse he deserveal it. l'omal we to introduce the Honomales. Fred Xixom. Spater of the Issembly of the State of New York."

Mr. Nixol spote as follows:

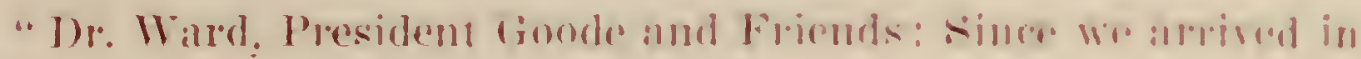
Portland, which was only fiftorn of righteren homp agu, mublic opinion has demonstrated to us that there is mue mall more prominent than aus other in conmertion with this lixpmeitum

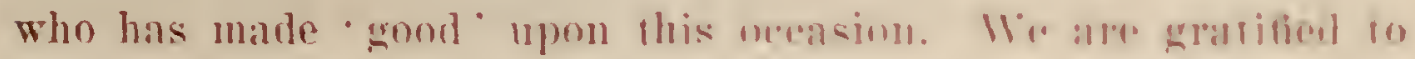

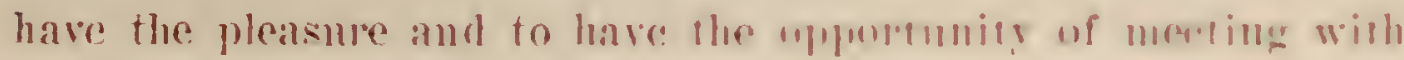
our friends of the great West upmen an measion lite this.

"Before it passes from my mind 1 want to sxpreses the spupe ciation of the legristative delegattion here from the fompire siale of the work which has been sn well dome hil hor sow lonk state Commission. It is for ns to stand hesweren the propple and thes

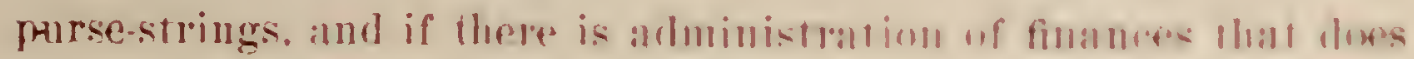

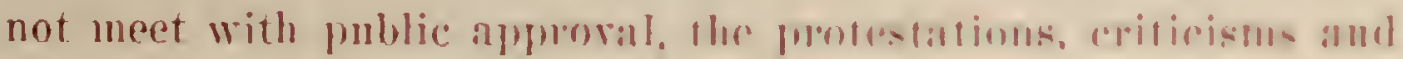
demands for explanations come: npon there whe alo in somb with the State treasury. Bat I wish to say it has never leren my

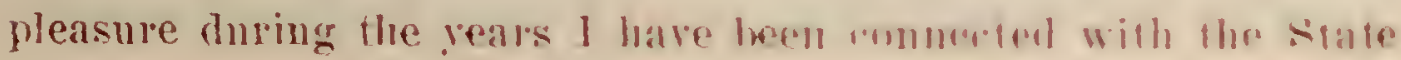

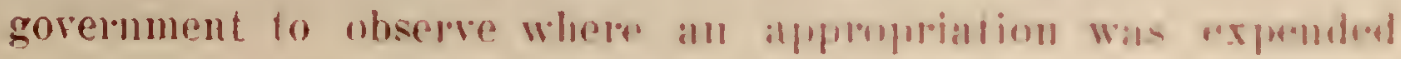

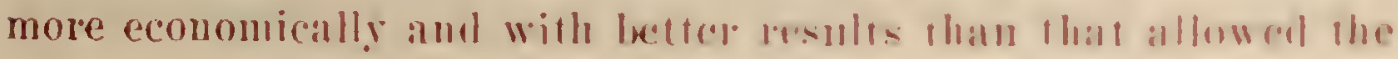
New York State Commission, as hown in the holdriug of this

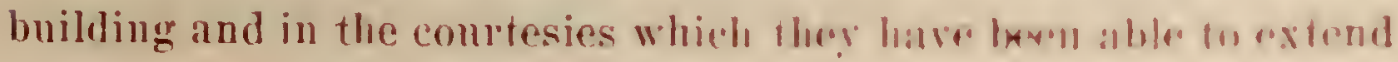
to their friends in thr greall West. 
"I wish to say, President Goode, when your representative came to New York he found us in the same spirit in which we have always been towards expositions of this kind. New York is an edicadional State, and we are glad to bring lere, if nothing else. mur exhibit of that work which in the history of the Empire State has made wreatol inpress than anything else that the Sulpile slate has erer done. We are proud of the elucational system of our State, and whichever party has been in power, the ome baly or the othel has always endeavoled to maintain the standard that we think - or perhaps are conceited enough to think - is the highest standard in the United States. and that means in the whole world. Wa gave to this commonwealth and to all the commonwenths which romprise this mited comntry their common school systems. It is the common school system which has been spread thronghout the civilized world.

"There is all obligation upon the part of New York to make grod mpon occasions like this. We appreciate the prestige of what Vew York does and her influence upon her sister states. We appleceiate the fact that the people of all these commonwealths look upon New Yolk as the great financial centre of this country, as she is, amb while the demands made upon her are in proportion to her ability 10 mest them, at the same time you will always find the siate of Yew York ready to do her duty as she sees it.

"An opportmity is given to many to become nore familiar with the extent of the United states. Of the party who came hele fromt the Legrislatule, none of us lat ever before crossed lhe liockies. nome of us had evel before appleciated the distances and cxtent of this western comntiy. Our idea of going from here (1) San Fiancisen was similar to that of the foreigner who came to boston and wote bich to his friends that he would stay in 
Boston oret night. gen to the fatr alt lhivago in the morning and return to Boston at night. We hal an idea when we rame here that we would take a little onting and run down to San Francison in three or four homrs, but we find our geograply incorrect. It did not oceme to us that the coast line extending from Maine do Forida is the coast line of hut three states mon the Parific slope.

"I anl glatitied. and I kinow that I express the sentiments of the gentlemen of the Lecristatme who have accompanied me upon this trip. that we have bers arended the privilege of meeting

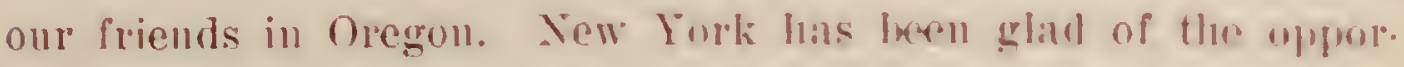
tunity of serving rou and abling in this fixposifion, and in so doing possibly we have not acted from an unselfish standpoint. New York appreciates the fart that her snus and daughters are to be fomb in all of the states of the great Northwest. Whe

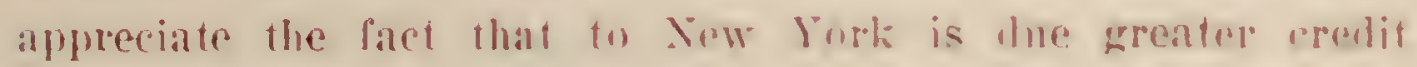
possibly than that whide is due to the fwo groftromen who were sent here by President detrelson, and from whom this Exposi.

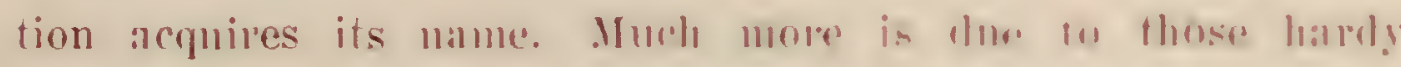
pioneers, those missiomaries who elusem the Rockies hatch, I helieve, in the 30 's and sowed the seed of civilization npon the Pacific coast. They "ame herpantuated hy a desire en droblop and settle this locality. They anme here withont rexpectation of reward. and they weres lice ones. I heliere. who made it possible for this dominion to be obtained without conquest: they were the ones, I believe, who sent to Washington their represontatives and pictmed to the anministration, which at that time was not especially friendly to the development of the Northwest, what a great country this was, what its possibilites were, its wealth in mineral and timber. and it was due to their cofforts that the 
United States a few years later obtained control of this territory within the confines of which many states now exist. It seems to me more aredit is lue to them than is given them. Those missionaries came Prom the Empire State. New York is sending ont missionaries crery day. We want to keep the same position from an edncational and from a Christianizing standpoint that we have kept in rears gone hy. New York yon will always find is willing to push the development of civilization. New York as a State stands with her sons and with her danghters with an open poekethook to advance those things which make for the elevation of mankind in general.

"It has been is pleasure to us, President Goode, to contribute in onr small way to the suceess of this Exposition, and I want to say to 011 frims $^{\circ}$ of the West and Northwest, no matter what the time may he if you want anything of the Empire State, no matter who is in power, whether my friend Rogers representing one particnlan party, or my frieud Palmer representing another, rou will always find the latelsatring of the Empire State door hanging onl. If there is anything we can do to help build up this conntry which we all love so much, New York State will always be ready to do her share.

"I desire on behalf of the legislative delegation to express our appreciation, President Goode, for the pleasant things you have arranged fol us during oul visit. We will be hele during the next three or fonr days. and I want to say we will carry home impressions of the West snch as never conld be gained except by a trip ovel the Rockies. We can say to onr friends in the East that our sons and daughters who have crossed the conlinent and have fonnd their lomes in these western states are well lowated. and we ram say to those boys who are a little 
yomngel than we are and whese ifleas are not so firmly hound as ours are that if they desire to rentme anal from the home State and inquire where there is wreat opportunit! in husiness or profession, to follow the example of tewis and clark and cross the Rockies and come to this heantiful conntry of yours.

"I desire to express my must rordial appreciation for the comp. tesies which have heen exteuded to 11 , and I want to sily to yon that. while this delegation may uof be as demonstrative as some others, they are none the less anpreciative."

At the conchnsion of the sueaker's address the band mayed the national anthem. the andirners standing. This entarl thro formal exercises of the day.

Immediately afterward Lientenantelomenor Brue held an informal reception, pleasantly greeting soreral hundred peoplo who pressed forward to grasp his hand. It the conchusion of the reception the entire oflicial pilly wis photographed upon the steps of the state building. Lunchenu was servel nunn the verandas of the bnilding and the afteronon was devored fo sight seeing, the Lientenant-Governor's farty visiting the forvernment building. where they were met by Mr. Gedlles. thr oflorial in charge. who explained the exhibits to them.

At nine o'clock in the erening was leed the reception and ball in honor of Lientenant-Governor and Mrs. Brucr. Both the State building and the pavilion annex were used for this pur. pose. Two thonsand invitations had teen issued for the function. those invited induding the President of the Initerl stathes. his Cabinet. members of the Tinited states Supremre comp. oftiers of the United States amy and nary. the Voll lonk sinte mem. bers of Congress, State oflicials and the memhers of the legislat ture of the State of New York. Supreme Comrt Instices of the 


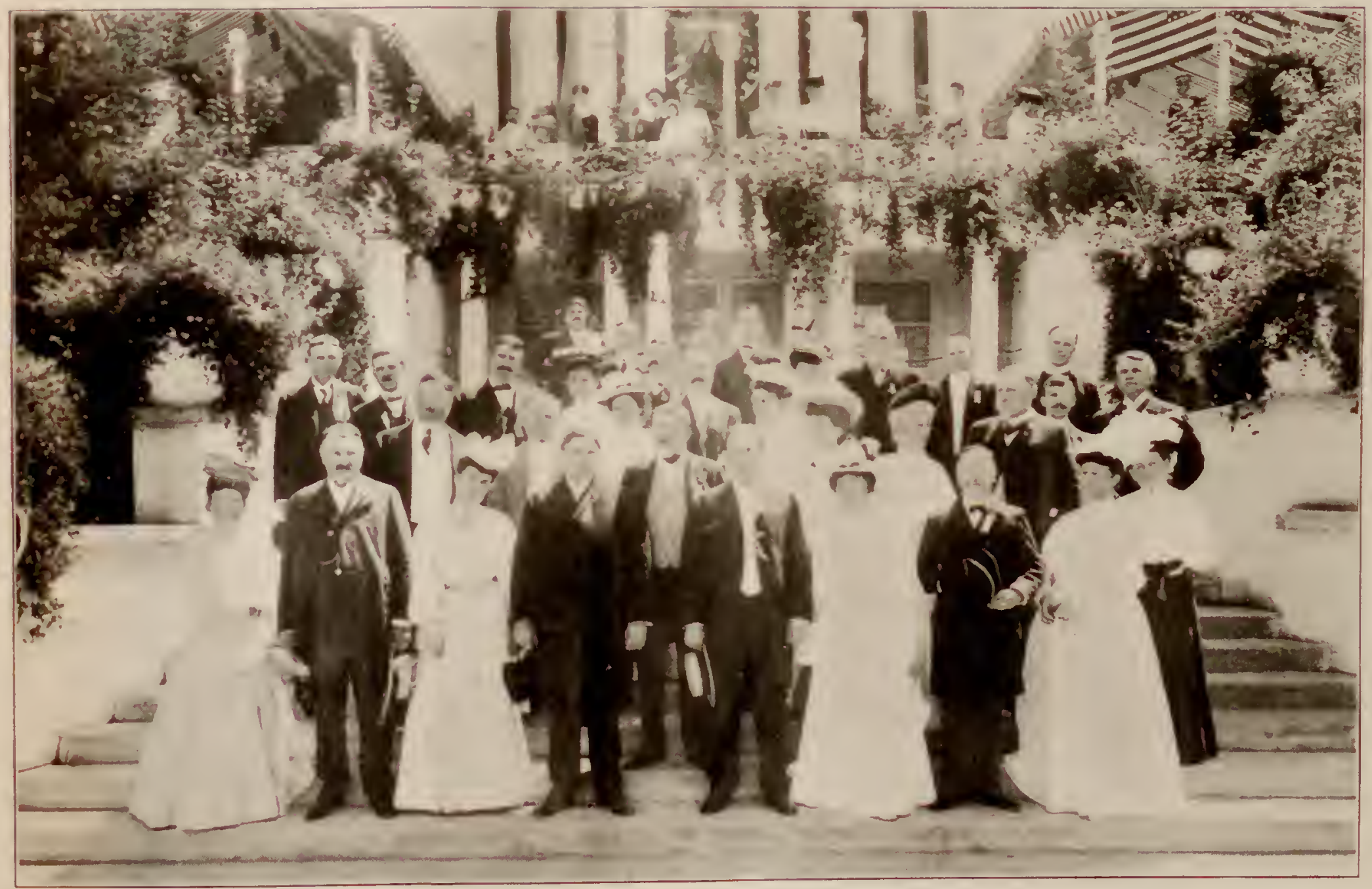




\section{COOPEP \& UNION, \& NEW YORK. \\ EW YOR H.}


State of New lork, Exposition officials, commissioners of states represented at the Exposition, several hundred citizens of Portland and many prominent New Yorkers.

The function was the most elaborate and thoronglily enjoyalele of any hold during the entire Exposition period, and thromehont the evening the building was thronged with those who assembled to accept the hospitality of the Empire State. The pavilion annex had been comverted into a perfect bower of green by the bepart. ment of Works of the lixposition, the mprights and heams being completely hidden by masses of foliage. A profusion of American flags lent rolor to the serene and humdreds of electrite hulbs encased in diphanese lanterus furnished is subdued light which was most effective. Parson's orchestra of 17 pieces wats in altendance and furnished musir for dancing throughom the crening.

The gnests were received in hehalf of the Commission by r'ommissioner Charles R. Huntley, who presented each guest to the Ifientenant-Governor and Mrs. Bruce. Others in the receiving

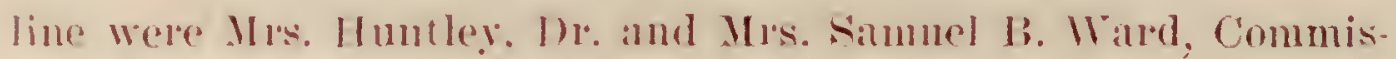
sioner Hemp Alman and Mrs. le Lancer M. Ellis. The guests were presented to the receiving party by the Commission's executive oflicer. Mr. DeLancey M. Ellis. A squat from the Tenth Cuited states lufantry acted as gruad of honor. A buffet supper Wras served thronghout the rrening, the guests being seated at small tables upon the verimbs. It was long past the appointed hour for the "lose of the reception when the last guest had departed.

On sunduy evening the Commission gave an informal dinner in lonor of the legislative lelegaltion. the guests, about 30 in number, Wring romposed chiefly of the ofticial party. Commis. 
sioner Huntley presided in helanf of the Commission. (1) the following evening. Monday, Angust 21st, the President of the

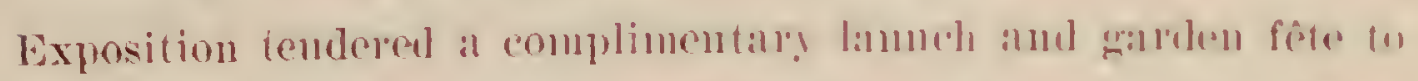
the Lieutenant-(rovernor and Mrs. Bruce and the Sew York delegation. About 300 guests were bilden, who assembled at the New York building al $\&$ o'clock. Linumches were hoarled shortly afterwards and in a procession moved slowly abont the lake. The view of the grounds at night from the lake was nne long to be remembered. and was enchanting to hlose who upon that occasion saw it for the first time. Each lanmell was gaily decorated with Japanese lanterns and evergreens. Inring the ride a concert was given by the Hawaiian hant. assisted ly. Monsieur and Madame Begue, soloists of note. Who were at that time filling an engagement at the lixposition. and who were accompanied by the Exposition orchestra. Wt the andolnsion of the boat ride the entire frarty adjournel to the grose in Centemnial park, where tables liad heen spreatul :mmong the tross. During the serving of an appetizing supper a rauleville fur formance was given, greatly to the cujoyment of llwe gursis present. Japanese jugglers. the Hawaiian hand amul Thalian soloists kept the guests delightfully antertained until the woe sma' hour's.

This was the final function in connection with the Sell York State Day festivities, which had been most successful in every way, and which were marked throughout by the displat! of : mon-t cordial spirit and feeling of gond fellowship wn the part of bxpo sition oflicials and the State oflicials of (1)regom. It is mmoces sary to say that the feeling was heartily renifureated by the representatives of the limpire state. 


\section{CHAP'TER VII}

\section{Reception to New York State Society of Oregon}





\section{RECEPTION TO NEW YORK STATE SOCIE'TY OF OREGON}

( N Friday evening, Inly Tth. the New York State Society of reception and bumch panty. This society is composed of present residents of Oregon who were either horn in the state of New York or had lived there for a period of tive gears consecutively before they setfled in the western conntry. The society meets once each month for the pmpose of social intercourse and keeping alive the affection of its members for their native state. 'There were members present from all wilks of life. Some had but recently moved to the western romntry, while one nember had not seen his native Stand since 1553 and had covered the entire distance to the Oregon country on horseback.

The president of the society is Hon. George H. Williams, former Mayol of Portland, a native of Lebanon, N. Y.

The guests were received in behalf of the Commission by Commissioner and Mls. Hanry 1). Williams, and were assisted hy President Willians of the societr. Soon after arrival a formal welcome was axtended by Commissioner Williams in the following words:

"Mr. President, Ladies and Gentlemen of the New York Society of Oregon: It affords the New York Commission to this Exposifion great pleasure to welcome rou to the State's temporary home on the Pacifio coast. I think there will be 10 gathering beneath this loof that will give so mnch pleasure and satisfaction to hoth guest and host as this. Many of you left home when 
the prairie schooner was the only "slepere which rossed the trackless West, and most of rom. I find, hate heen some years in the land of the horizon, and ret all retain a stromg alfection for the Empire State - and well you may, not only becanst it is the place of your birth, and beranse many pleasant recollec. tions arise as yon tind rontiselves for a moment agrilin on York State gromnd. but besanse of the justly promd position which the State ocempies in the great sisterhood. Thonsands of the sons and daughters of lew Jork have grone forth to shate their chams in the West, and romld the old states spalk I kmom she would roice her pride at their athievenents. Distinguishenl men of many states west of the Mississippi rall lew lork 'home, and your honored President. once a member of P'residunt Cirant's Cabinet, and always a man foremost in the communty in which he lived, is no exception.

"We recognize the West's bommlless arres of growing rom and bending wheat, your vast stretches of graming lands. your mighty pines and your seemingly inexhamstible mines. hul 110 du forget that the hills and vallers of lonk stalte sill richly reward the thrifty hosbandman and that fhe comfort uf his home and environments are most gratifying.

"But the Empire State is here not only" w milke modest exhibit of the products of its lands and farchories, to show its progress in educational matters and in the advanced troatment of its unfortunate and dependent ritizens. hut to pay its respects to the preople of the Pacific slope and to do esperobial homagne to its sister, the State of Oregon. and to her "nrergetiv and pmblic spirited men and women who have male hais heantiful and won. derful Exposition possible and sncessful.

"I was expressly charged hy Governor Higrins w welnomu in 
his name this society, and I take great pleasure in doing so. Many of you have told me of the pride you have in this beantiful building, and that it is more homelike to you than any other building on the grounds. This is most gratifying and I trust you will not fail to use the building freely."

President Williams responded as follows:

"I suppose it devolves upon me to sily something. although I was not aware that speaking would be in order on this occasion. But I want to say that 1 have no doubt, and I presume the members of the New Iork State society here entertain no doubt, that the welcome extended to us by the gentleman who represents the limpire state als a commissioner is a hearty and cordial welcome. And I believe it is characteristic of New York people, when they do extend a welcome to others to make it a rerge sincere and hearty one. And so fall as I am roncerned, and I presume I represent the other members of the society, we reciprocute this feeling, and we are exceelingly pleased and gratified to be here this evening to meet people from the great State of New York. Nithomgh I have been absent from that State many years. and have lived in the West for over sixty rears. still I have a great feeling of attachment for the home of my boghood and for the people there.

"New Vork has a very conspicuous position here, notwithstanding that her exhibits are less extensive than those of some of the western states. Sile has an exhibit of men and women, and New York can hoast as fully and with as much pride as any other State in the United States of the men and women she has produced. Ind I might say I have been acquainted with a great many men from the state of New York, and to-dily New 
York may feel prond that at the head of this nation, a native son of the State of New Tork is administering the afrairs of this great comntry with satisfaction to the preple of the country and to the pride and homor of the American nation. We are to have a Secretary of State who is a rery distinguished son of the State of New York. I have kmown a great many of the wreat men of Yew Yolk. Wut l need not lake time to lefer to them here, but all of her ment who have figmed conspienomsly for the last fifty reas have been know'n to me and I have been known to them, and New York has nu reason to how its hearl to any State in the Cnited States so far as the ment and women of that State are concerned. I think that verw look has male a creditable display here. She has put hereself in il pmitim herer of which she may justly be proud.

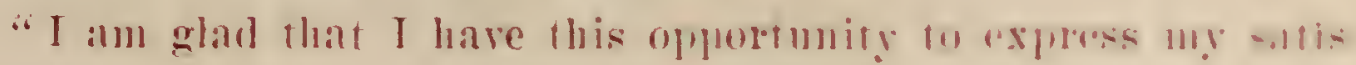
faction at meeting so many people from rew York here this evening, and I hope to have other oppormutios fo meet a large number during the Fair. And I hope that aftel the Commissioner has returned East, many more will rome form the Emplire sitato to this Fair and learn what they mas lean here about this greant

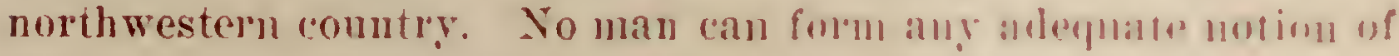
the extent of the United States, of its resomres and its alph. bilities, unless he has traveled across the continent, and has cone from the East to the West. Then he can appreciate the great. ness of our country and its wealth. and he can then realize the justice of our cham that this northwestern country is a great. rich, productive comutug. and above all onr olam that it exrels any other part of the United States in scenery and climate, and we are persuading onrselves that a groat many of the people

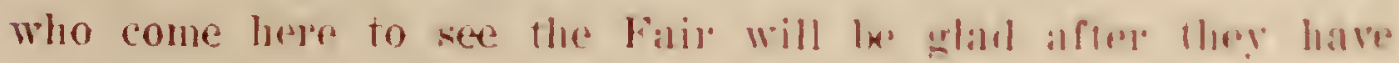




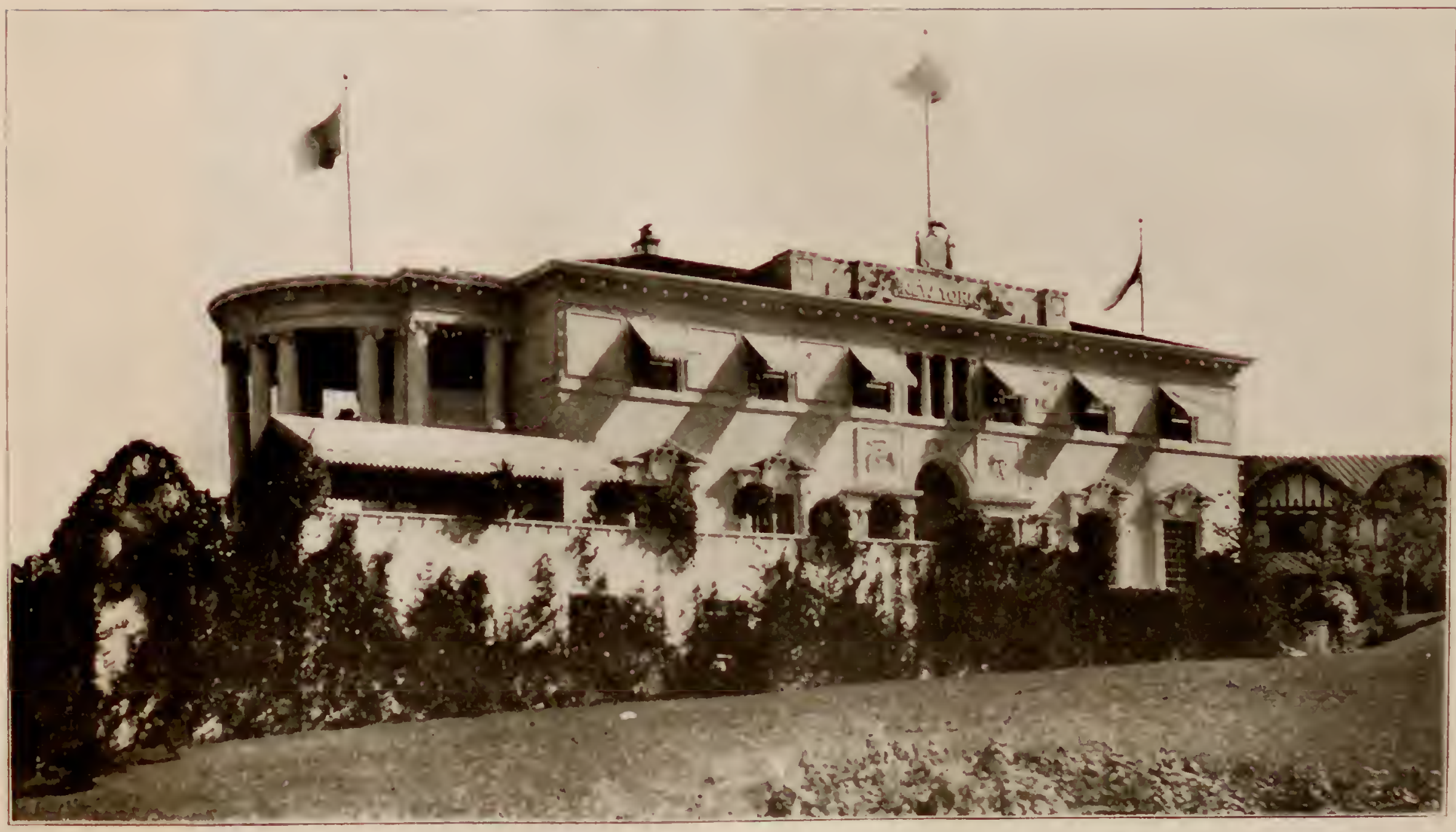




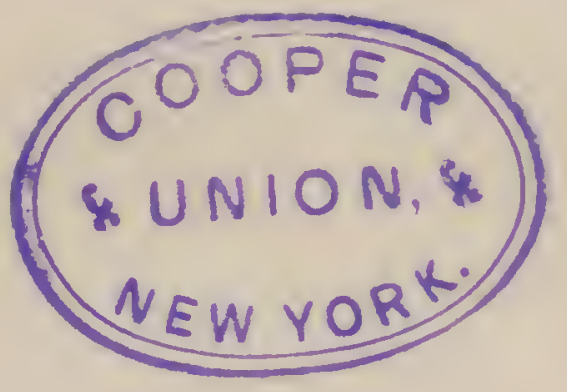


sernt the conntry to come bark and be citizens-jermanent cilizens of the State.

"I hink the people of Oregon may feel prond of this bxposition. I ronsider it highly creditable to those who have been conrerned in making it what it is, and I have no doubt that the ferople of the lonted stalles will be perfortly satisfied with what they see. and that they will feel inclined to give to Oregon and to those who have contributed to this Fair the credit and honor which is due them from the excellence of this Exposition."

. Mfer the address of President Williams, lannches were boarded for a ride about the lake. after which the entire party returned to the State building where light refreshments were served. The ocrision was foled hy all a great sucress, and each guest expressed a pride in the structure which their native State had receled and their appreciation both individually and collectively of the fact that the state had participated in the Exposition. 

CHAP'TER VIII

Financial Report 



\section{FINANCIAI, REPOR'T}

\section{EXPENITTURES}

The Eureka Co., contract on building......... $\$ 10,82000$

The Eureka Co., for extras on building........ 2,86796

. Tolm Barrett Co., electrolier's special design and fixtmes throughont the building............ $808 \quad 03$

Lipp \& Petersen, extra staff modeling. . . . . . . . 85000

l.ewis \& Clark Exposition Co., contract for light-

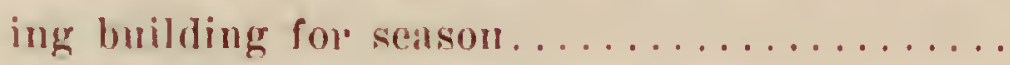
62000

Landscape gardening and floral embellishment.. 1,42350

Glarence lare, incidental expenses incurred as

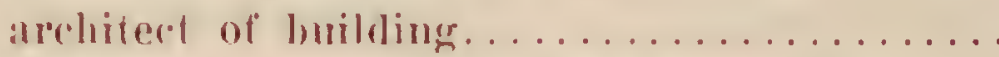

67730

Tull a Gibbs, furniture for state building...... $2,906 \quad 11$

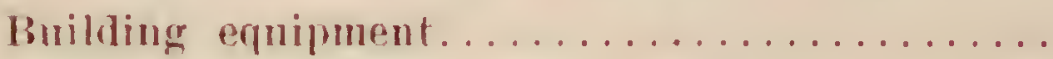
93146

Insurance on building amb contents.......... 45250

Amounts paid individual commissioners for personal expenses attending meetings of Commission and attending Fxposition at Portland, as follows:

Dr. Samuel B. Wirrl........ \$1,020 30

clarence Iace. . . . . . . . . . . 1,60340

17. D. Williams............ $\$ 2332$

Pratt A. Brown........... 1,45439

Henry Altman........... 1,10145

riarles R. Huntley......... 1,053 35

H. W. Williams. Treasurer, miscellaneons expenses, telegrams, postage, etc...........

Fxpenkes of oflicial delegation, including personal representatives of the Governor and legislative 
party, New York to Portland and return for

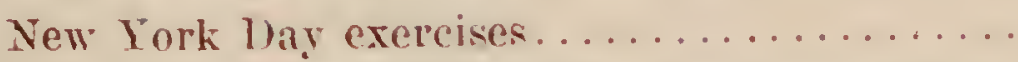

Bruno Pindat. for catering for the commission in. cluding State dinner to Lieutenant-Governor, recention on New York State Dar, dinner to President of Fxposition, dinner to the Covernor of Oregon, reception to the New York State Society of Oregon, reception to state commissioners and foreign representatives, dinner to officers of Sacajawea Society, meals of six commissioners and official delegation whilo in Portland

Amounts paid to employees for salaries, ete. as follows:

D. M. Ellis, executive officer.... $\$ 3.10000$ Seward H. Frencli. clerk and stenographer

8751011

Hugh .J. Kelly, assistanı.....

1.000000

E. J. Haddleton. attendant... 39000

Frank $W^{+}$. Stewart. attendant. 26000

C. R. Hotchkiss, attendant.... 27000

Albert Helmkamp, attendant... 16000

T. F. Carney, attendant...... 24800

Robert Mayes, page. so 00

Albert A. Hickman. bookknerer. $500(1)$

Mrs. B. Pindat. housekeepre... 2255100

Mary Harms. maid

Lizzic Vogel, maid..........

Heleu Noonan, maid........ 165 00

D. M. Ellis, miscellaneous expenses for commission mretings. 
Labor and material, unpacking, installing, taking down and repacking exhibit and storage...... \$701 01

Brandow Printing Co., stationery, engraving, etc. 32456

Printing and engraving at Portland.......... 48550

Decorations, music, etc., for official functions...

Carriage hire......................... $1,162 \quad 27$

Janitor service.......................

77050

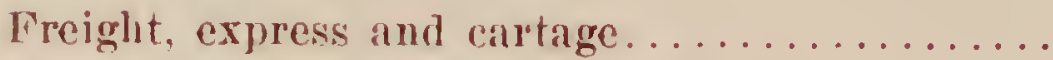
50780

Postage, telegrains, telephone service......... Supplies .......................... 2,96483

Miscellaneous ......................... 51211 84854 86814

Balance on hand................... 80613

$\$ 59,73455$

Crenits

Appropriation chapter 729 , Laws of $1904 \ldots \ldots$ $\$ 35,000 \quad 00$ Appropriation chapter 700 , Laws of $1905 . . .$. 20,00000 Amount received from Bruno Pindat for privilege of conducting restaurant in State building... 3,29685 Anount received from Paul Wessinger for furniture, chandeliers, awnings, screens and fixtures. Amount received from Victor Coxhead for

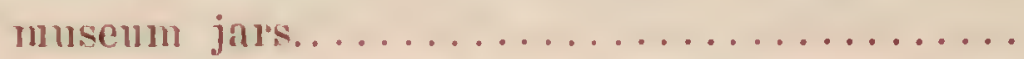
25000 Amount received for sale of miscellaneous efferts 



\section{Date Due}

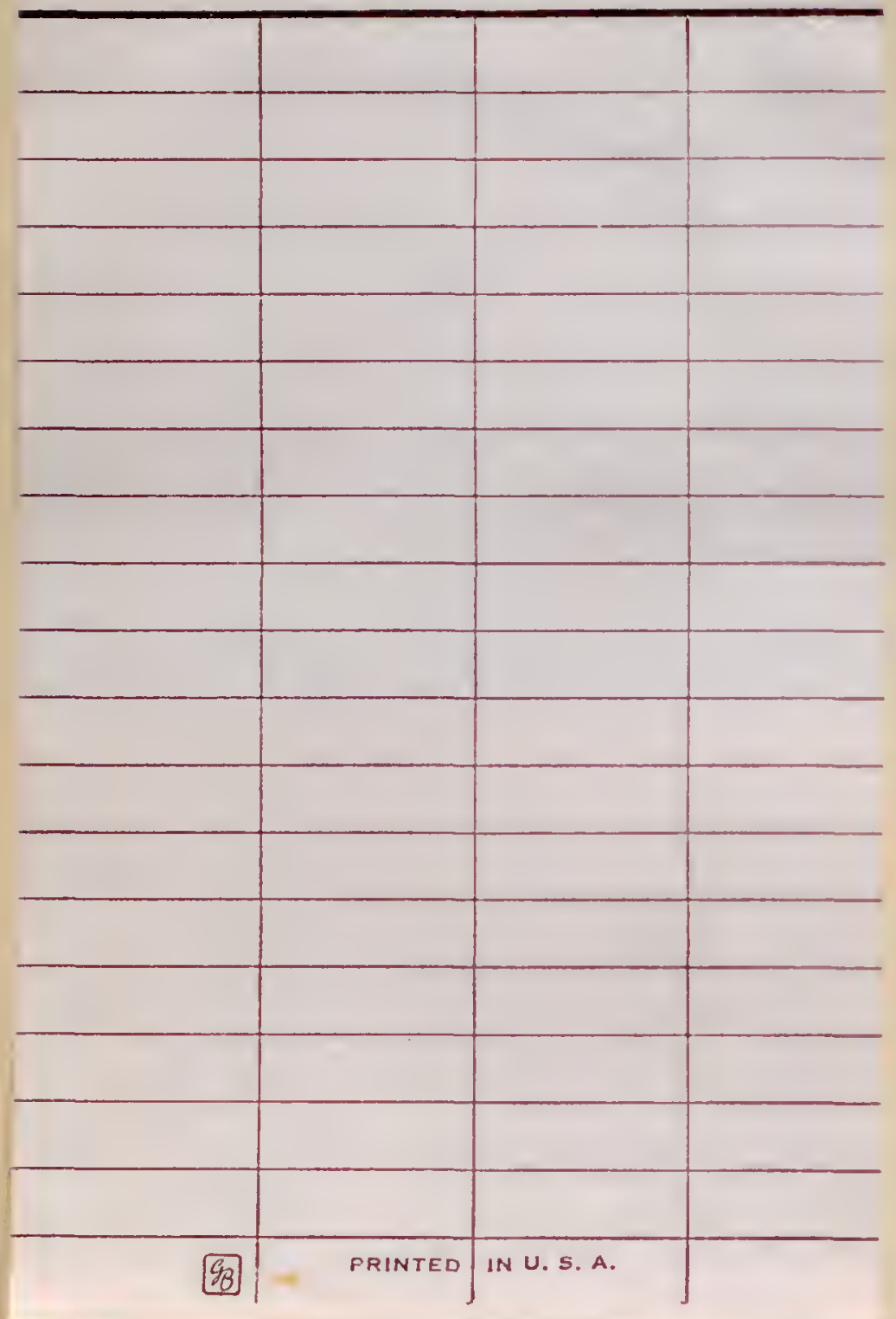


606

N532P3 New York (State) Lewis

AUTHOR and Clark exposition commission.

TITLE New York at the Lewis and Clark exposition. 30804

606

N532P3 New York (State) Lewis and Clark exposition commission. New York at the Lewis and Clark exposition. 

